Prepared in cooperation with the National Park Service

Simulation of Water-Table and Freshwater/Saltwater Interface Response to Climate-Change-Driven Sea-Level Rise and Changes in Recharge at Fire Island National Seashore, New York

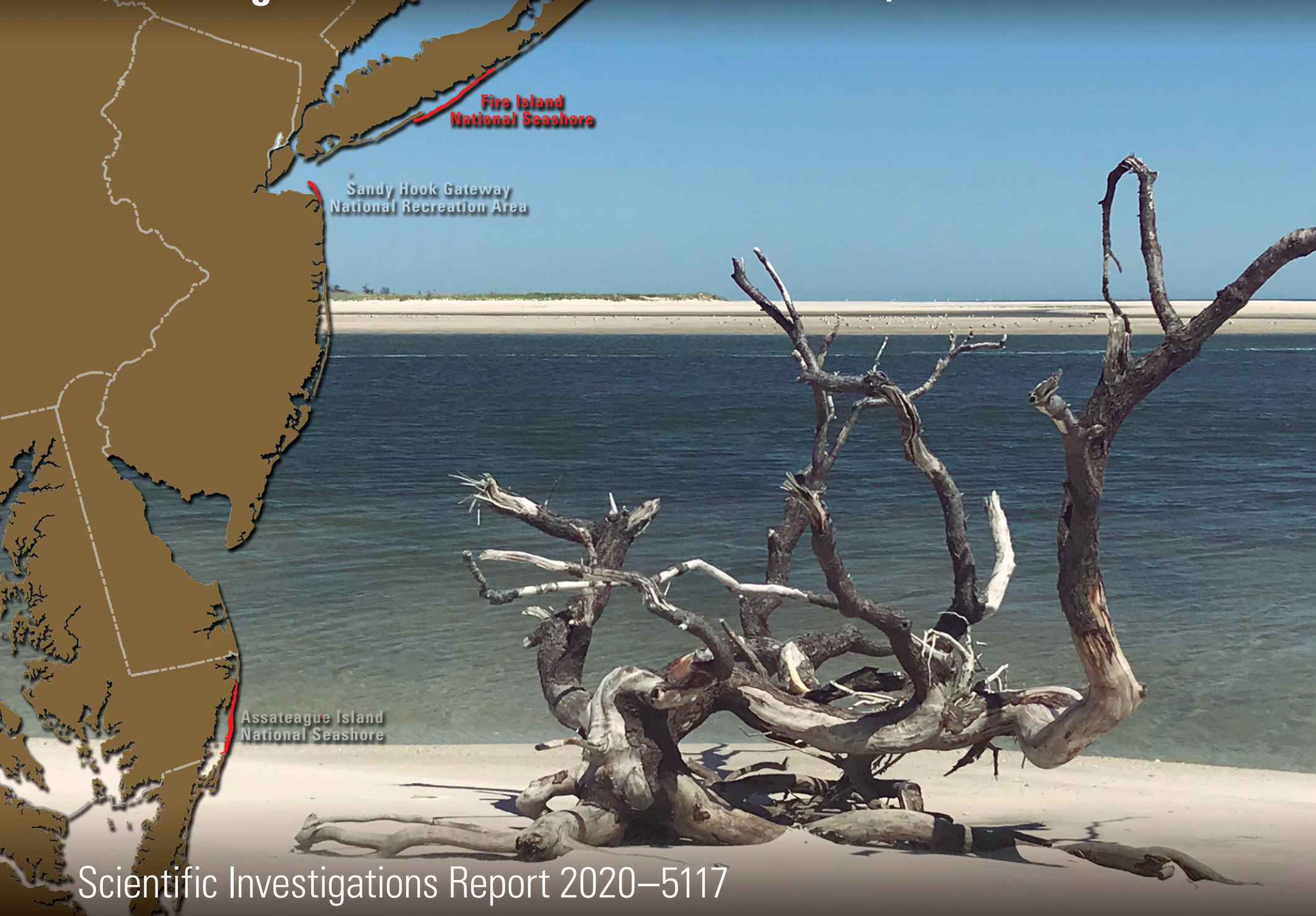

U.S. Department of the Interior U.S. Geological Survey 
Cover. Driftwood on the edge of a sandy beach, against the background of the Fire Island breach, with the edge of the breach in the background, Fire Island, New York. Photograph by Jennifer Miselis, U.S. Geological Survey. 


\section{Simulation of Water-Table and Freshwater/ Saltwater Interface Response to Climate-Change-Driven Sea-Level Rise and Changes in Recharge at Fire Island National Seashore, New York}

By Paul E. Misut and Sarken Dressler

Prepared in cooperation with the National Park Service

Scientific Investigations Report 2020-5117 


\section{U.S. Geological Survey, Reston, Virginia: 2021}

For more information on the USGS - the Federal source for science about the Earth, its natural and living resources, natural hazards, and the environment—visit https://www.usgs.gov or call 1-888-ASK-USGS.

For an overview of USGS information products, including maps, imagery, and publications, visit https://store.usgs.gov/.

Any use of trade, firm, or product names is for descriptive purposes only and does not imply endorsement by the U.S. Government.

Although this information product, for the most part, is in the public domain, it also may contain copyrighted materials as noted in the text. Permission to reproduce copyrighted items must be secured from the copyright owner.

Suggested citation:

Misut, P.E., and Dressler, S., 2021, Simulation of water-table and freshwater/saltwater interface response to climate-change-driven sea-level rise and changes in recharge at Fire Island National Seashore, New York: U.S. Geological Survey Scientific Investigations Report 2020-5117, 47 p., https://doi.org/10.3133/sir20205117.

Associated data for this publication:

Misut, P.E., 2021, MODFLOW-NWT model used to simulate water-table and freshwater/saltwater interface response to climate-change-driven sea-level rise and changes in recharge at the Fire Island National Seashore, New York: U.S. Geological Survey data release, https://doi.org/10.5066/P95TBIMW.

ISSN 2328-0328 (online) 


\section{Acknowledgments}

The authors are grateful for considerable data and technical insights provided by Jordan Raphael and members of the facilities and grounds department of the National Park Service. Mary Chepiga, Alison Gordon, Martha Watt, Glen Carleton, Emmanuel Charles, Chris Schubert, Brandon Fleming, Jeff Raffensperger, and Mat Pajerowski of the U.S. Geological Survey provided technical suggestions and assistance over many hours of meetings and conference calls. Richard Winston of the U.S. Geological Survey provided assistance with generating the groundwater-flow model archive and graphical-user interface. 



\section{Contents}

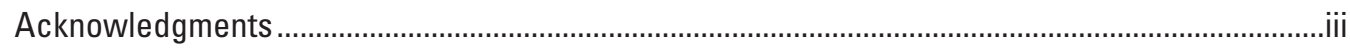

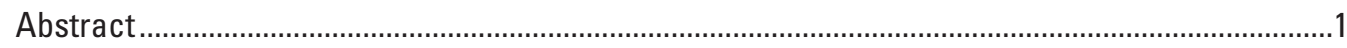

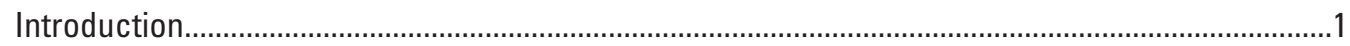

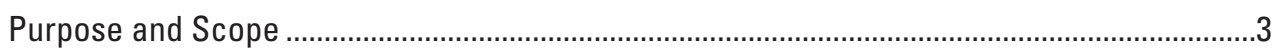

Related Studies and Previous Investigations ...........................................................................

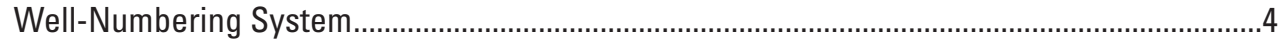

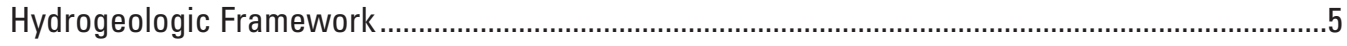

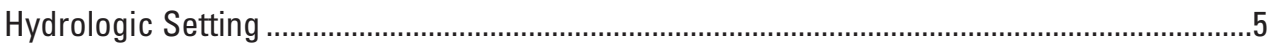

Freshwater/Saltwater Transition Zone...........................................................................

Results of Shallow Groundwater Flow System Simulations of Fire Island ......................................

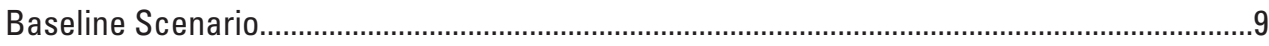

Depth to Water Table ........................................................................................................

Recharge and Discharge Areas .......................................................................................

Freshwater/Saltwater Interface ...........................................................................................17

Steady-State Simulation with Elevated Sea Levels and Varying Recharge ............................17

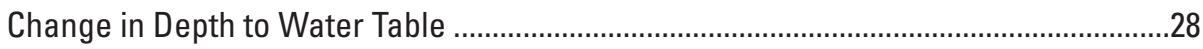

Recharge and Discharge Areas .....................................................................................28

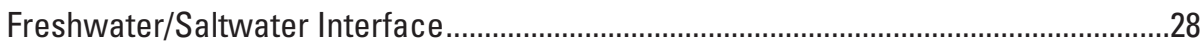

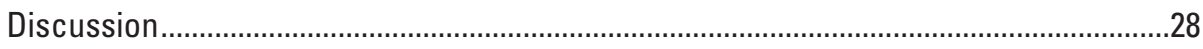

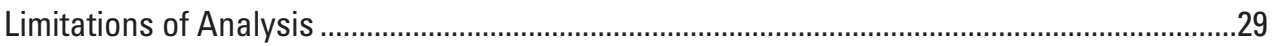

Use of Long-Term Monitoring To Assess Water Resources.....................................................30

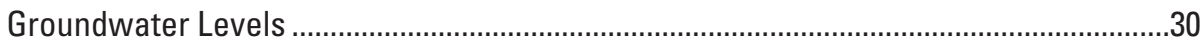

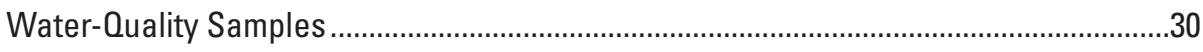

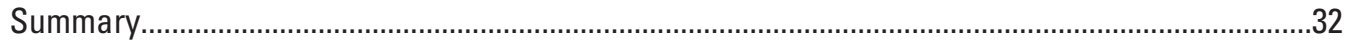

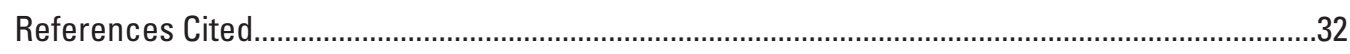

Appendix 1 Groundwater-Flow Model Design and Calibration .......................................................35 


\section{Figures}

1. Map showing location of the National Park Service study areas on Fire Island, New York, Assateague Island, Maryland, and Sandy Hook, New Jersey .........................2

2. Map showing location of Fire Island National Seashore, New York .................................3

3. Map showing location of observation wells on Fire Island, New York...............................4

4. Map showing locations of observation wells and vertical section $A-A^{\prime}$ and groundwater levels from 0ctober 31 to November 1, 2005, on Fire Island, New York; modified from Schubert (2010)

5. Cross section $A-A^{\prime}$ on Fire Island, New York, showing hydrogeologic units, freshwater/saltwater interface, and wells with screened intervals, water-table altitude, and groundwater levels on May 28, 2015.

6. Geophysical well logs from 2015 on Fire Island, New York. .8

7. Maps showing simulated water-table altitude for the baseline scenario for conditions in 2015 on Fire Island, New York.

8. Maps showing baseline scenario simulated $A$, depth to the water table, $B$, groundwater recharge rate, $C$, groundwater evapotranspiration rate, $D$, groundwater discharge rate to drains, and $E$, submarine groundwater discharge on Fire Island, New York.

9. Map showing baseline scenario simulated altitude of the freshwater/saltwater interface at the Fire Island National Seashore, New York.

10. Maps showing depth to water in 2015 at Sunken Forest holly parcels, simulated by the Seawater Intrusion package of the MODFLOW-NWT three-dimensional finite-difference groundwater model, at Sailors Haven on Fire Island, New York

11. Maps showing simulated change in $A$, depth to water, $B$, evapotranspiration, and $C$, depth to the freshwater/saltwater interface with 0.2-meter sea-level rise on Fire Island, New York.

12. Maps showing simulated change in $A$, depth to water, $B$, evapotranspiration, and $C$, depth to the freshwater/saltwater interface with 0.6-meter sea-level rise on Fire Island, New York.

13. Maps showing simulated change in A, depth to water, B, evapotranspiration, and $C$, depth to the freshwater/saltwater interface with 0.6-meter sea-level rise and 10-percent increase in recharge on Fire Island, New York

14. Maps showing potential long-term monitoring locations at Sailors Haven on Fire Island, New York

\section{Tables}

1. Generalized description of geologic and hydrologic units on Fire Island, New York........5

2. Simulated steady-state soil saturation conditions in 2015 in maritime holly forest areas of the National Park Service vegetation database on Fire Island, New York

3. Simulated flow rates to model boundaries for Fire Island, New York 


\section{Conversion Factors}

U.S. customary units to International System of Units

\begin{tabular}{lll}
\hline \multicolumn{1}{c}{ Multiply } & \multicolumn{1}{c}{ By } & \multicolumn{1}{c}{ To obtain } \\
\hline meter $(\mathrm{m})$ & 3.281 & foot $(\mathrm{ft})$ \\
square kilometer $\left(\mathrm{km}^{2}\right)$ & 0.3861 & square mile $\left(\mathrm{mi}^{2}\right)$ \\
cubic meter per day $\left(\mathrm{m}^{3} / \mathrm{d}\right)$ & 264.2 & gallon per day $(\mathrm{gal} / \mathrm{d})$ \\
millimeter per year $(\mathrm{mm} / \mathrm{yr})$ & 0.03937 & inch per year $(\mathrm{in} / \mathrm{yr})$ \\
\hline
\end{tabular}

\section{Datum}

Vertical coordinate information is referenced to the National Geodetic Vertical Datum of 1929 (NGVD 29) and the North American Vertical Datum of 1988 (NAVD 88).

Horizontal coordinate information is referenced to the North American Datum of 1983 (NAD 83).

Altitude, as used in this report, refers to distance above the vertical datum.

\section{Abbreviations}

$\begin{array}{ll}\text { CoNED } & \text { Coastal National Elevation Dataset } \\ \text { EVT } & \text { Evapotranspiration Package for MODFLOW } \\ \text { FEO } & \text { Freshwater Equivalent Head } \\ \text { GHB } & \text { General Head Boundary } \\ \text { LIDAR } & \text { Laser Imaging, Detection, and Ranging } \\ \text { MCL } & \text { Maximum Contaminant Level } \\ \text { MODFLOW } & \text { USGS Modular Hydrologic Model } \\ \text { NAVD } & \text { North American Vertical Datum } \\ \text { NGVD } & \text { National Geodetic Vertical Datum } \\ \text { NWT } & \text { Newton Formulation for MODFLOW-2005 } \\ \text { NPS } & \text { U.S. National Park Service } \\ \text { SEAWAT } & \text { Computer Program for Simulation of Three-Dimensional Variable-Density } \\ \text { SLR } & \text { Ground-Water Flow and Transport } \\ \text { SWI2 } & \text { Sea Level Rise } \\ \text { UCODE_2005 } & \text { Saltwater Intrusion Package for MODFLOW } \\ \text { USGS } & \text { U.S. Geological Survey } \\ \text { VDatum } & \text { Vertical Datum Tool }\end{array}$





\title{
Simulation of Water-Table and Freshwater/Saltwater Interface Response to Climate-Change-Driven Sea-Level Rise and Changes in Recharge at Fire Island National Seashore, New York
}

\author{
By Paul E. Misut and Sarken Dressler
}

\begin{abstract}
The fresh groundwater system at Fire Island National Seashore in New York is one of the natural resources that is most vulnerable to climate change; the various federally listed threatened or endangered species that live on Fire Island, including the piping plover, roseate tern shorebird, and seabeach amaranth may be affected by changes in the groundwater system. The U.S. Geological Survey, in cooperation with the National Park Service, developed a three-dimensional groundwater-flow model to simulate climate-change-related changes in depth to the water table and depth to freshwater/ saltwater interfaces on Fire Island. An existing SEAWAT three-dimensional variable-density groundwater flow and transport model was converted to a MODFLOW-NWT threedimensional finite-difference groundwater model with the Seawater Intrusion (SWI2) package and recalibrated using the UCODE_2005 automatic calibration software. The simulated groundwater divide was found to be skewed strongly toward the ocean shore in response to the modeled wave setup and tidal pumping overheight.

Effects of climate change include sea-level rise and changes in groundwater recharge rates. Sea-level rise scenarios included specified uniform steady states at 0.2-, 0.4-, and 0.6-meter increases above the 2015 level, applied to the existing topography. A high-recharge scenario was created by increasing 2015 recharge rates by 10 percent. Under all scenarios except the low-recharge scenario, the depth to the water table and the thickness of the unsaturated zone decreased. The thickness of the freshwater lens decreased under every scenario. Resulting maps were generated on a 25 -meter grid and indicate changes in areas where natural resources may be vulnerable because of projected climate changes.
\end{abstract}

\section{Introduction}

Global climate change is expected to contribute to a 0.2 - to 2 -meter $(\mathrm{m})$ sea-level rise by 2100 . Change in precipitation may result in reduced or increased groundwater recharge (Melillo and others, 2014). Barrier islands along the mid-Atlantic shoreline are susceptible to climate-driven changes that may threaten sensitive ecological habitats as well as public use.

The National Park Service (NPS) is evaluating the effects of global climate change on national parks and seashores and is developing strategies to adapt to changing climate (National Park Service, 2010). To aid the NPS in this goal, the U.S. Geological Survey cooperated with the NPS to study the response of groundwater resources in three national seashore areas in the mid-Atlantic to expected sea-level rise and changes in groundwater recharge associated with global climate change. The three mid-Atlantic NPS study areas are Fire Island National Seashore on Fire Island, New York; the Sandy Hook unit of the Gateway National Recreation Area in Sandy Hook, New Jersey; and Assateague Island National Seashore on Assateague Island, Maryland (fig. 1). These studies build on previous studies done on Fire Island by Schubert (2010) and on Assateague Island by Masterson and others (2013a, b).

Fire Island is approximately 60 kilometers $(\mathrm{km})$ long and $0.5 \mathrm{~km}$ wide and is bounded by the Great South Bay estuary to the north, the Atlantic Ocean to the south, Fire Island Inlet to the west, and Moriches Inlet to the east (fig. 2). The Fire Island National Seashore includes $42 \mathrm{~km}$ of shoreline on Fire Island. Accelerated sea-level rise, storms, rising temperatures, and changes in patterns of precipitation are all expected to drive considerable ecological changes.

Among the vulnerable resources are the island's fresh groundwater resources. The potential for climate-driven changes in the quantity and quality of the Fire Island National 


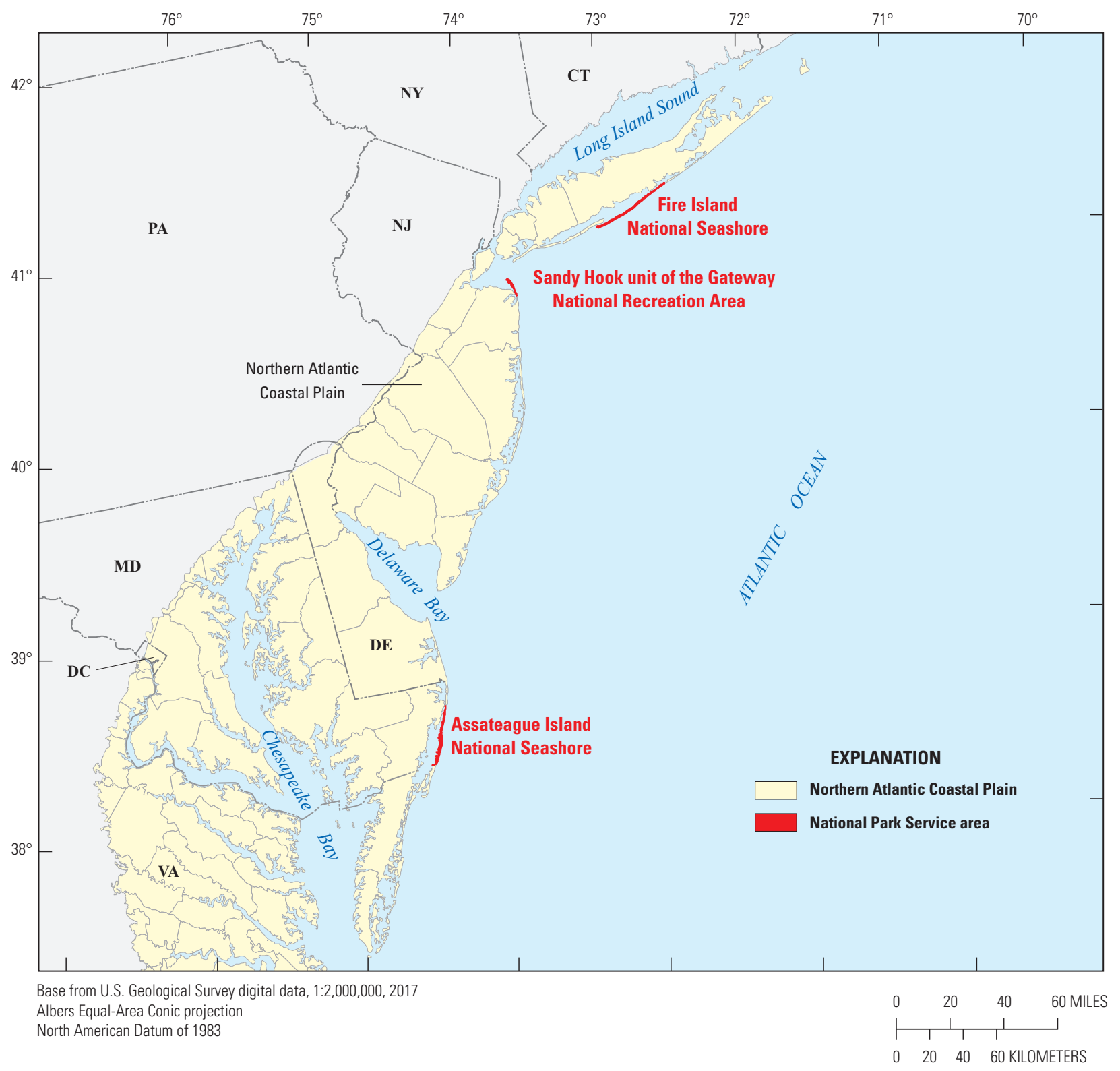

Figure 1. Map showing location of the National Park Service study areas on Fire Island, New York, Assateague Island, Maryland, and Sandy Hook, New Jersey.

Seashore groundwater resources threatens sensitive ecological habitats, including the Sunken Forest at Sailors Haven (fig. 2), an example of the rare maritime holly forest with a suite of dependent wildlife, such as amphibians, waterfowl populations, and invertebrates. Fire Island habitats include beach and dune, tidal wetland, freshwater emergent wetland, forested wetland, deciduous and evergreen successional forest, and other northeastern maritime habitats. Three federally listed threatened or endangered species are known to live on Fire Island: piping plover, roseate tern shorebirds, and seabeach amaranth (National Park Service, 2016).

A management goal for the Fire Island National Seashore is to increase the resiliency and capacity of coastal habitat and infrastructure to withstand storms and reduce the amount of damage caused by major storms. To facilitate management of ecohydrological effects and to increase understanding of the relation between sea-level rise and groundwater as it relates to the ecology of the maritime forests (especially the Sunken Forest) and other vegetated areas on the island, the NPS requires hydrologic information for the national seashores. Hurricane Sandy (also known as Superstorm Sandy because the storm transitioned to extratropical just before landfall) is the storm of record for Fire Island. In addition to the unique magnitude and track of Hurricane Sandy, sea-level rise contributed to the height of the water levels compared with previous storms because of the 2.8-millimeter per year ( $\mathrm{mm} / \mathrm{yr})$ average rate of sea-level rise in New York waters (New York State Department of Environmental Conservation, 2016). 


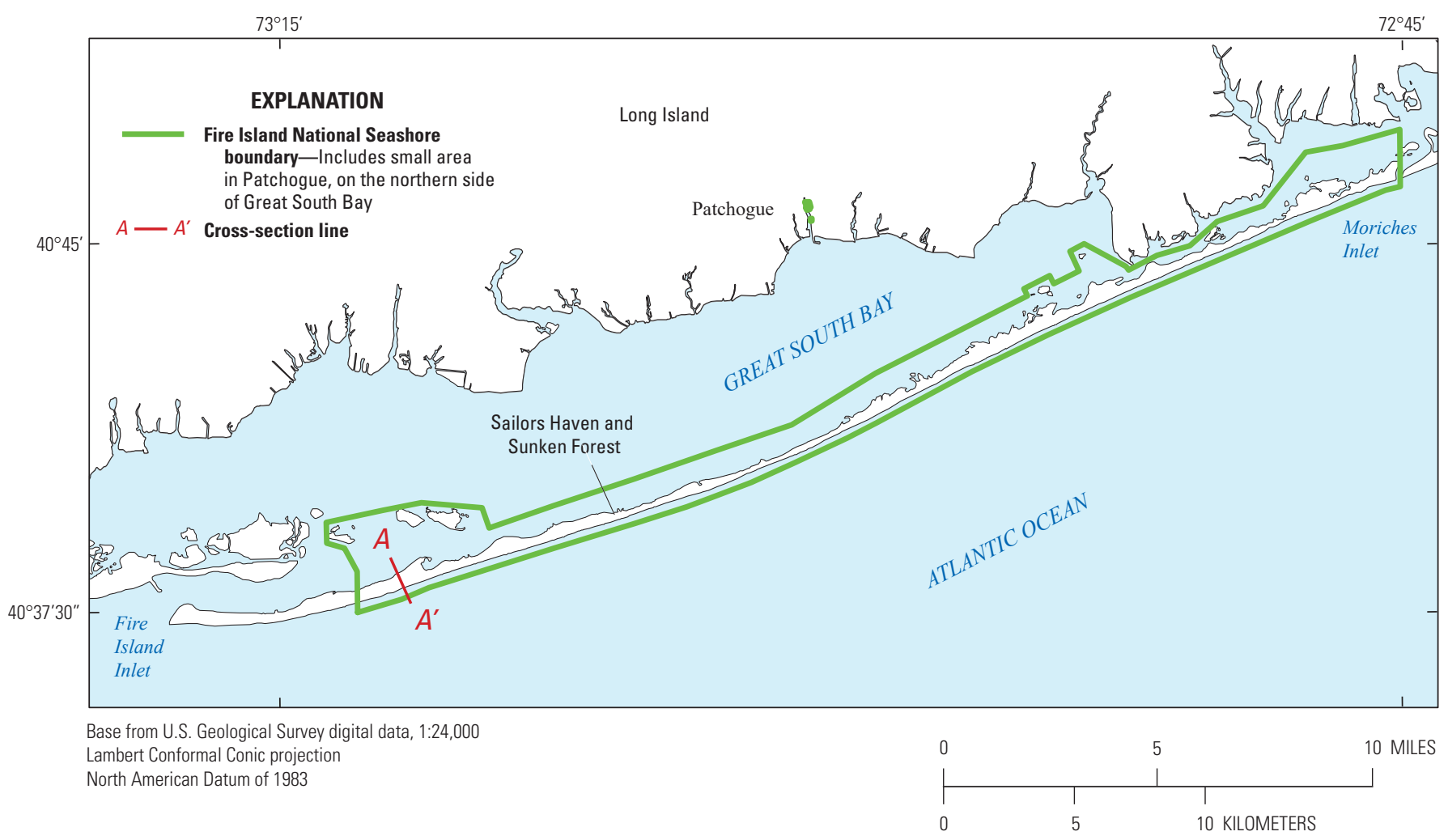

Figure 2. Map showing location of Fire Island National Seashore, New York.

This study evaluates the effects of sea-level rise and recharge change on the groundwater resources of Fire Island and how these changes may threaten sensitive ecological habitats. Six simulations are discussed: baseline present conditions, three sea-level rise scenarios, and two recharge scenarios. Because Fire Island lacks a defined surface-water drainage network, groundwater flow is the predominant pathway for freshwater movement on Fire Island, affecting both forested and wetland ecosystems. Understanding the possible effects of sea-level rise and changes in recharge on groundwater resources will allow the NPS to allocate scarce resources to best prepare for and manage climate-driven changes in the groundwater system and the subsequent effects on seashore ecosystems.

\section{Purpose and Scope}

The study had the following general objectives:

- Compile, collect, and analyze geologic, geomorphologic, and hydrologic data.

- Develop conceptual models of groundwater flow that represent the freshwater and saltwater flow systems.

- Develop numerical models of groundwater flow and conduct sensitivity and uncertainty analyses.
- Simulate expected climate-change scenarios including sea-level rise and precipitation change.

- Develop a long-term groundwater-monitoring plan.

This report documents data collection activities, describes the development and the results of groundwater flow modeling, and presents a framework for a monitoring plan. The source of the model input/output data used to support the simulations and hence the interpretations presented here is (Misut, 2021).

\section{Related Studies and Previous Investigations}

The Fire Island study was completed concurrently with studies of Sandy Hook (Carleton and others, 2021) and Assateague Island (Fleming and others, 2021). Previous studies of Fire Island (Schubert, 2010) and Assateague Island (Masterson and others, 2013a, b) included variable-density groundwater-flow models using SEAWAT (Langevin and others, 2007). Both studies incorporated hydrogeologic information into multilayer models that were calibrated to water-level data and simulated the shallow groundwater-flow system on the islands. The Fire Island study (Schubert, 2010) included groundwater-quality sampling to estimate nutrient loading from septic system discharge and calculated nitrogen loads in simulated groundwater discharge to back-barrier estuaries and the ocean but did not evaluate the response of the aquifer 
underlying Fire Island to sea-level rise. Masterson and others $(2013 a, b)$ evaluated the response of the fresh groundwater system on Assateague Island to sea-level rise magnitudes of $0.2,0.4$, and $0.6 \mathrm{~m}$. Their simulations are based on the assumption that, for all areas where the unsaturated zone thickness was less than the current conditions of the sea-level rise magnitude, discharge would either evaporate or run off into the saltwater bodies. As a result, the water table would not rise higher than the land surface, resulting in a thinner freshwater lens. Other previous investigations of the hydrology and hydrogeology of Fire Island include Miller and Frederick (1969), Smolensky and others (1989), and Leggette, Brashears, and Graham, Inc. (1996).

Raphael (2014) investigated tree mortality in the Sunken Forest on Fire Island and cited examples of coastal habitats experiencing unsaturated-zone thinning caused by sea-level rise. Sea-level rise has also influenced the increase in salinity within the groundwater and thinning of the unsaturated zone in many coastal habitats. This has changed the structure of the habitats and resulted in patterns of diminishing vegetation (Teskey and Hinckley, 1977; Hayden and others, 1995). Thinning of the unsaturated zone has also resulted in mortality of Pinus ellioti (slash pine) on Sugarloaf Key, Florida, and coastal hardwood-hemlock-button mangrove forests at Everglades National Park (Ross and others, 1994; Saha and others, 2011) and has affected vegetation in coastal areas of Virginia (Hayden and others, 1995). Thinning of the unsaturated zone can lead to increased salinity and accompanying flora mortality (Saha and others, 2011). Another cause of mortality is owing to freshwater drowning of the roots of plants that require a thicker unsaturated zone (Werner and Simmons, 2009; Terry and Chui, 2012; Masterson and others, 2013b; Holding and Allen, 2015). Freshwater wetland herbaceous species (for example, Polygonium hydropiperoides (Michx.) [swamp smartweed]) are colonizing depression sites in the Sunken Forest, perhaps because their tolerance of a thinner unsaturated zone caused by sea-level rise is allowing them to outcompete the extant vegetation (Jordan Raphael, National Park Service, written commun., 2016). Where sea-level rise has caused the freshwater/saltwater interface to move closer to the surface, shallow-rooted species may be unaffected, but deep-rooted species could be reaching brackish water, causing their fatalities. Erosion could also be playing a role by moving the shoreline closer to depressions in the Sunken Forest and, therefore, bringing the freshwater/saltwater interface closer to the surface (Ataie-Ashtiani and others, 1999; Werner and Simmons, 2009; Raphael, 2014).

\section{Well-Numbering System}

Observation wells included in this study (fig. 3) are numbered serially by county. The number is prefixed by the first letter of the county name; for example, well S6294 is in Suffolk County. Numbers are assigned in sequence by New York State as permits to drill were issued and have no relation to the location of wells within the county.

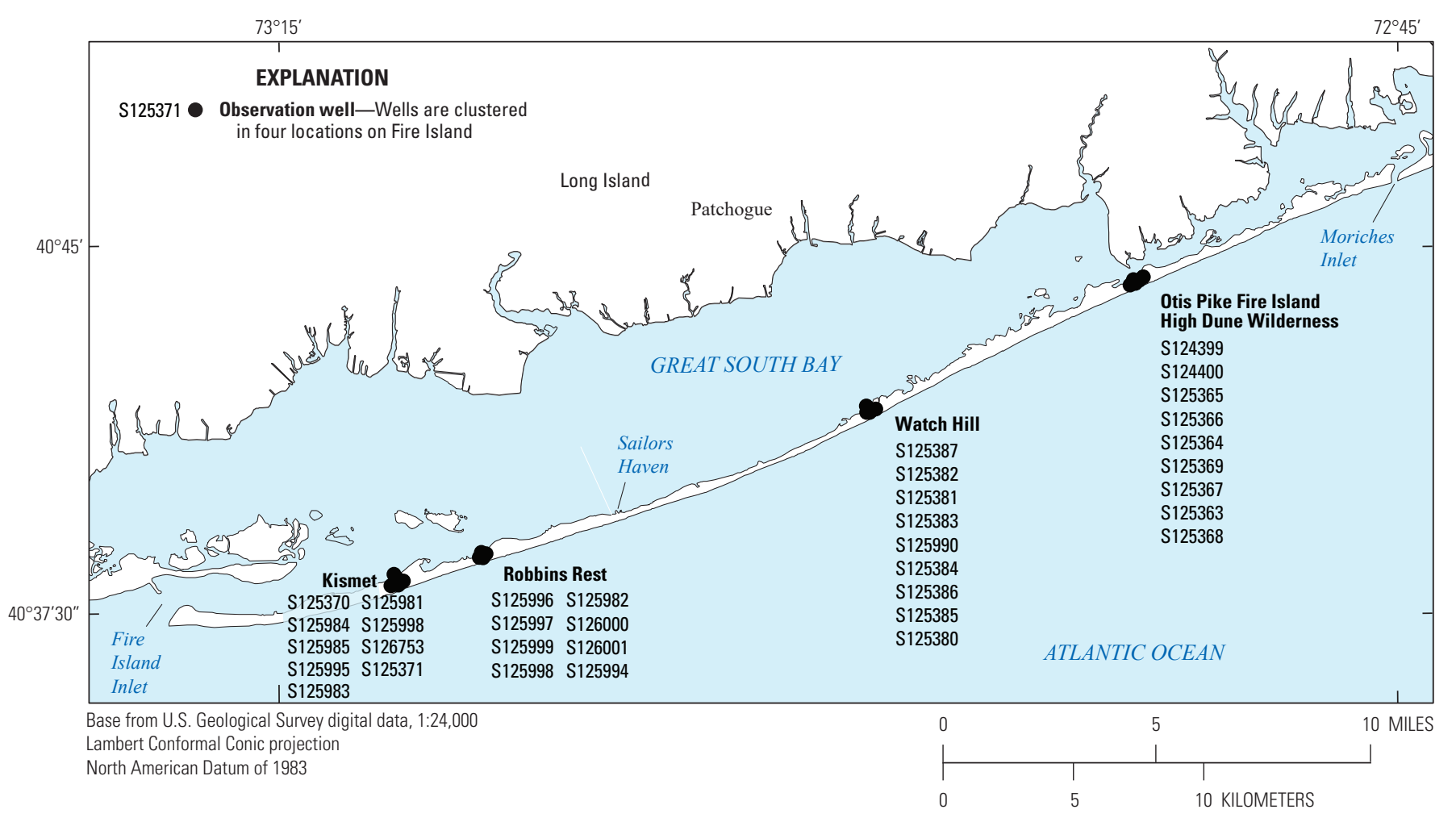

Figure 3. Map showing location of observation wells on Fire Island, New York. 


\section{Hydrogeologic Framework}

The groundwater system of Fire Island is controlled largely by the geologic and hydrologic characteristics of the area. The water table in the shallow, unconfined aquifer system above the Gardiners clay generally follows the local topography but is raised substantially on the ocean side compared with the back-bay side because of the pumping action of ocean waves. Shallow freshwater may exist from land surface to as deep as $8 \mathrm{~m}$ below the land surface. The water table often is less than $1 \mathrm{~m}$ below land surface. Beneath the low-density freshwater, there is saline groundwater. The altitude below sea level of the freshwater/saltwater interface is generally about 40 times the altitude of the water table above sea level.

The shallow geologic units of Fire Island are a sequence of Holocene surficial and Pleistocene glacial and nonglacial deposits underlain by Late Cretaceous coastal plain deposits (figs. 4 and 5; table 1). This study focuses on the shallow freshwater flow system extending through the Holocene and Pleistocene hydrogeologic units. The system is bounded laterally by marine surface waters and at depth by saline groundwater within Late Cretaceous coastal plain deposits.

\section{Hydrologic Setting}

The hydrologic setting of Fire Island includes groundwater recharge from precipitation, some inflow of saline waters across the ocean and bay floors, and discharge of both fresh and saline waters to inland surface-water features and to the ocean and bay. The recharge rate is controlled mainly by the precipitation rate. Discharge rates are controlled in part by leakance characteristics of boundaries and by the hydraulic gradient across boundaries. The hydraulic gradient is generally related to the local mean sea level but has been augmented by the effects of breaking waves (wave setup and setdown) and asymmetrical tidal infiltration and seepage (tidal pumping); this creates a condition referred to as water-table overheight (Nielsen, 1990), which was calculated for Fire Island by Schubert (2010). Water levels along a representative cross section (figs. 4 and 5) indicated the presence of a mounded water table with a maximum of about $1 \mathrm{~m}$ above mean sea level near the ocean shore. The water table mounding configuration is owed to the greater effects of wave setup and tidal pumping and the resulting water-table overheight along the ocean shore to the south compared with the bay shore to the north.

Infiltration of precipitation and return flow of publicsupply water through septic systems (in unsewered areas) creates groundwater recharge. Most recharge takes place during fall, winter, and spring because evapotranspiration in summer

Table 1. Generalized description of geologic and hydrologic units on Fire Island, New York.

[Table is modified from Schubert (2010). Descriptions of Upper Cretaceous deposits modified from Jensen and Soren (1974); descriptions of selected Pleistocene deposits modified from Jensen and Soren (1974) and Doriski and Wilde-Katz (1983); descriptions of selected Holocene deposits modified from Jones and Schubel (1980) and LoCicero (2006)]

\begin{tabular}{|c|c|c|c|}
\hline Age & Geologic unit & Hydrologic unit & Generalized description of deposits \\
\hline \multirow[t]{3}{*}{ Holocene } & $\begin{array}{l}\text { Barrier island and } \\
\text { shelf sands }\end{array}$ & $\begin{array}{l}\text { Barrier island and } \\
\text { shelf sands }\end{array}$ & Fine to medium sand \\
\hline & Seagrass beds & Seagrass beds & $\begin{array}{l}\text { Inorganic sediments consist mostly of fine sand and silt with some } \\
\text { medium sand }\end{array}$ \\
\hline & Estuarine mud & Estuarine mud & Clay and silt with some fine sand \\
\hline \multirow[t]{2}{*}{ Pleistocene } & Upper outwash & $\begin{array}{l}\text { Upper glacial } \\
\text { aquifer }^{1}\end{array}$ & $\begin{array}{l}\text { Brown, fine to coarse sand, locally with some gravel and streaks of silt } \\
\text { and clay }\end{array}$ \\
\hline & "20-foot" clay & “20-foot" clay & $\begin{array}{l}\text { Grayish-green to gray clay that contains a few sand and silt beds, and } \\
\text { has same fossil content as Gardiners clay }\end{array}$ \\
\hline Upper Cretaceous & Monmouth Group & $\begin{array}{l}\text { Monmouth green- } \\
\text { sand }\end{array}$ & $\begin{array}{l}\text { Greenish to black clay, silt, and sand containing large amounts of } \\
\text { glauconite and lignite }\end{array}$ \\
\hline
\end{tabular}

${ }^{1}$ Coarse-grained deposits of post-Cretaceous age on Long Island are commonly considered one hydrologic unit and are referred to as the upper glacial aquifer. 


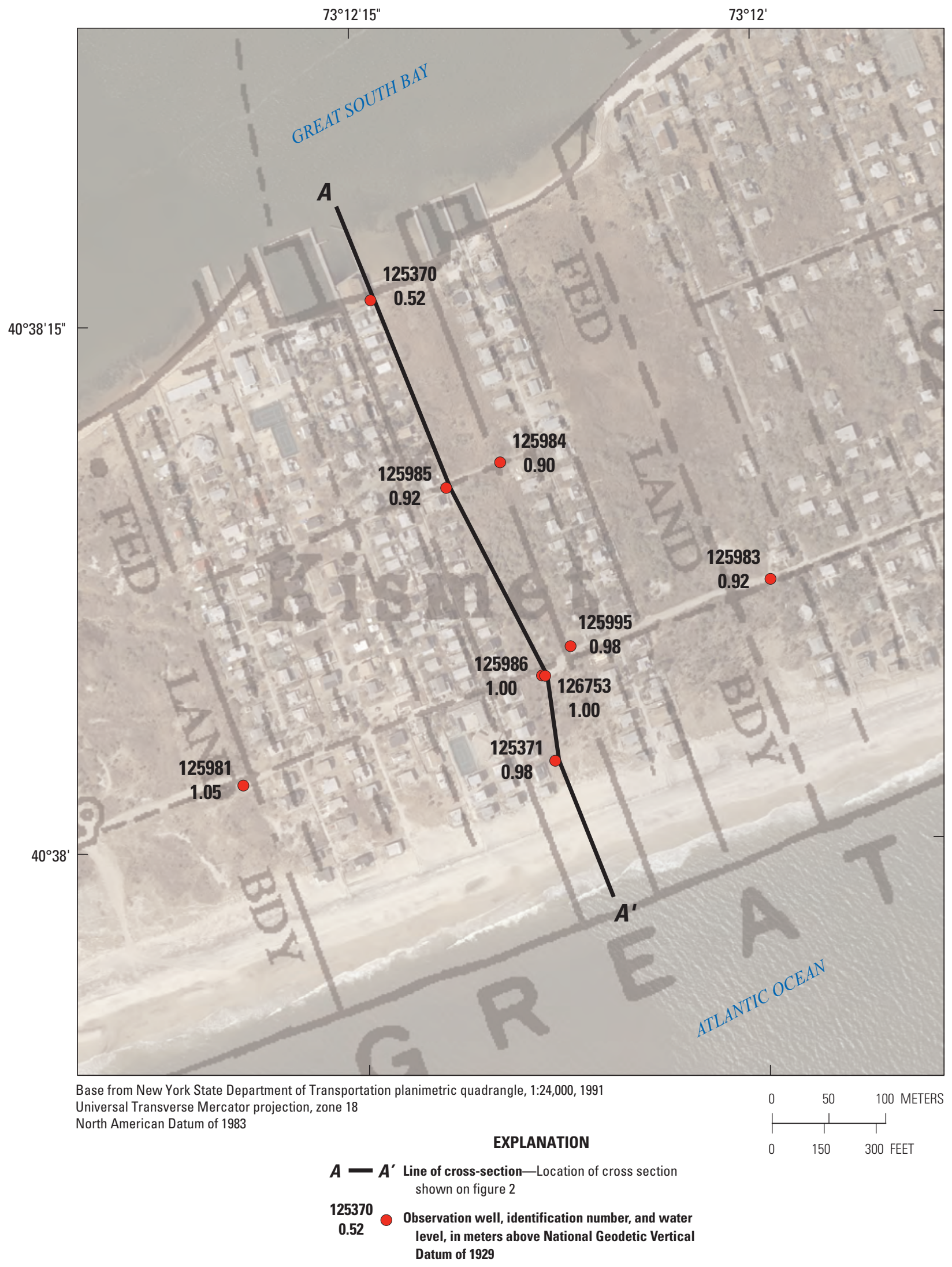

Figure 4. Map showing locations of observation wells and vertical section $A-A^{\prime}$ and groundwater levels from 0 ctober 31 to November 1, 2005, on Fire Island, New York; modified from Schubert (2010). 
SOUTHEAST

$A$

DEPTH, IN

METERS

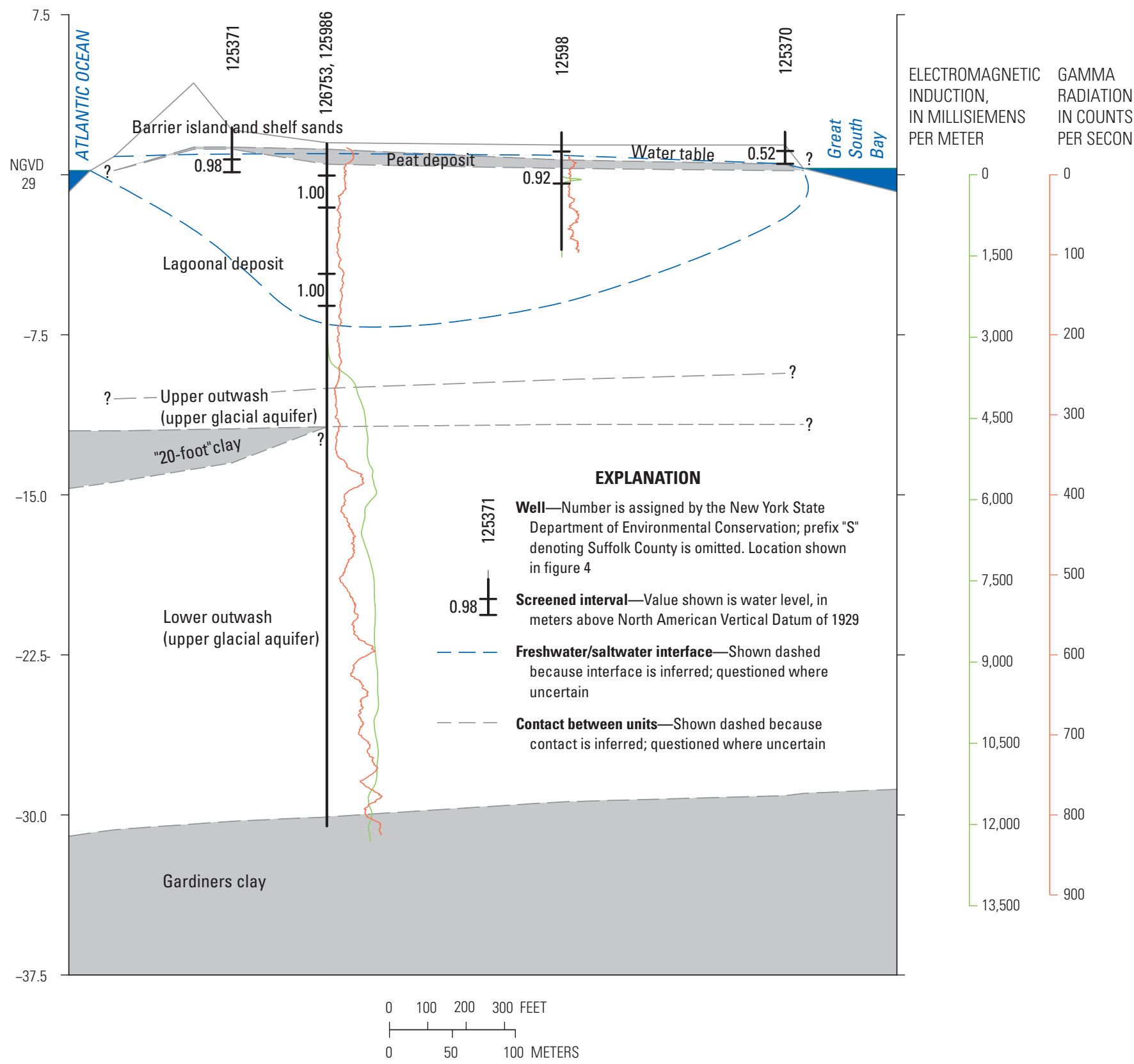

VERTICAL SCALE GREATLY EXAGGERATED

Figure 5. Cross section A-A' on Fire Island, New York, showing hydrogeologic units, freshwater/saltwater interface, and wells with screened intervals, water-table altitude, and groundwater levels on May 28, 2015; modified from Schubert (2010). Altitude in this cross section is relative to the National Geodetic Vertical Datum of 1929 (NGVD 29). 
decreases recharge during that season. About 81 percent of the land area on Fire Island is recreational and open space, including the Otis Pike Fire Island High Dune Wilderness designated in 1980; 12 percent of the island is residential, and the remaining 7 percent includes all other uses. Most public-supply water on Fire Island is ultimately discharged to the water table, primarily through onsite wastewater disposal systems and, to a lesser extent, as leakage from the water-distribution system. The remaining water is lost as consumptive use.

Groundwater is generally discharged as seepage across the seabed into marine surface waters (nearshore underflow), seepage through confining layers into saline groundwater (subsea underflow), or pond and wetland evapotranspiration. The only fresh surface-water features on the island are groundwater-fed ponds, which are surface-water exposures at the water table. Pond flow-through may occur as shallow groundwater discharge to the pond at the upgradient side coupled with pond-water recharge at the downgradient side.

Well pumpage is highly concentrated during the summer season, and most domestic plumbing systems are winterized. Public water supply is derived solely from wells that pump groundwater from deep regional aquifers that are not in hydraulic connection with the shallow freshwater lens that is the focus of this study. A small number of private and NPS houses that are not served by the public water-supply systems derive drinking water independently from the shallow flow system.

\section{Freshwater/Saltwater Transition Zone}

In the water-table aquifer, the transition zone from freshwater to saltwater is 5 to $20 \mathrm{~m}$ thick and is the result of complex mixing processes, including diffusion, density-driven flow, daily tidal fluctuations, weekly freshwater recharge events, monthly tidal-range changes, periodic storm-driven salt spray and overwash, and long-term response to sea-level rise. For this study, the freshwater/saltwater transition zone is delineated as a sharp interface at a total dissolved solids concentration of 29 parts per thousand, about that of ocean water. The altitude below sea level of the freshwater/saltwater interface is generally about 40 times the altitude of the water table above sea level. The location of the freshwater/saltwater interface was estimated at cross sections through analyses of geophysical logs described in Schubert (2010) and relogged in 2015 as part of this study (fig. 6).
A. Well S125990 (Watch Hill)

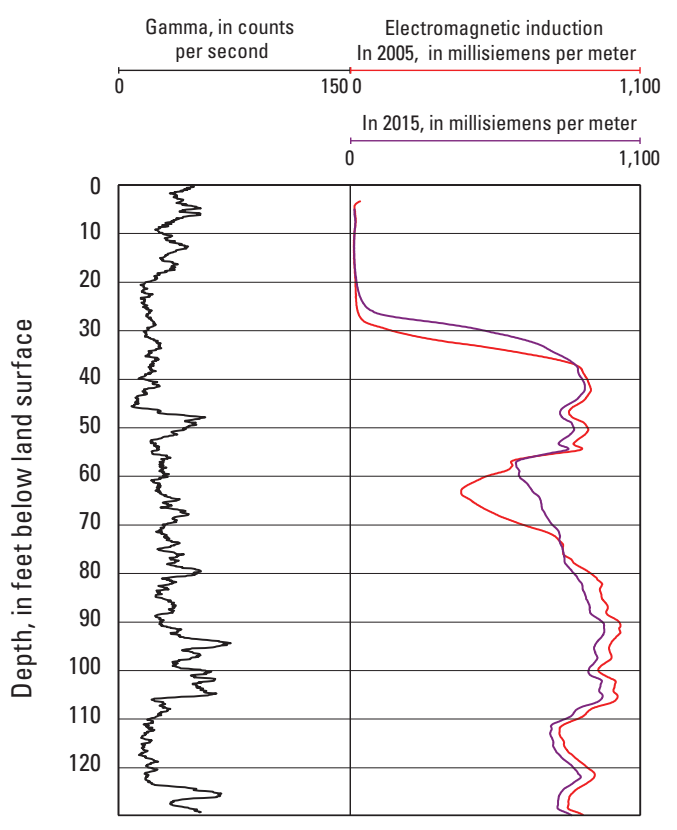

\section{B. Well S126000 (Robins Rest)}

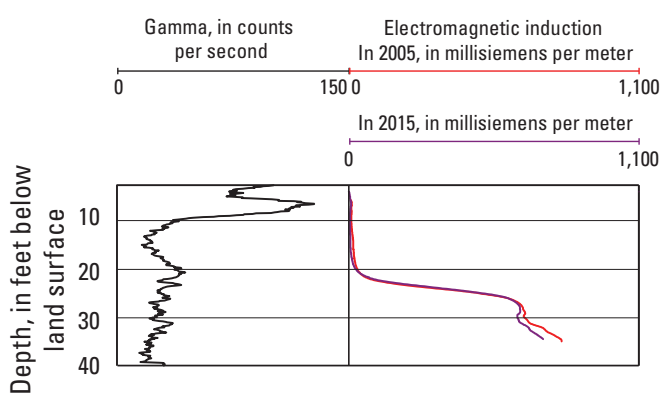

\section{Well S126753 (Kismet)}
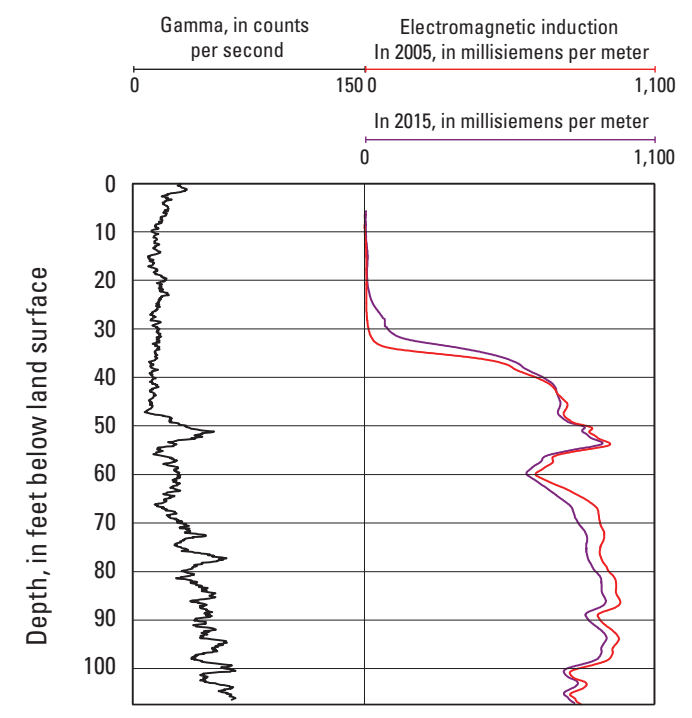

Figure 6. Geophysical well logs from 2015 on Fire Island, New York. Location of wells shown in figure 3. 


\section{Results of Shallow Groundwater Flow System Simulations of Fire Island}

Groundwater flow on Fire Island was simulated using a numerical groundwater flow model (Misut, 2021) to evaluate the effects that sea-level rise and changes in recharge would have on the depth to water below land surface and on the depth of the freshwater/saltwater interface. The design and calibration of the model is described in appendix 1 . The Newton-Raphson formulation for MODFLOW-2005 (MODLFOW-NWT) was used to improve the solution of the unconfined groundwater flow problem (Niswonger and others, 2011). The baseline scenario model was calibrated to average groundwater levels in 2015 and mean sea level from 1981 to 2001; the scenario is described in the "Baseline Scenario" section of this report. Water-level altitude, depth to water below land surface, and depth to the freshwater/saltwater interface associated with sea-level rise of $0.2,0.4$, and $0.6 \mathrm{~m}$ and a 10 -percent increase and decrease in recharge are compared with those of the baseline scenario to calculate changes associated with possible future conditions. These scenarios are based on the Intergovernmental Panel on Climate Change projections for 2000 to 2100 (Intergovernmental Panel on Climate Change, 2008).

The effects of sea-level rise and changes in recharge are evaluated by comparing the water-level altitude of the baseline scenario with each of the five future scenarios and calculating changes in depth to water below land surface and depth to the freshwater/saltwater interface. Also, the model evaluates changes in the groundwater-discharge boundaries of groundwater evapotranspiration, land-surface seeps (drains), and submarine discharge.

\section{Baseline Scenario}

The baseline scenario uses a sea level boundary equal to the 1981-2001 mean sea level of the North American Vertical Datum of 1988 and calibrated recharge rate and other parameters as described in appendix 1 . This sea level boundary has fallen below the present [2015] sea level altitude (but has not exceeded the sea-level rise scenario of $0.2 \mathrm{~m}$ described in the "Steady-State Simulation With Elevated Sea Levels and Varying Recharge" section of this report). The simulated water-level altitude on Fire Island ranges from mean sea level to a maximum of about $1 \mathrm{~m}$ (fig. 7). The asymmetry of the water-table surface caused by the water-table overheight boundary along the Atlantic Ocean coastline is evident. The simulated water table exhibits variations in response to local differences in recharge rates associated with different land covers (sand or minimally vegetated, forested, shrub, developed, or wetland) or groundwater evapotranspiration.

\section{Depth to Water Table}

Although the simulated water table is smooth and has modest horizontal gradients $(0.001$ meter per meter or less over most of the land area), the simulated depth to water varies substantially over short distances owing to changes in land surface topography, which includes primary dunes, wetlands, and secondary dunes (fig. $8 \mathrm{~A}$ ). The water table is at land surface in some interior closed-depression emergent wetlands but is also more than $4 \mathrm{~m}$ below land surface beneath secondary dunes that are as little as $100 \mathrm{~m}$ away from some of the emergent wetlands. The water-table altitude simulated with the MODFLOW-NWT three-dimensional finitedifference groundwater model (fig. 7) was subtracted from the USGS Coastal National Elevation Database (CoNED) 1-m light detection and ranging (lidar) (Danielson and others, 2016; U.S. Geological Survey, undated) data that were used to represent land-surface altitude to generate the simulated depth to water (fig. $8 A$ ). Where values are positive, the value represents the thickness of the unsaturated zone. Where values are negative, the model cell is fully saturated, there is no depth to water, and groundwater is actively discharging to evapotranspiration boundary conditions or to surface-waterrelated boundaries. The magnitude of negative values indicates the relative magnitude of the discharge rate, depending on boundary condition type and parameter values. The Seawater Intrusion (SWI2) package was used to simulate depths to the freshwater/saltwater interface (fig. 9).

The maritime holly forest at Sailors Haven (fig. 10) is an ecological zone sensitive to a thinning unsaturated zone (Raphael, 2014). When soil in depressions in the forest becomes completely saturated, the result can be die-off of holly trees. The simulated percentage of completely saturated areas within the holly forest are identified in the NPS Fire Island vegetation map (table 2; National Park Service, 2002, map code 6376). Area identifiers 3761 to 3903 are within the Sunken Forest designated areas; other parcels are elsewhere at Fire Island National Seashore.

\section{Recharge and Discharge Areas}

Freshwater flows into the groundwater system in recharge areas as well as seawater may flow into the groundwater system along the Atlantic Ocean coastline because of the watertable overheight boundary. Flow out of the system occurs as submarine groundwater discharge or, where the water table is at or near land surface, as groundwater evapotranspiration or groundwater drains (discharge to land-surface drainage). The variable rates of recharge are estimated by Schubert (2010) and shown in figure $8 B$. The average rate of recharge over the island is about 2 cubic meters per day $\left(\mathrm{m}^{3} / \mathrm{d}\right)$ per model cell.

Groundwater is discharged as evapotranspiration where the water table is above the estimated extinction (minimum) depth for evapotranspiration. For the majority of land area, the evapotranspiration rate is zero because the water table is below the evapotranspiration extinction depth (fig. 8C). For 


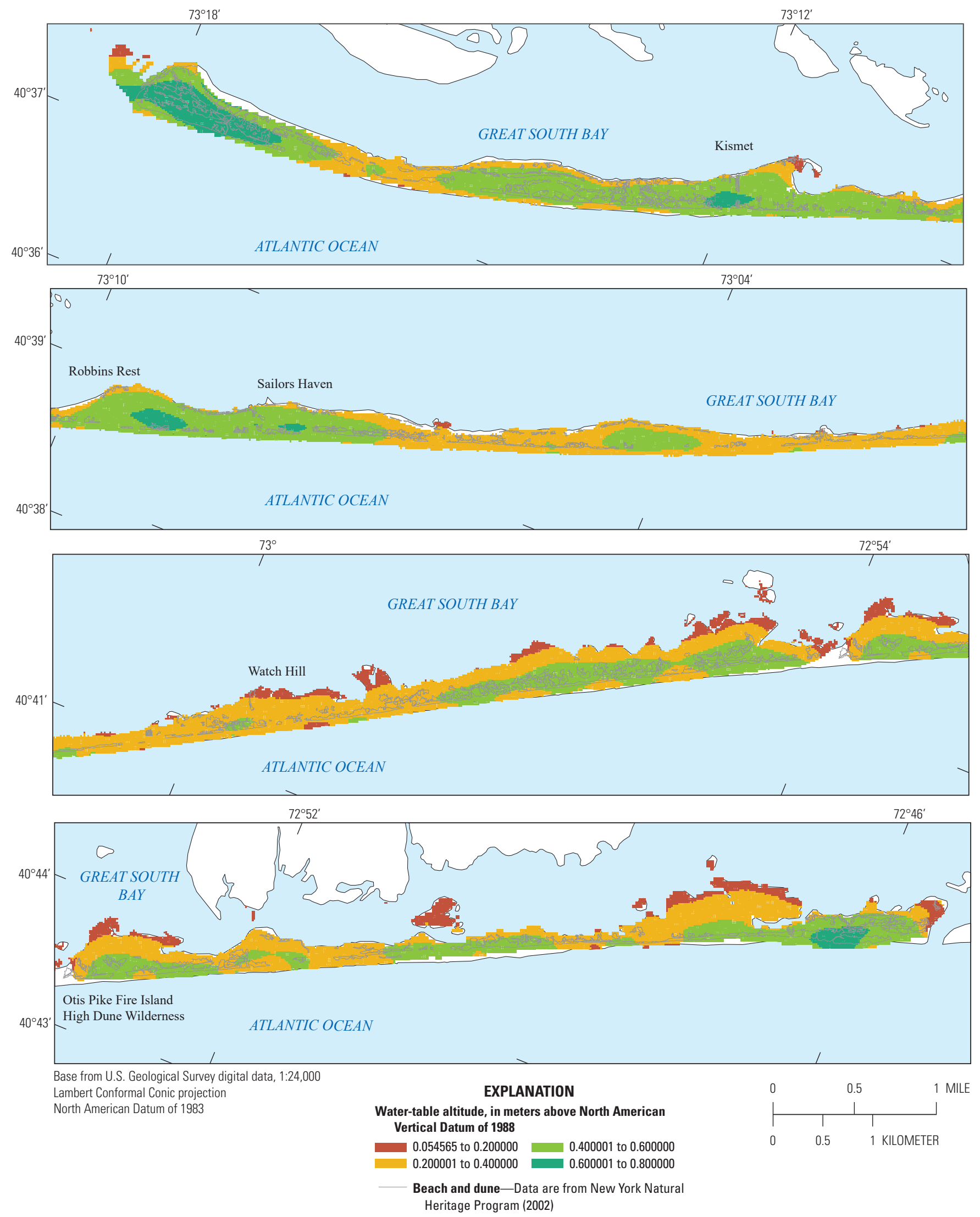

Figure 7. Maps showing simulated water-table altitude for the baseline scenario for conditions in 2015 on Fire Island, New York. Model grid shown in figure 1.2. Maps from top to bottom represent Fire Island from west to east, respectively. 


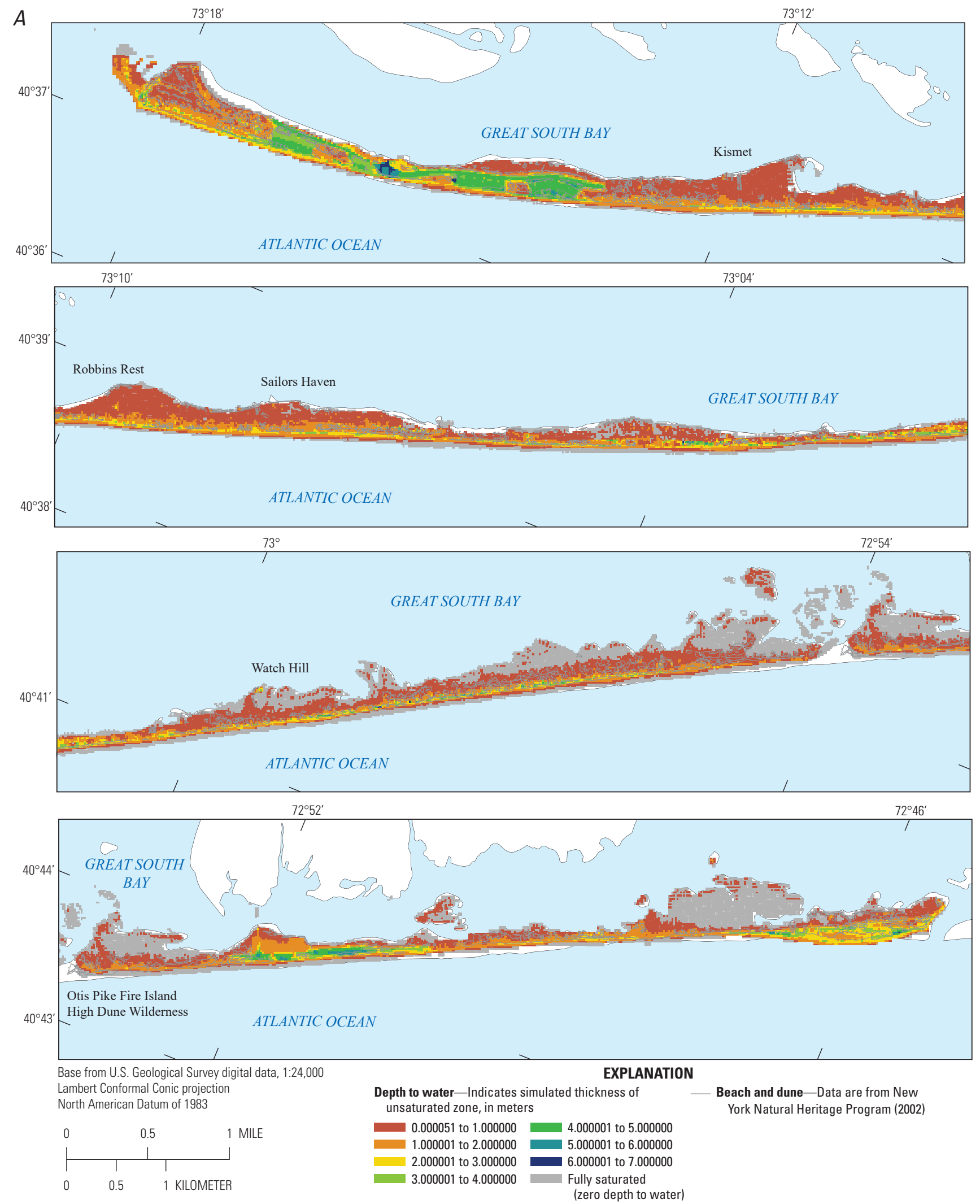

Figure 8. Maps showing baseline scenario simulated $A$, depth to the water table, $B$, groundwater recharge rate, $C$, groundwater evapotranspiration rate, D, groundwater discharge rate to drains, and E, submarine groundwater discharge on Fire Island, New York. Model grid shown in figure 1.2. Maps from top to bottom represent Fire Island from west to east, respectively. 


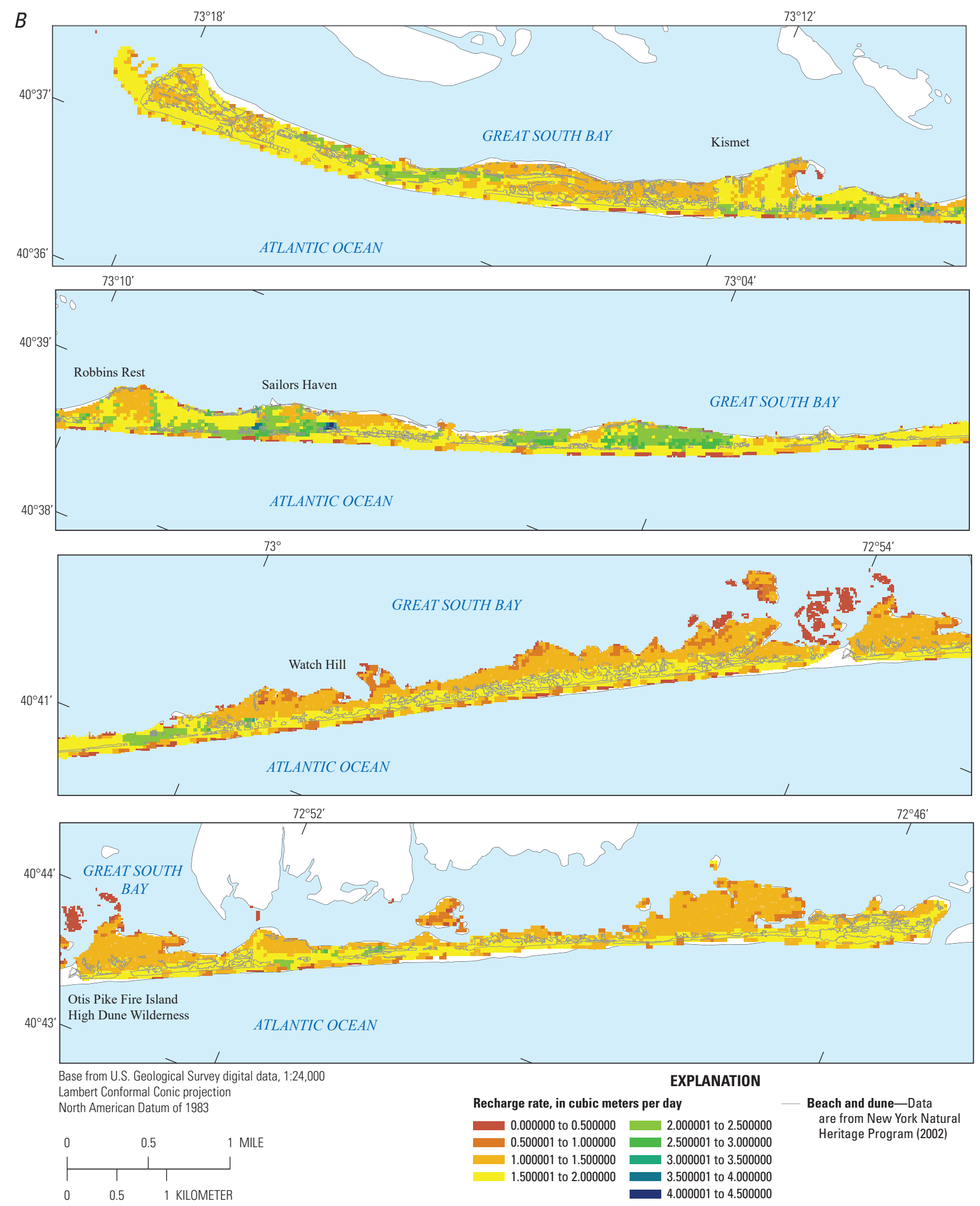

Figure 8. - Continued 

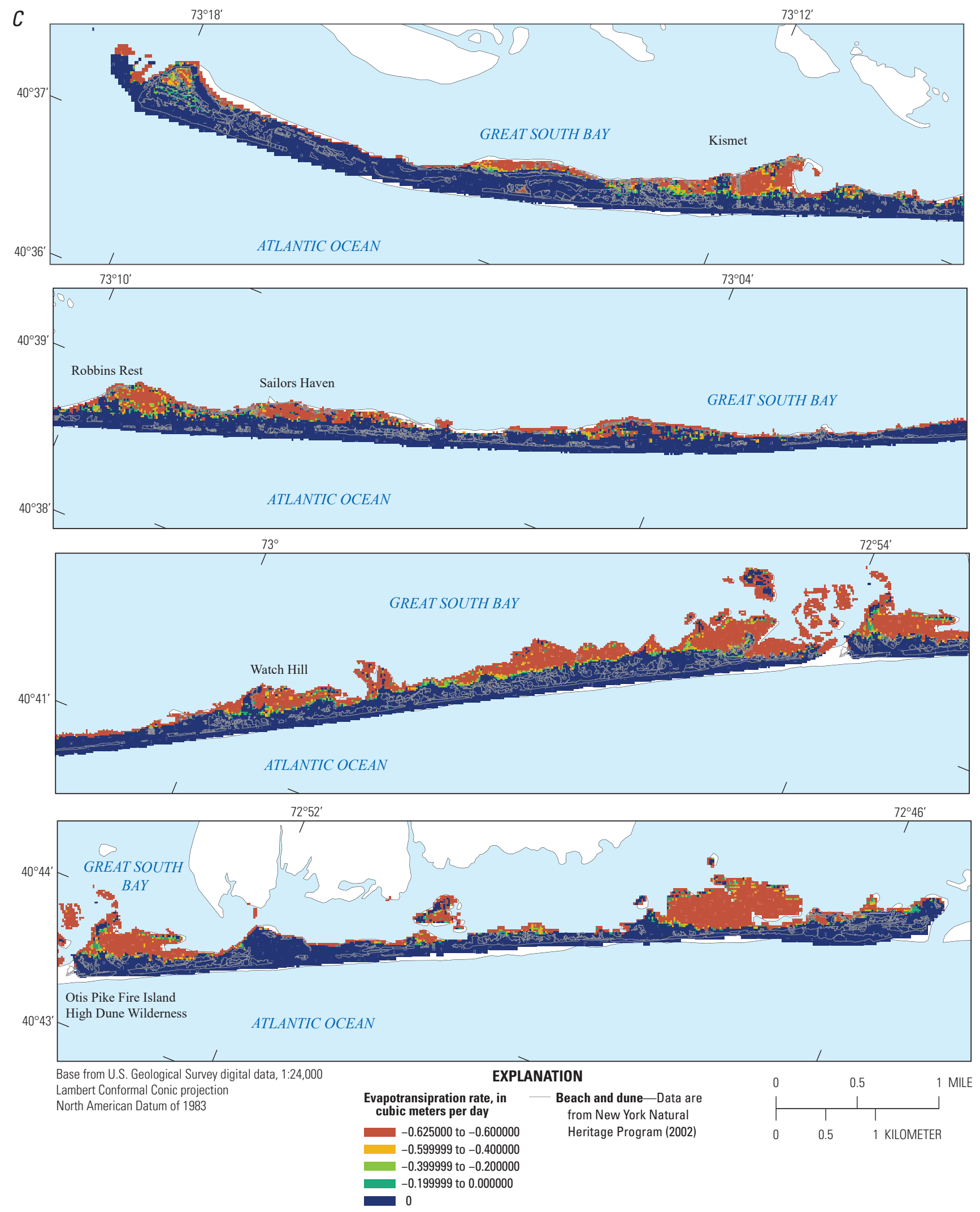

Figure 8. - Continued 


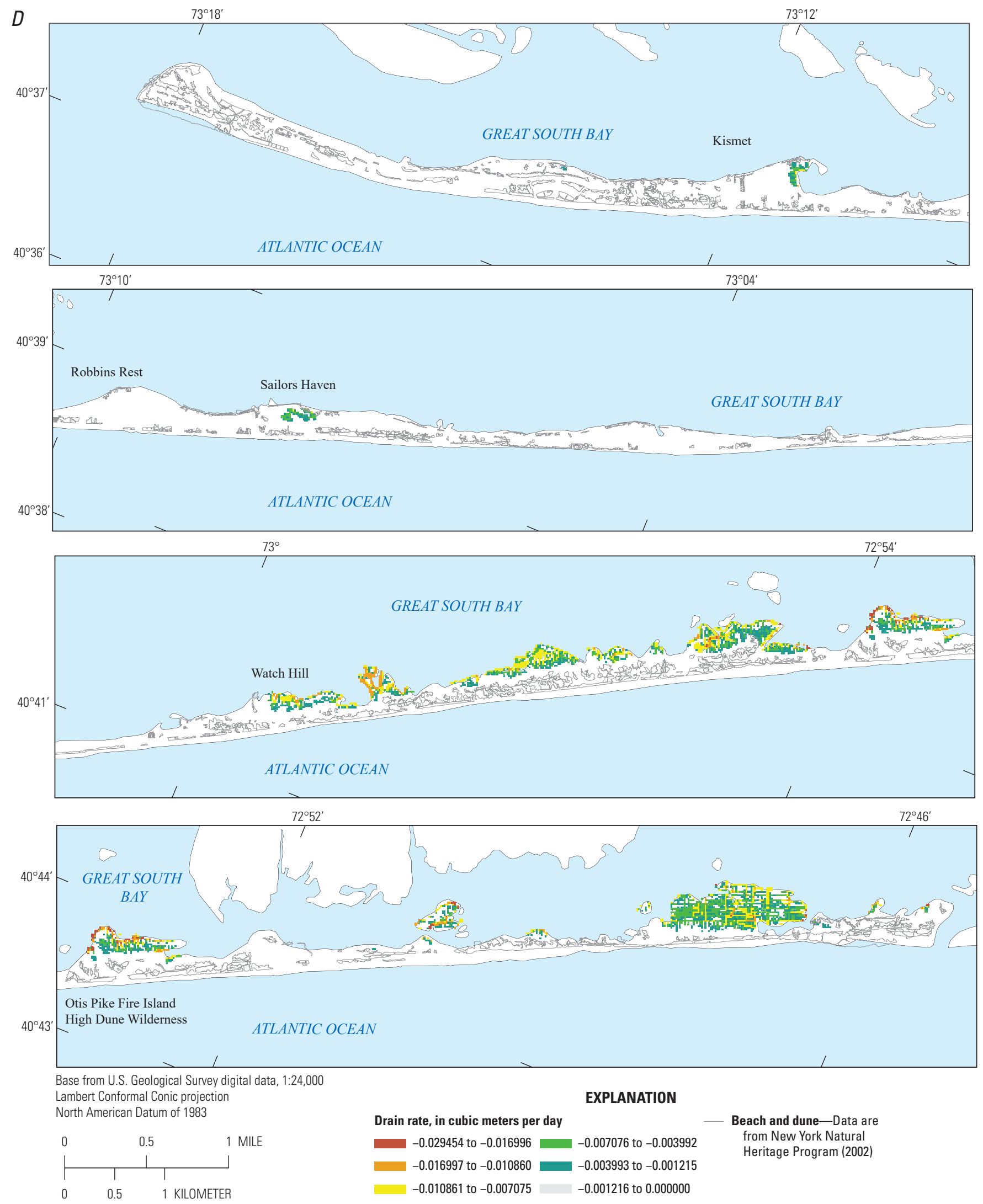

Figure 8. - Continued 


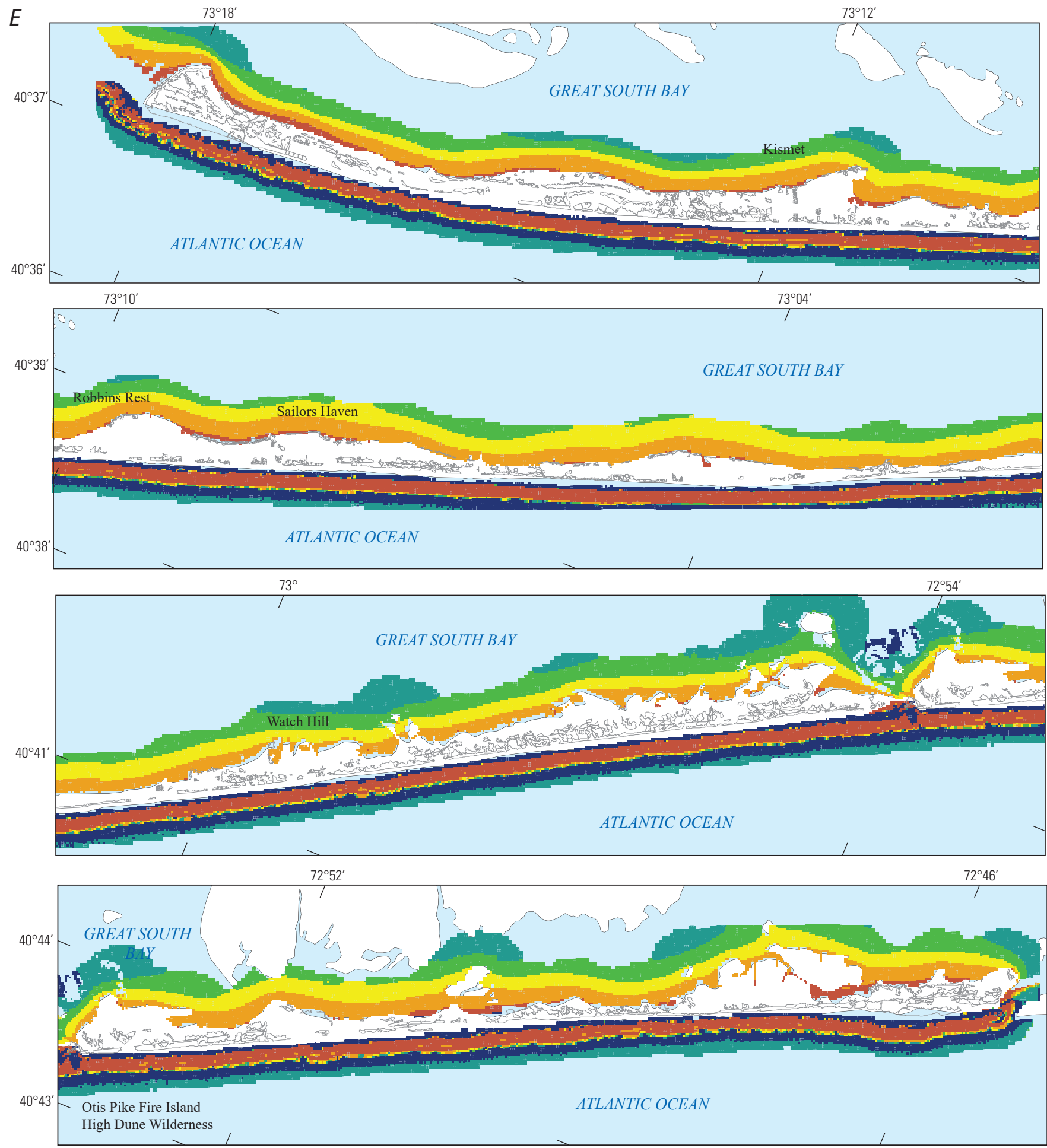

Base from U.S. Geological Survey digital data, 1:24,000 Lambert Conformal Conic projection North American Datum of 1983

EXPLANATION

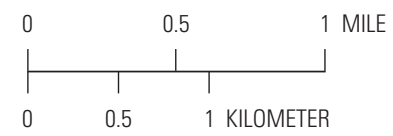

Figure 8. -Continued
Discharge of groundwater from land to sea (submarine), in cubic meters per day

-142.116989 to $-1.536023 \quad-0.338439$ to -0.152941

-1.536024 to $-0.639075-0.152942$ to 0.073017

-0.639076 to $-0.338438 \square 0.073018$ to 124.157715
Beach and dune-Data are

from New York Natural Heritage Program (2002) 

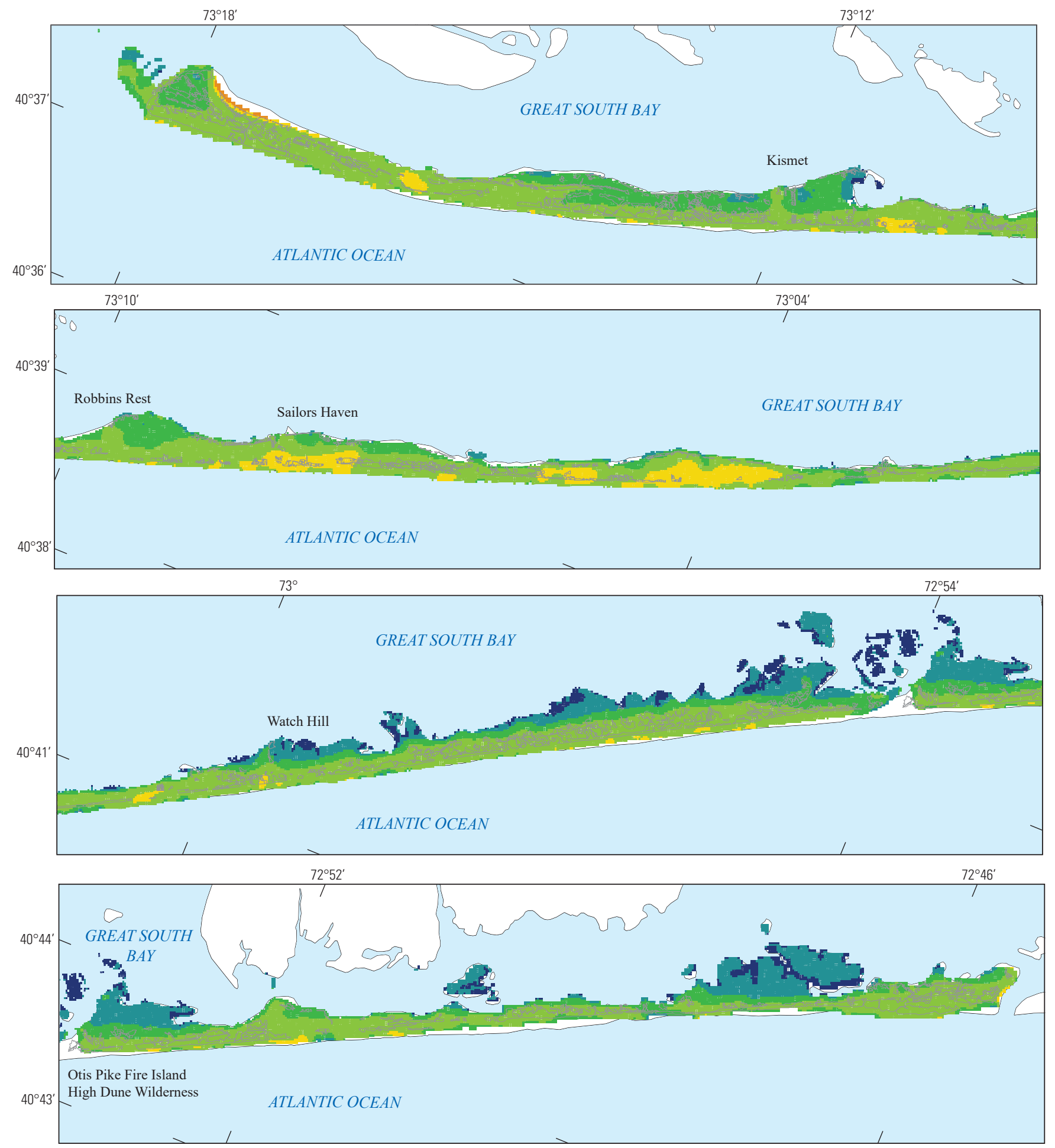

Base from U.S. Geological Survey digital data, 1:24,000 Lambert Conformal Conic projection North American Datum of 1983
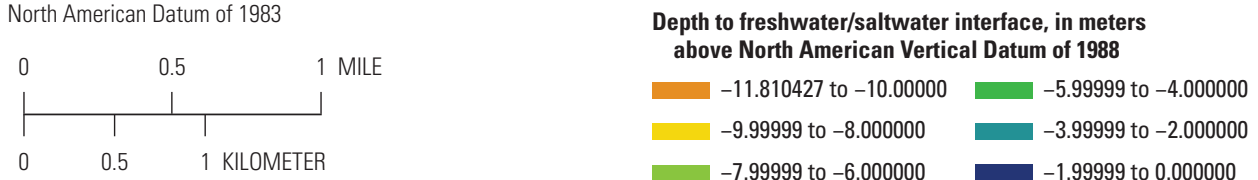

Figure 9. Map showing baseline scenario simulated altitude of the freshwater/saltwater interface at the Fire Island National Seashore, New York. Model grid shown in figure 1.2. Maps from top to bottom represent Fire Island from west to east, respectively. 
Table 2. Simulated steady-state soil saturation conditions in 2015 in maritime holly forest areas of the National Park Service vegetation database on Fire Island, New York.

[Area identifier is defined in National Park Service (2002), map code 6376. $\mathrm{m}^{2}$, square meters]

\begin{tabular}{ccccc}
\hline Area identifier & $\begin{array}{c}\text { Total area, } \\
\text { in } \mathbf{~ m}^{\mathbf{2}}\end{array}$ & $\begin{array}{c}\text { Saturated area, } \\
\text { in } \mathbf{~ m}^{\mathbf{2}}\end{array}$ & $\begin{array}{c}\text { Unsaturated area, } \\
\text { in } \mathbf{~ m}^{\mathbf{2}}\end{array}$ & $\begin{array}{c}\text { Percentage of } \\
\text { total area that is } \\
\text { saturated }\end{array}$ \\
\hline 3761 & 4,166 & 44 & 4,122 & 1 \\
3775 & 12,862 & 419 & 12,443 & 3 \\
3785 & 7,361 & 142 & 7,218 & 2 \\
3792 & 21,767 & 213 & 21,555 & 1 \\
3813 & 35,036 & 1 & 35,035 & 0 \\
3866 & 8,312 & 225 & 8,087 & 3 \\
3868 & 4,994 & 738 & 4,256 & 15 \\
3874 & 4,107 & 104 & 4,003 & 3 \\
3881 & 12,010 & 1,447 & 10,563 & 12 \\
3903 & 847 & 0 & 847 & 0 \\
\hline
\end{tabular}

areas where the simulated water table is above the land surface altitude, evapotranspiration is the maximum possible rate per model cell at $0.625 \mathrm{~m}^{3} / \mathrm{d}$. Where the water table is below the land surface but above an evapotranspiration extinction depth, the evapotranspiration rate is modeled as a linear function of the water-table depth below land surface. Groundwater is discharged to seeps in the baseline scenario only along the northern coastline of Fire Island (fig. 8D) along Great South Bay. Discharge to seeps occurs at an average rate of $0.003 \mathrm{~m} 3 / \mathrm{d}$.

Groundwater that does not discharge at or near land surface to seeps or evapotranspiration leaves the shallow flow system as submarine groundwater discharge (fig. $8 E$ ). Because of the water-table overheight boundary along the Atlantic Ocean coast, saltwater may enter the groundwater system in a narrow strip along the coast (localized submarine recharge) in the simulated offshore area. Submarine groundwater is discharged elsewhere, with the highest rates closer to shore and less discharge farther from shore.

\section{Freshwater/Saltwater Interface}

The variable-density numerical modeling code SWI2 (Bakker and others, 2013) in conjunction with MODFLOWNWT (Niswonger and others, 2011) simulates the freshwater/ saltwater transition zone as a sharp interface at a user-specified seawater density. In the case of Fire Island, a dimensionless density value of 0.022 corresponds to a total dissolved solids concentration of 29 parts per thousand (the salinity of ocean water), calculated as the difference between seawater and freshwater density divided by the freshwater density (Bakker and others, 2013). The simulated altitude of the freshwater/ saltwater interface is similar to that indicated by the available observations (comparison of values given in appendix 1). The simulated altitude of the freshwater/saltwater interface is generally at depths suggested by the Ghyben-Herzberg principle, which states that the depth to the freshwater/saltwater interface (fig. 9) is directly proportional to the height of the freshwater table above mean sea level. This shows the altitude of the interface to be a sufficient baseline from which to evaluate changes in depth to the interface with variations in sea-level rise or differences in recharge.

\section{Steady-State Simulation with Elevated Sea Levels and Varying Recharge}

Four hypothetical future scenario simulations are reported here: sea-level rise of $0.2,0.4$, and $0.6 \mathrm{~m}$ and 10 percent increase in recharge during sea-level rise of $0.6 \mathrm{~m}$. The sea-level rise scenario models have saltwater-boundary heads greater than the baseline scenario. Predicting future changes in the shape of the shoreline from erosion or deposition was beyond the scope of this study. The water-table overheight boundary along the Atlantic Ocean coastline of Fire Island was not altered other than to raise it by scalar values of $0.2,0.4$, and $0.6 \mathrm{~m}$ (figs. 11 and 12 ; the results for the $0.4-\mathrm{m}$ sea-level rise are similar to other results and are not illustrated). For the 10-percent increase in recharge scenario, the only change to the $0.6 \mathrm{~m}$ sea-level rise model was the uniform increase in the various recharge rates applied (fig. 13). Two additional hypothetical future recharge scenarios were also simulated but not reported here owing to similar findings with the reported increased recharge scenarios: 10 percent increase and 10 percent decrease in recharge during present conditions. The increase in heads owing to the 10 percent increase in recharge during present conditions is similar in magnitude to the increase in heads owing to the 10 percent increase in recharge during $0.6 \mathrm{~m}$ sea-level rise. The decrease in heads owing to the 10 percent decrease in recharge during present conditions is similar in magnitude (but opposite in sign) to the increase in heads owing to the 10 percent increase in recharge during $0.6 \mathrm{~m}$ sea-level rise. 


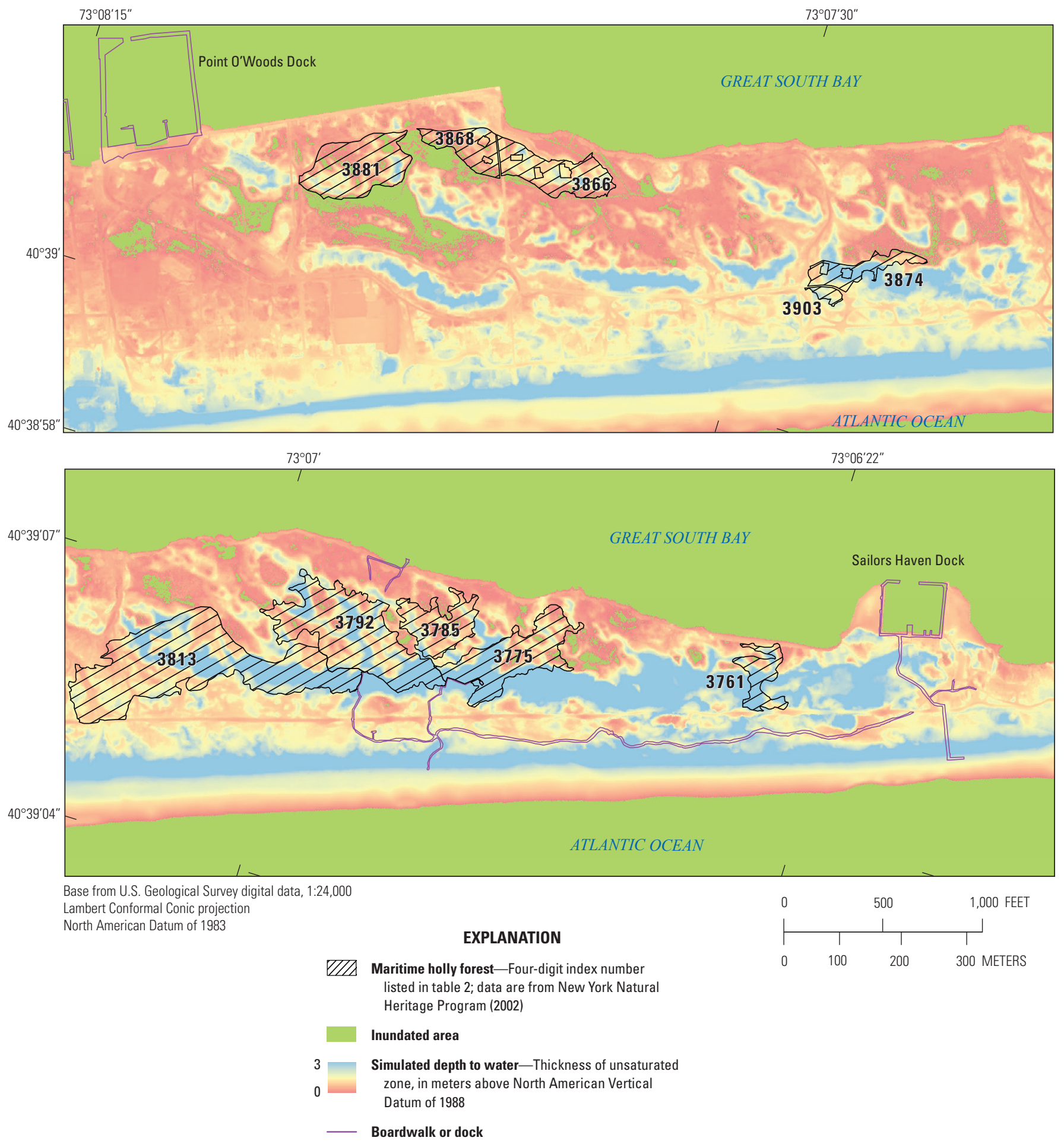

Figure 10. Maps showing depth to water in 2015 at Sunken Forest holly parcels, simulated by the Seawater Intrusion (SWI2) package of the MODFLOW-NWT three-dimensional finite-difference groundwater model, at Sailors Haven on Fire Island, New York. 


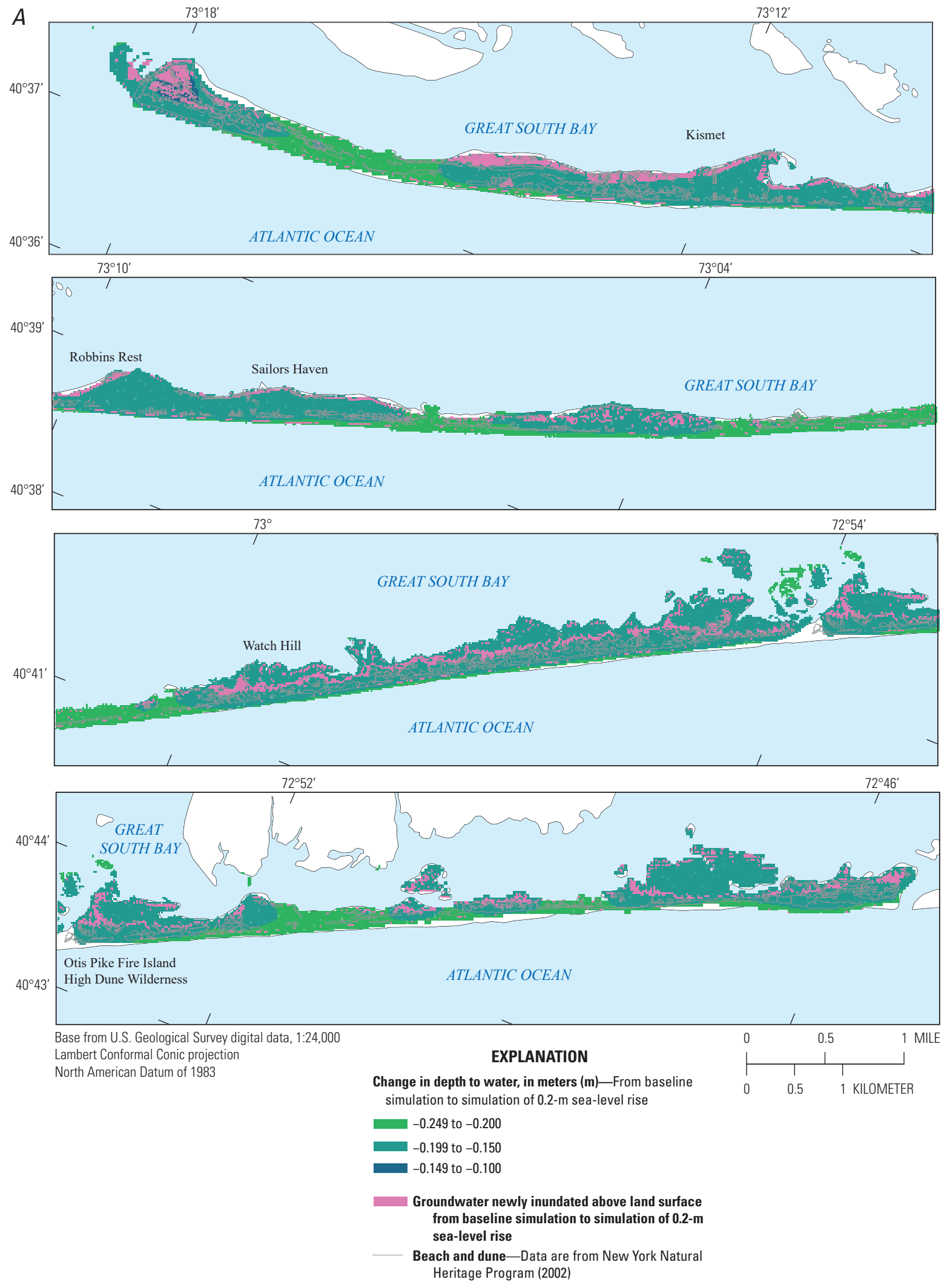

Figure 11. Maps showing simulated change in $A$, depth to water, $B$, evapotranspiration, and $C$, depth to the freshwater/saltwater interface with 0.2-meter sea-level rise on Fire Island, New York. Maps from top to bottom represent Fire Island from west to east, respectively. 


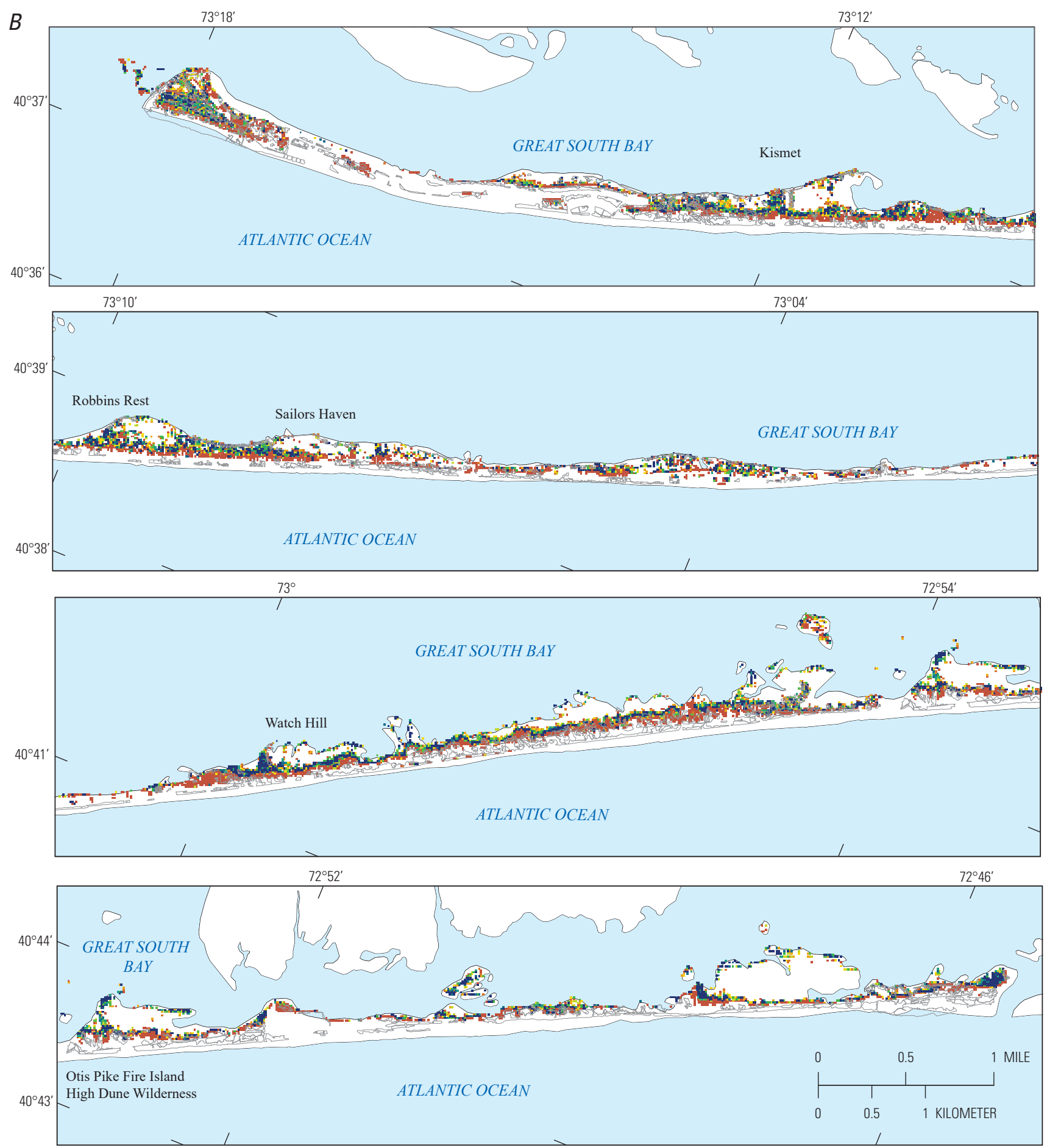

Base from U.S. Geological Survey digital data, 1:24,000 Lambert Conformal Conic projection

North American Datum of 1983

\section{EXPLANATION}

Change in evapotransipration rate from baseline simulation to simulation of 0.2-meter sea-level rise, in cubic meters per day

0.0000 to 0.0625

0.0626 to 0.1250

0.1251 to 0.1875

0.2501 to 0.3125

0.3751 to 0.4375

0.5001 to 0.5625

0.4376 to 0.5000
Beach and dune-Data are from New York Natural Heritage Program (2002)

Figure 11. - Continued 


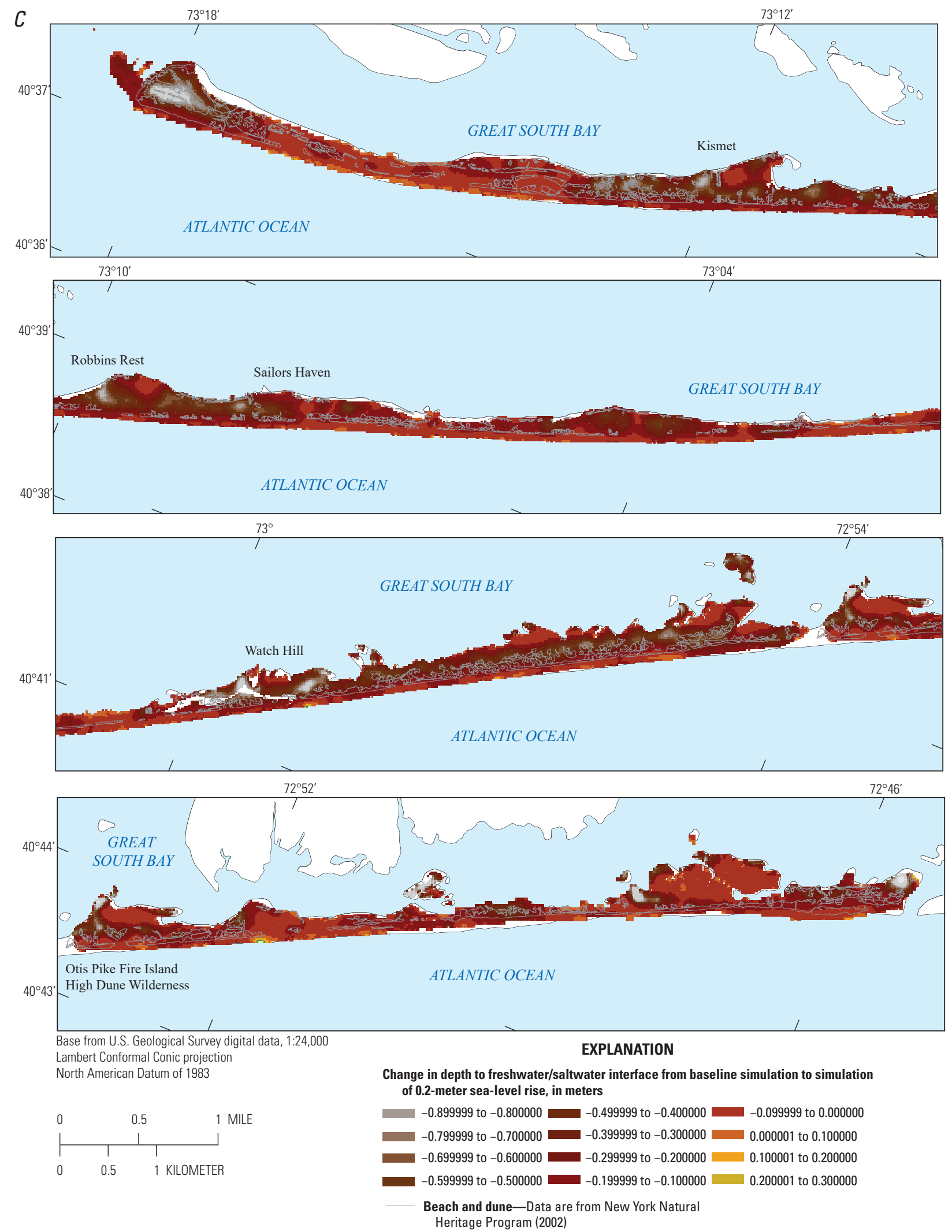

Figure 11. - Continued 

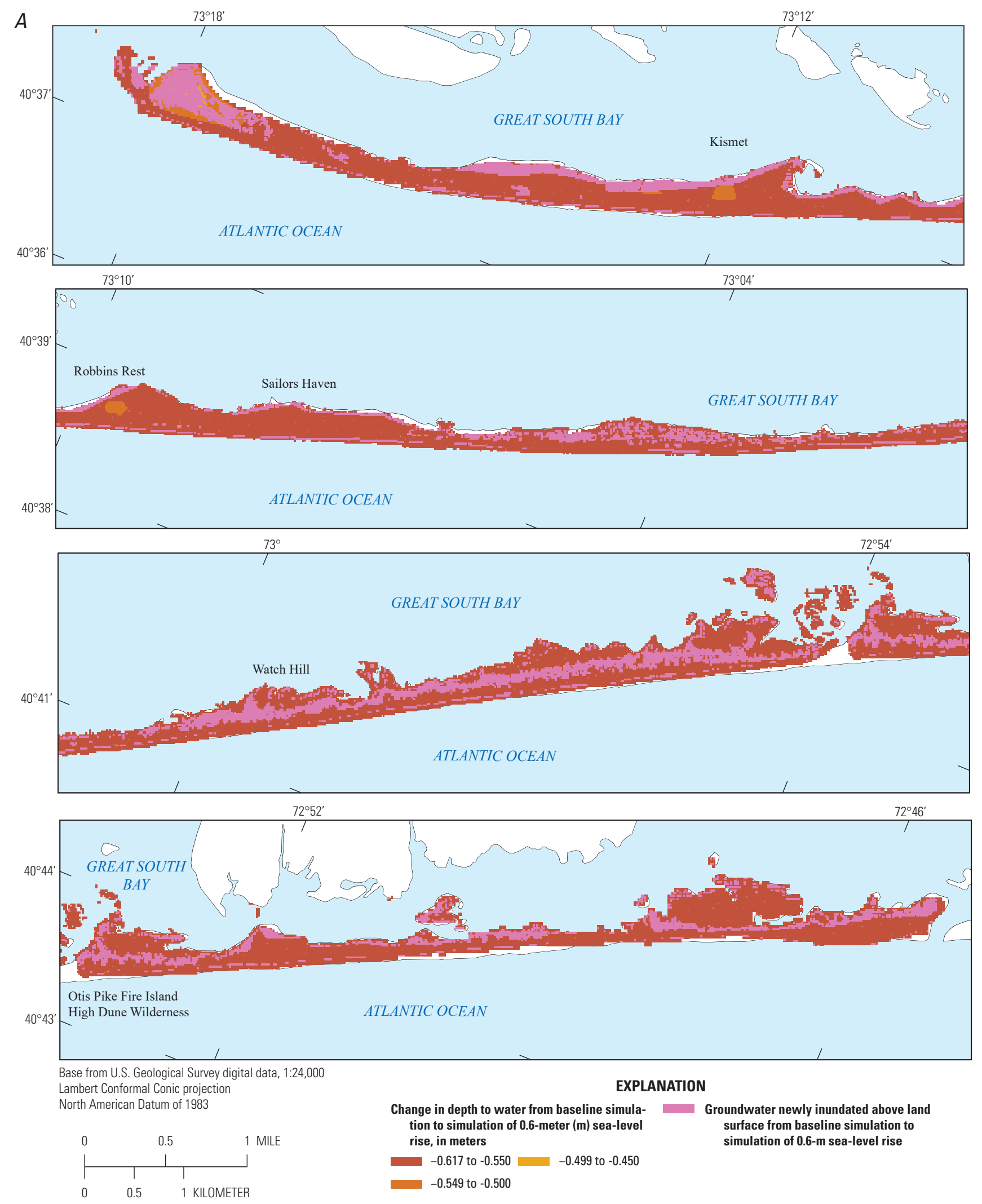

Figure 12. Maps showing simulated change in $A$, depth to water, $B$, evapotranspiration, and $C$, depth to the freshwater/saltwater interface with 0.6-meter sea-level rise on Fire Island, New York. Maps from top to bottom represent Fire Island from west to east, respectively. 


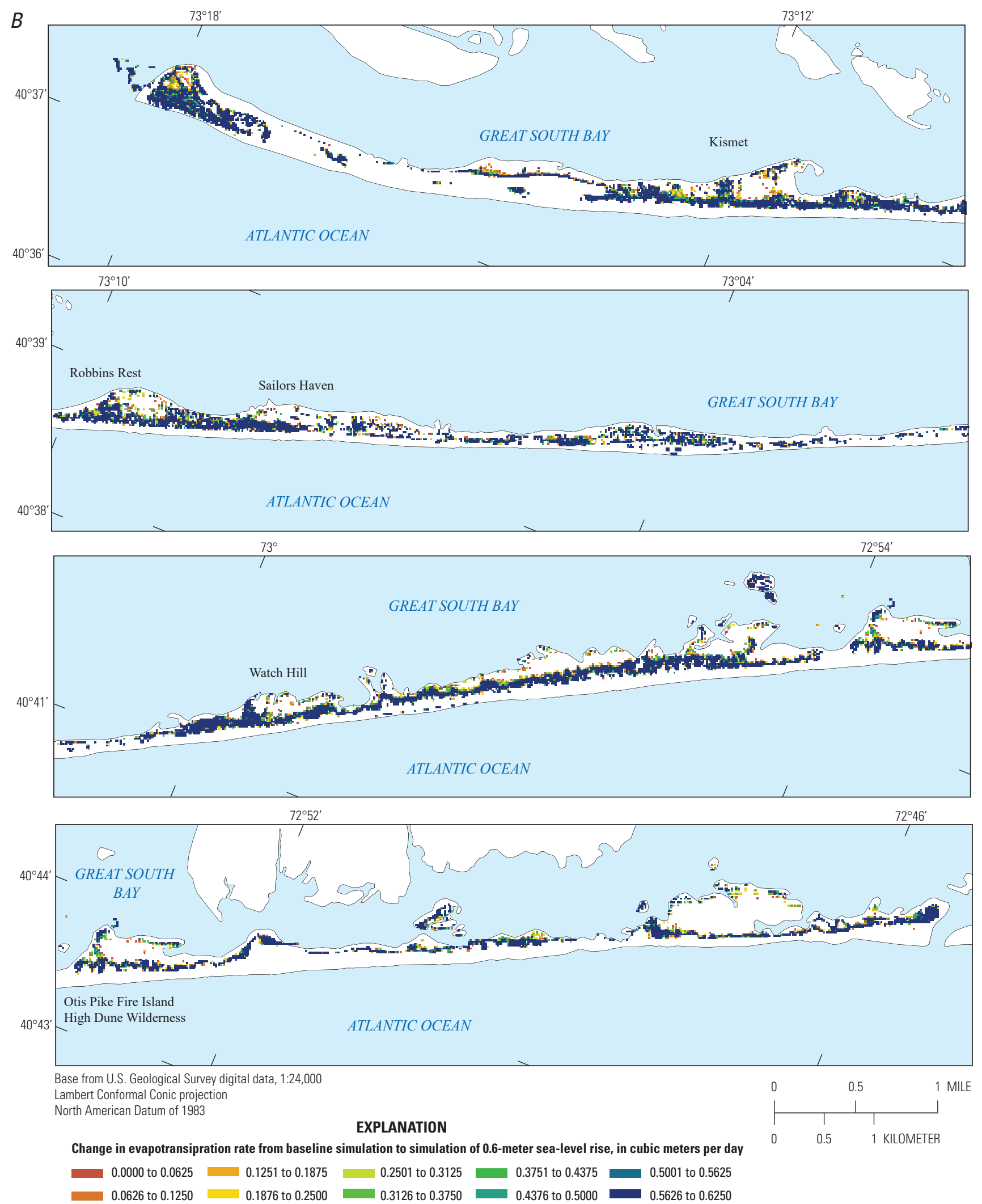

Figure 12. - Continued 

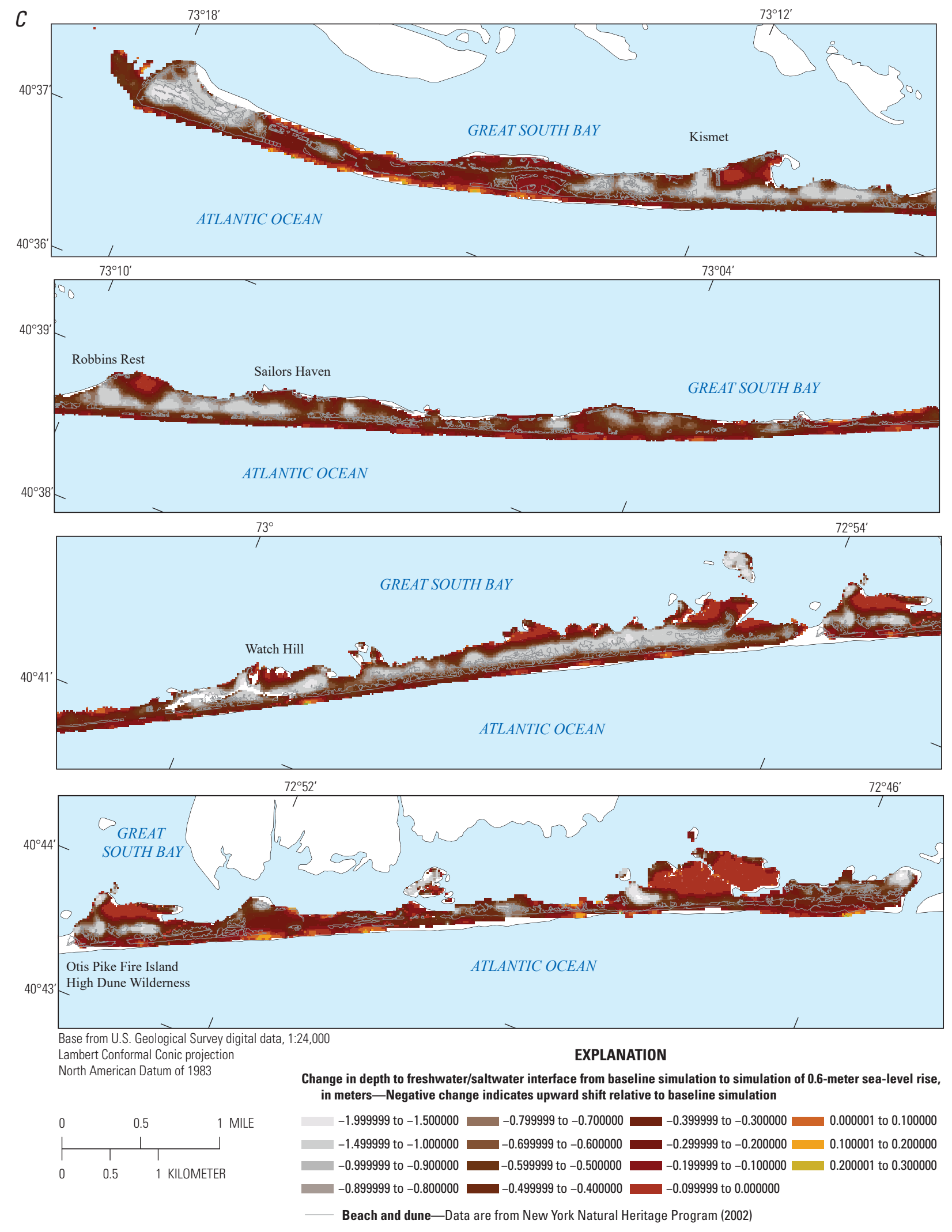

Figure 12. -Continued 

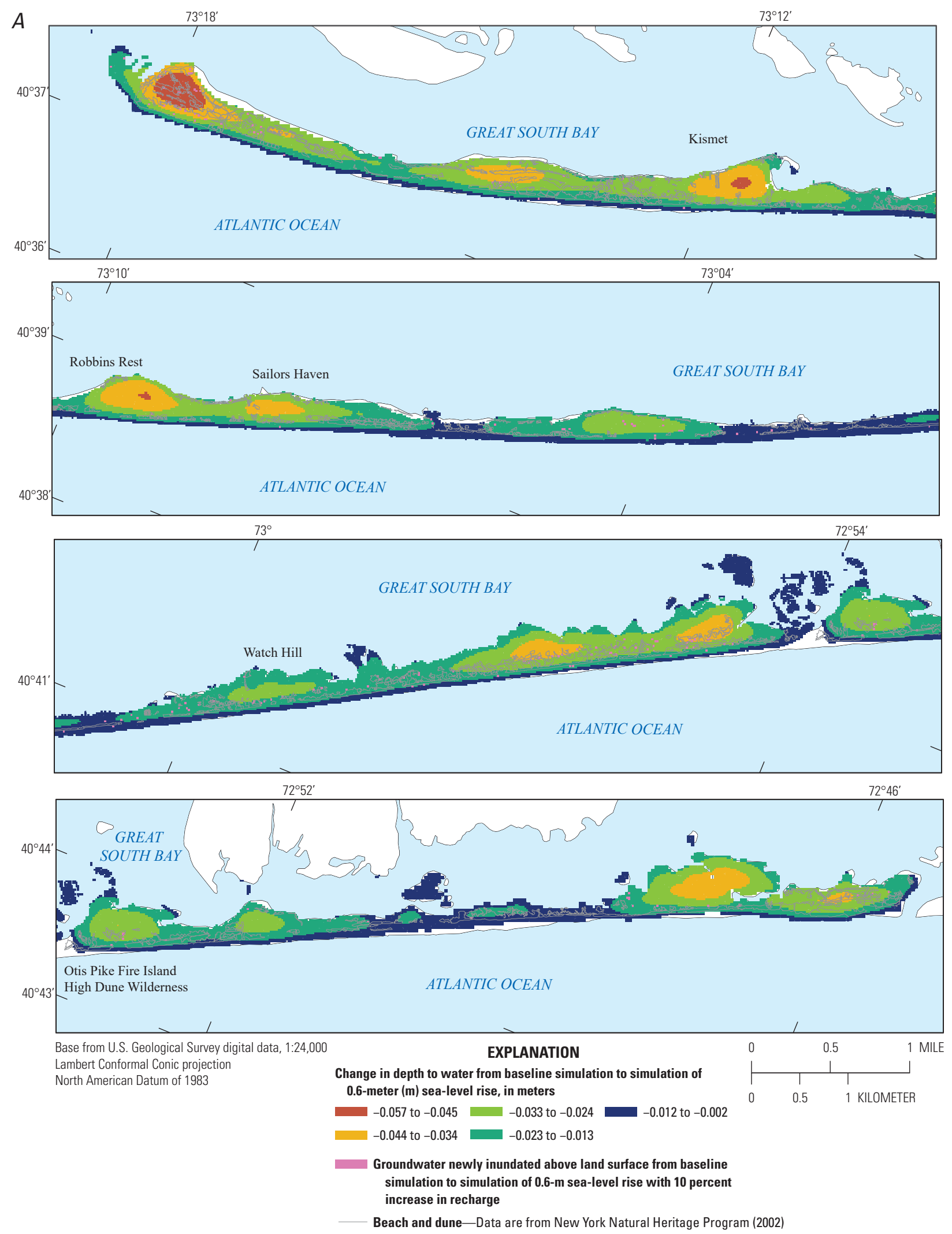

Figure 13. Maps showing simulated change in $A$, depth to water, $B$, evapotranspiration, and $C$, depth to the freshwater/ saltwater interface with 0.6-meter sea-level rise and 10-percent increase in recharge on Fire Island, New York. Maps from top to bottom represent Fire Island from west to east, respectively. 


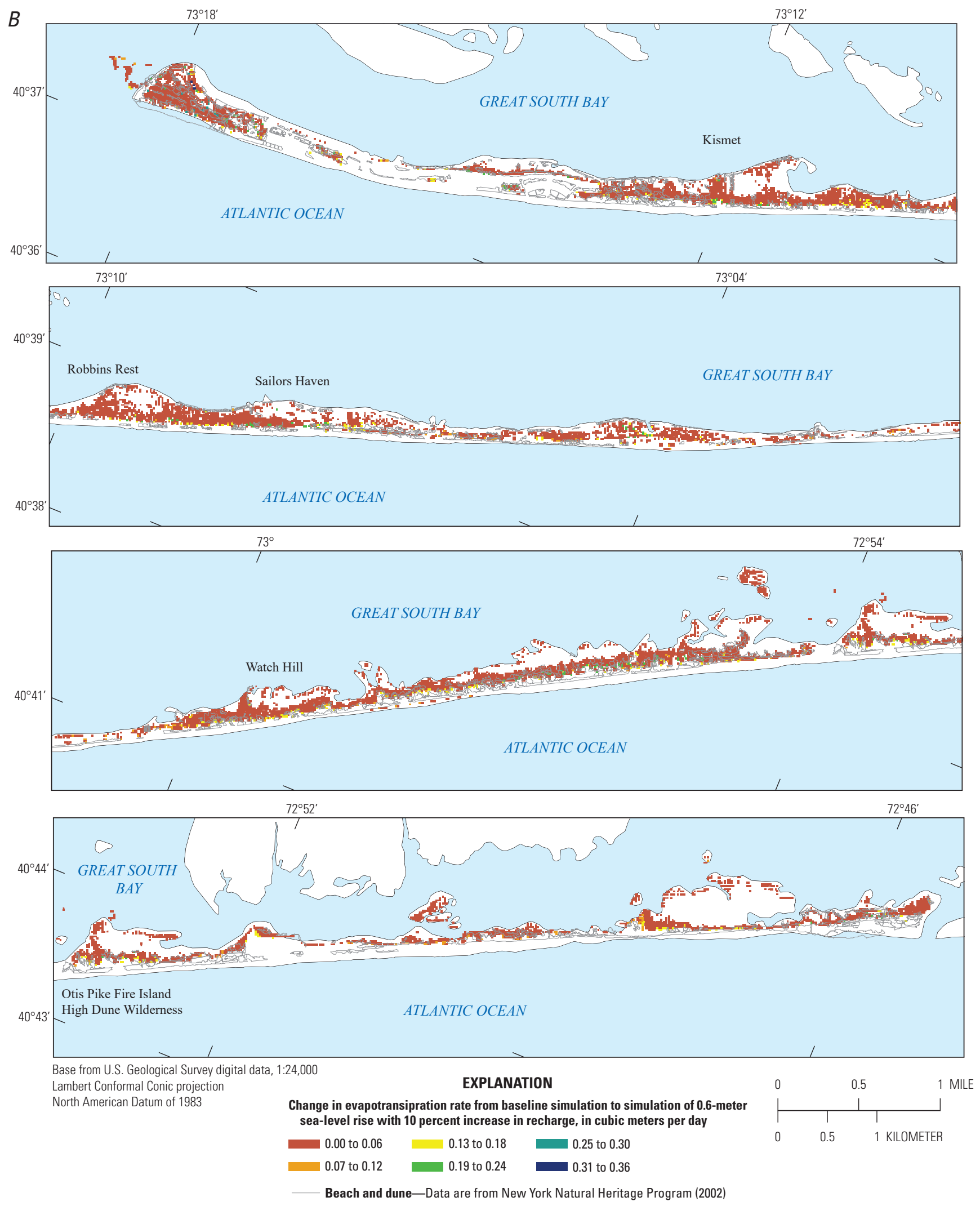

Figure 13. - Continued 

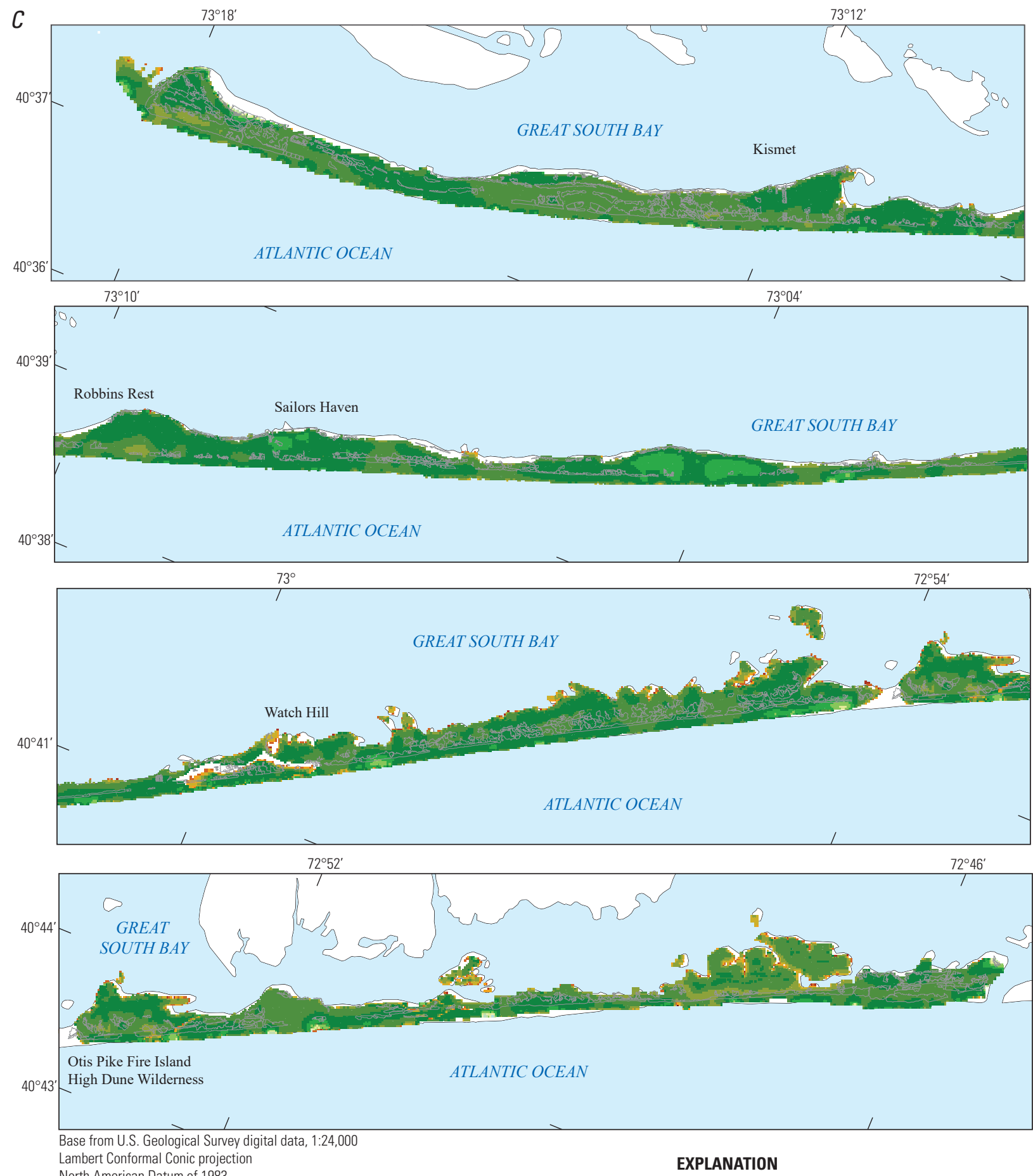

Lambert Conformal Conic projection

\section{EXPLANATION}

Change in depth to freshwater/saltwater interface from simulation of 0.6 -meter $(\mathrm{m})$ sea-leve rise to simulation of $0.6-\mathrm{m}$ sea-level rise with 10 percent increase in recharge, in meters

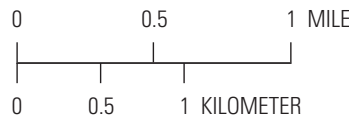

-0.299999 to $-0.200000=0.100001$ to $0.200000=0.500001$ to 0.600000

-0.199999 to $-0.100000-0.200001$ to 0.300000

$\begin{array}{ll}-0.099999 \text { to } 0.000000 & 0.300001 \text { to } 0.400000 \\ \end{array}$

0.000001 to $0.100000 \square 0.400001$ to 0.500000

— Beach and dune—Data are from New York Natural Heritage Program (2002)

Figure 13. - Continued 


\section{Change in Depth to Water Table}

The simulated changes in the depth to the water table from the baseline simulation to the $0.2-\mathrm{m}$ and $0.6-\mathrm{m}$ sea-level rise scenarios are shown in figures $12 A$ and $13 A$. Sea-level rise causes the simulated water table over most of Fire Island to rise almost as much as the change in mean sea level, and therefore for much of the land area, the change in the depth to water is about the same magnitude as but somewhat less than the sea-level rise. The depth to water also decreases by about $0.05 \mathrm{~m}$ as a result of increasing recharge by 10 percent.

\section{Recharge and Discharge Areas}

The sea-level rise and increased recharge scenarios caused the water table to rise and, therefore, increase groundwater discharge to evapotranspiration and seeps (drains). Simulated groundwater evapotranspiration only occurs when the water table is close enough to land surface for direct uptake by roots or evaporation and decreases linearly from a depth to water of $0 \mathrm{~m}$ down to an extinction (minimum) depth of $0.1 \mathrm{~m}$. Compared with the baseline scenario, simulated evapotranspiration increased from 9 percent of freshwater recharge (recharge from precipitation plus infiltrated effluent) in the baseline scenario to $10,11,12$, and 11 percent in the $0.2-, 0.4-$, and 0.6-m sea-level rise and increased recharge scenarios, respectively (figs. $11 B, 12 B$, and $13 B$; table 3 ). In some locations, there is an increase in evapotranspiration from the baseline to the $0.2-\mathrm{m}$ sea-level rise scenario but not from the 0.2-m sea-level rise scenario to other sea-level rise scenarios because the evapotranspiration may have already reached the maximum rate in the $0.2-\mathrm{m}$ sea-level rise scenario. The discharge to seeps increased from 1 percent to a maximum of 2 percent in the $0.6-\mathrm{m}$ sea-level rise scenario.

\section{Freshwater/Saltwater Interface}

Changes in the depth to the freshwater/saltwater interface are related to the changes in the water-table altitude and depth to water: where the water table does not rise as much as sealevel rise, the comparatively lower freshwater altitude above the prevailing mean sea level results in a shallower freshwater/ saltwater interface (Masterson and others, 2013b). For the four sea-level rise scenarios, the change in depth to the freshwater/ saltwater interface maps (figs. $11 C, 12 C$, and 13C) have similar patterns as the change in depth to water maps (figs. $11 \mathrm{~A}$, $12 A$, and $13 A$ ).

\section{Discussion}

Model simulations of 0.2-, 0.4-, and 0.6-m sea-level rise indicated that the water table may rise by an amount slightly less than the sea-level rise amount. The difference in rise in water-table and sea-level rise is probably owing to the water table approaching land surface, thereby increasing groundwater discharge to evapotranspiration and seeps and reducing submarine groundwater discharge. The increased discharge to land surface and reduction of longer flow paths for submarine discharge result in heads closer to the prevailing sea level and, therefore, reduced depths to the freshwater/saltwater interface. Where sea-level rise causes the simulated water table to reach land surface and increase discharge to evapotranspiration or drain boundaries, the change in depth to the water table is subdued.

As sea-level rise causes the water table to rise above a critical level for certain plants or ecosystems, these environments would likely be affected. An example of this is the Sunken Forest (Raphael, 2014). The old-growth hollies of the Sunken Forest are considered the peak expression

Table 3. Simulated flow rates to model boundaries for Fire Island, New York.

[Flow rates are for simulations for the baseline, 0.2-, 0.4-, and 0.6-meter (m) sea-level rise (SLR), and 10-percent increased recharge scenarios. Net discharge to general-head boundary is the sum of flow into and out of the groundwater model via the general-head boundary. Negative flow indicates flow out of groundwater system. $\mathrm{m}^{3} / \mathrm{d}$, cubic meter per day]

\begin{tabular}{|c|c|c|c|c|c|}
\hline & \multicolumn{5}{|c|}{ Scenario name } \\
\hline & Baseline & 0.2-m SLR & 0.4-m SLR & 0.6-m SLR & $\begin{array}{l}0.6-\mathrm{m} \text { SLR and } \\
\text { recharge increased } \\
\text { by } 10 \text { percent }\end{array}$ \\
\hline \multicolumn{6}{|c|}{ Flow into model from boundary, in $\mathrm{m}^{3} / \mathrm{d}$} \\
\hline Recharge & $56,183,900$ & $56,183,900$ & $56,183,900$ & $56,183,900$ & $61,802,188$ \\
\hline Drain & $-23,459$ & $-32,588$ & $-42,518$ & $-52,544$ & $-53,995$ \\
\hline Net discharge to general-head boundary & $-48,044,120$ & $-45,906,184$ & $-44,539,072$ & $-43,549,496$ & $-49,049,344$ \\
\hline \multicolumn{6}{|c|}{ Percentage of net recharge } \\
\hline Drain & 0 & 0.1 & 0.1 & 0.1 & 0.1 \\
\hline Evapotranspiration & 14.4 & 18.2 & 20.7 & 22.4 & 20.5 \\
\hline
\end{tabular}


of thousands of years of ecological transformation on Fire Island (Remillard and Druschke, 2015). However, not only are the hollies dying, the forest floors have become barren and standing water has emerged. Freshwater wetland herbaceous species (for example, swamp smartweed) are colonizing depression sites in the Sunken Forest perhaps because of their tolerance to a thinner unsaturated zone caused by sea-level rise, which allows them to outcompete the existing vegetation (Jordan Raphael, National Park Service, written commun., 2016). Areas where holly saplings are no longer expected to grow again have been identified as part of a coastal resilience research program (Remillard and Druschke, 2015). In addition to altering ecosystems, inundated areas may also potentially affect park infrastructure, such as roads.

A rising freshwater/saltwater interface may affect plant species. Deep holly tree roots are at risk of being affected by salinization owing to sea-level rise (Remillard and Druschke, 2015). Model simulations indicated that the rise in the freshwater/saltwater interface may be enhanced in areas where groundwater is discharged in the form of evapotranspiration or seepage. This generally coincides with areas where the water table inundates the land, such as in the holly forest where standing water has emerged. Shoreline erosion is likely also a factor by moving the shoreline closer to depressions in the Sunken Forest and, therefore, bringing the freshwater/saltwater interface closer to the surface (Raphael, 2014).

\section{Limitations of Analysis}

Groundwater flow models are simplifications of natural flow systems and cannot capture the true complexity of these systems (Anderson and Woessner, 1992). The distributions of parameter values assigned in the model were kept simple to avoid creating an overly complex model that could not be justified on the basis of existing information. The simulations completed for this study are for the steady state and do not attempt to quantify the freshwater flow system response to gradual sea-level rise or any delay in the response in the deep part of the flow system. Because the steady-state simulations use average annual rates of recharge and evapotranspiration, the simulations do not capture any seasonal changes to recharge or evapotranspiration from changing climate. Steadystate simulations were considered to be sufficient for this study because of the expected slow rate of changes in the hydrologic system driven by climate change.

The representation of the freshwater/saltwater interface as a sharp interface rather than a gradual transition zone precludes explicit simulation of changes to slightly brackish salinity isosurfaces that may be of more importance to the ecosystem than the 29-part-per-thousand salinity isosurface of ocean water. The limited scope of data collection for this study precluded the calibration of a transient simulation of the transition zone; however, transient simulations would have limited value given the long-term nature of climate change and many uncertainties in data, processes, and climate-change assumptions. The only data available to characterize the transition zone were those from previously completed observation wells (Schubert, 2010). Additional data could allow more complete characterization of the transition zone, including better estimates of the distribution of salinity in the groundwater system.

Water-level data were collected synoptically and provided widespread coverage but were limited to a few sampling dates. Additional continuous water-level data collected in different recharge and evapotranspiration zones may better constrain the estimates of recharge and evapotranspiration. The lack of streams prevents the collection of stream base flow data to constrain recharge estimates; bed seepage measurements could possibly be used to provide estimates of submarine discharge rates. Lacking in discharge data, water-level data are not sufficient to resolve the correlation between hydraulic conductivity and recharge. Aquifer-test data could provide estimates of hydraulic conductivity to reduce the uncertainty.

The horizontal and vertical discretizations were sufficient to resolve groundwater flow at a resolution consistent with the available data. Additional borehole data could provide better resolution of the horizontal and vertical extents of hydrogeologic layers. Restrictions to flow in the vertical direction can substantially affect the movement of saltwater and possibly lengthen the time required for the shallow flow system to respond to sea-level rise. Additional water-level and hydrogeologic data could allow better resolution and calibration in areas of particular concern, such as the maritime holly forest.

The magnitude of the combined effect of wave runup and tidal pumping was well constrained with the available data and the value determined by parameter estimation but was affected by uncertainties in other parameters. Additional closely spaced continuous water-level data could improve the confidence in the water-table overheight boundary and, therefore, improve estimates of depth to water because the simulated water levels are sensitive to this parameter.

This study assumed that as sea-level rises and the regime of deposition and erosion changes, the resulting morphological changes of nearshore submarine and bordering shoreline and dune areas should not substantially affect the results of the scenarios. Although morphological changes to Fire Island could be substantial, estimating or predicting those changes was beyond the scope of this study. Barrier islands may migrate inland, build dunes, change shape, or be split by new inlets as tides, winds, waves, and currents sculpt their sands. Marshes trap sediment and break down decaying plants into new soil, which may elevate them sufficiently in some areas to keep pace with sea-level rise. Although such morphological changes could substantially affect various ecosystems, assumption of static morphology allows simulation of changes in the freshwater flow system that can be used to evaluate existing ecosystems.

The model created for this study simulated only the shallow groundwater-flow system on Fire Island, specifying no-flow boundaries on the sides and bottom of the model. 
The connection between the shallow aquifer and the underlying Cretaceous sediments is thought to be minimal but this hypothesis could be tested by constructing a regional groundwater-flow model that represents the entire groundwater system of Long and Fire Islands.

\section{Use of Long-Term Monitoring to Assess Water Resources}

In conjunction with the modeling results of this study, long-term monitoring may be used to assess the water resources of Fire Island and help identify local effects of climate change on the groundwater system. Two types of monitoring are water-level and water-quality monitoring. As sea level rises and groundwater recharge changes, water-level and water-quality conditions may be observed and compared with model predictions. For example, if water levels are collected in an area of simulated water-table inundation during a sea-level rise scenario and future water levels collected within that area increase and match the simulation, then these conditions may lend confidence in the predictive capability of the simulation model. Conversely, disparity between the predictions and the observations may indicate a need for refinement of the simulation model. In addition to the monitoring wells completed by Schubert (2010) and revisited during the course of this study, other wells such as those described by Raphael (2014) may be useful for both water-level and water-quality purposes. As water is monitored, long-term changes may begin to be documented. Increases in water levels may be expected to follow sea-level rise, which is about $2.8 \mathrm{~mm} / \mathrm{yr}$ (New York State Department of Environmental Conservation, 2016). Change in water quality may include increased salinity from movement of the freshwater/saltwater interface, storm overwash, and shoreline erosion. Water-level and salinity data collection and analysis proposed in this study can be used to evaluate causes of mortality in different areas of the Sunken Forest and identify potentially threatened areas.

\section{Groundwater Levels}

The modeling results of this study can provide insight into preferred water-level monitoring locations for early warning with respect to water-table rise. Generally, measurements on an annual basis are sufficient; but at one or more easily accessible locations, a continuous record may also be indicated. An issue of concern is the possibility that a sustained rise in the water table will have a negative impact on the maritime holly forest. By identifying locations within holly forest parcels that are expected to become inundated during simulated sea-level rise scenarios, a long-term monitoring plan may be developed (fig. 14). Generally, one location per parcel is identified unless there are separate low-lying areas within a parcel (locations 1 and 2 or locations 7, 8, and 9).
The four scenarios for sea-level rise and a 10-percent increase in recharge indicated that a rise in the water table of about $0.2 \mathrm{~m}$ is a certainty. Water-level monitoring can be conveniently facilitated through use of water-level recording devices installed in observation wells. Water-level recording devices are especially useful in that they provide a continuous record, but they do require regular (every 8 to 10 weeks) maintenance and calibration. Alternatively, water-level measurements can be made manually at a lower cost, and on a monthly or semiannual basis. For a semiannual manual measurement schedule, it may be useful to make a measurement during the seasonal high-water level in March or April and during the seasonal low water level in September or October.

Sea-level rise and the water-table response are slow processes, and occasional (for example, monthly or quarterly) water-level measurements are likely sufficient to evaluate long-term threats. However, a sufficient number of measurements or limited continuous monitoring would be needed to separate short-term tidal, recharge (precipitation), or seasonal effects from long-term changes associated with sea-level rise. Water levels can be measured with pressure transducer and data-logger probes installed in observation wells.

\section{Water-Quality Samples}

Many areas on Fire Island are likely to experience increased salinity in shallow groundwater associated with sea-level rise because of thinning of the freshwater lens and increasingly frequent storm-driven inundation events (for example, low-lying maritime holly forest areas; fig. 14). The sea-level rise scenario simulations indicated that increased freshwater discharge to evapotranspiration and groundwater seeps is likely to cause the freshwater/saltwater interface to upcone underneath these boundaries. This thinning of the freshwater lens could be further exacerbated by an increasing frequency of storm-driven inundation caused by sea-level rise. Possible effects of global climate change include the potential for increasing frequency and intensity of coastal storms causing more frequent or severe inundation of lowlying areas. In general, monitoring of specific conductance is a reasonable surrogate for salinity and chloride concentration and can be done with specific-conductance and data-logger probes installed in observation wells. Alternatively, analysis of chloride concentration from well water is inexpensive, but the quality control of well sampling requires purging (pumping) of about three well volumes before sampling to ensure the sample is representative of the aquifer water in the vicinity of the well. In addition, periodic electromagnetic induction logging of wells may be useful to monitor changes in water quality. 


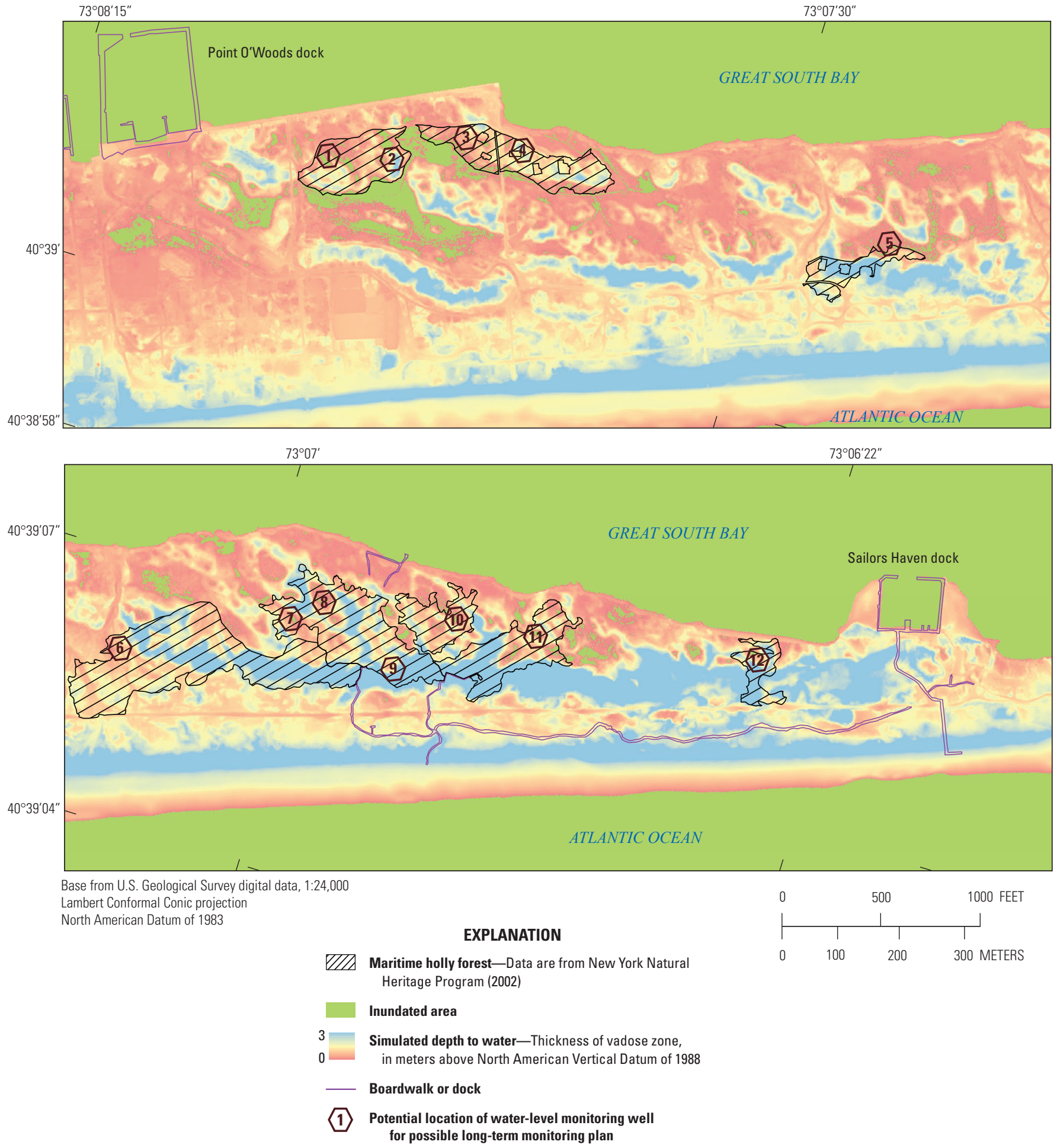

Figure 14. Maps showing potential long-term monitoring locations at Sailors Haven on Fire Island, New York. Location of Sailors Haven shown in figure 2. 


\section{Summary}

Among the most vulnerable natural resources of Fire Island National Seashore on Fire Island, New York, are the island's fresh groundwater resources because groundwater is physically close to saline water bodies. Indigenous species such as the federally listed threatened or endangered piping plover, roseate tern shorebirds, and seabeach amaranth that live on Fire Island may be affected by changes in the groundwater system. Accelerated sea-level rise is expected to change the quantity and quality of groundwater resources and thereby threaten habitats sensitive to hydrologic change, such as the maritime holly forest at Sailors Haven. In order to inform management decisions about adaptation to sea-level rise, the U.S. Geological Survey, in cooperation with the National Park Service, assessed the associated responses of groundwater resources. The analysis included identification of baseline conditions of groundwater resources by continuously monitoring a network of wells and by geophysical logging, development of groundwater-flow models to simulate climate-change mechanisms including sea-level rise along the ocean and bay shores, and analysis of a limited number of projected future scenarios.

From the sea-level rise scenarios that were simulated, land areas that may experience holly root-zone stress owing to upward movement of the water table were delineated. A three-dimensional groundwater-flow model was developed to simulate changes in depth to the water table and depth to saltwater interfaces owing to climate-related changes on Fire Island. An existing SEAWAT three-dimensional variabledensity groundwater flow and transport model was converted to a MODFLOW-NWT three-dimensional finite-difference groundwater model with the Seawater Intrusion (SWI2) package and recalibrated using the UCODE_2005 automatic calibration software. The simulated groundwater divide was found to skew strongly toward the ocean shore in response to the modeled wave (surf) overheight.

The principal findings of this study relate to potential effects of climate change on simulated depth to the water table and freshwater/saltwater interface. These depths decrease as climate change progresses, both with respect to sea-level rise and recharge change. Sea-level rise scenarios included specified uniform, steady-state 0.2-, 0.4-, and 0.6-meter increases above the 2015 sea level, applied to the existing topography. A high-recharge scenario specified increased recharge rates by 10 percent from that in 2015 , and a low-recharge scenario specified decreased recharge by 10 percent from that in 2015 . More monitoring of the vulnerable areas within this study should enable verification and auditing of the modeling results and evaluation of the performance of the simulations by comparing how the expected changes actually happen in the future.

\section{References Cited}

Anderson, M.P., and Woessner, W.W., 1992, Applied groundwater modeling-Simulation of flow and advective transport: San Diego, Academic Press, Inc., 381 p.

Ataie-Ashtiani, B., Volker, R.E., and Lockington, D.A., 1999, Tidal effects on sea water intrusion in unconfined aquifers: Journal of Hydrology (Amsterdam), v. 216, no. 1-2, p. $17-31$.

Bakker, M., Schaars, F., Hughes, J.D., Langevin, C.D., and Dausman, A.M., 2013, Documentation of the seawater intrusion (SWI2) package for MODFLOW: U.S. Geological Survey Techniques and Methods, book 6, chap. A46, 47 p. [Also available at https://doi.org/10.3133/tm6A46.]

Buxton, H.T., and Smolensky, D.A., 1999, Simulation of the effects of development of the ground-water flow system of Long Island, New York: U.S. Geological Survey Water Resources Investigations Report 98-4069, 57 p. [Also available at https://doi.org/10.3133/wri984069.]

Carleton, G.B., Charles, E.G., Fiore, A.R., and Winston, R.B., 2021, Simulation of water-table response to sea-level rise and change in recharge, Sandy Hook unit, Gateway National Recreation Area, New Jersey: U.S. Geological Survey Scientific Investigations Report 2020-5080, 91 p., https://doi.org/ 10.3133/ sir20205080.

Danielson, J.J., Poppenga, S.K., Brock, J.C., Evans, G.A., Tyler, D.J., Gesch, D.B., Thatcher, C.A., and Barras, J.A., 2016, Topobathymetric elevation model development using a new methodology - Coastal national elevation database: Journal of Coastal Research, v. 76, no. special issue, p. $75-89$.

Doriski, T.P., and Wilde-Katz, F., 1983, Geology of the "20-foot" clay and Gardiners clay in southern Nassau and southwestern Suffolk Counties, Long Island, New York: U.S. Geological Survey Water-Resources Investigations Report 82-4056, 17 p. [Also available at https://doi.org/ 10.3133/wri824056.].

Fleming, B.J., Raffensperger, J.P., Goodling, P.J., and Masterson, J., 2021, Simulated effects of sea-level rise on the shallow, fresh groundwater system of Assateague Island, Maryland and Virginia: U.S. Geological Survey Scientific Investigations Report 2020-5104, 62 p., https://doi.org/ 10.3133/sir20205104.

Hayden, B.P., Santos, M.C., Shao, G., and Kochel, R.C., 1995, Geomorphological controls on coastal vegetation at the Virginia Coast Reserve: Geomorphology, v. 13, no. 1-4, p. 283-300. 
Holding, S., and Allen, D.M., 2015, From days to decadesNumerical modelling of freshwater lens response to climate change stressors on small low-lying islands: Hydrology and Earth System Sciences, v. 19, no. 2, p. 933-949.

Intergovernmental Panel on Climate Change, 2008, Climate change 2007-Synthesis report; Contribution of Working Groups I, II and III to the fourth assessment report of the Intergovernmental Panel on Climate Change: Intergovernmental Panel on Climate Change, 73 p. [Also available at https://www.ipcc.ch/publications_and_data/ publications_and_data_reports.shtml.]

Jensen, H.M., and Soren, J., 1974, Hydrogeology of Suffolk County, Long Island, New York: U.S. Geological Survey Hydrologic Investigation Atlas HA-501, 2 sheets, scale 1:250,000. [Also available at https://doi.org/10.3133/ha501.]

Jones, C.R., and Schubel, J.R., 1980, Distribution of surficial sediment and eelgrass in Great South Bay, New York (from Smith Point, west to Wantagh State Parkway): Stony Brook, N.Y., State University of New York at Stony Brook, Marine Sciences Research Center Special Report 39, ref. $80-6,19$ p.

Langevin, C.D., Thorne, D.T., Jr., Dausman, A.M., Sukop, M.C., and Guo, W., 2007, SEAWAT version 4-A computer program for simulation of multi-species solute and heat transport: U.S. Geological Survey Techniques and Methods, book 6, chap. A22, 39 p. [Also available at https://doi.org/ 10.3133/tm6A22.]

Leggette, Brashears, and Graham, Inc., 1996, Ground-water resources of Fire Island, New York: Suffolk County Water Authority, [variously paged].

LoCicero, P.V.R., 2006, The history of benthic habitat and associated mollusk assemblages in Great South Bay, New York: Stony Brook, N.Y., State University of New York at Stony Brook, Master's thesis, $77 \mathrm{p}$.

Masterson, J.P., Fienen, M.N., Gesch, D.B., and Carlson, C.S., 2013a, Development of a numerical model to simulate groundwater flow in the shallow aquifer system of Assateague Island, Maryland and Virginia: U.S. Geological Survey Open-File Report 2013-1111, 34 p. [Also available at https://doi.org/10.3133/ofr20131111.]

Masterson, J.P., Fienen, M.N., Thieler, E.R., Gesch, D.B., Gutierrez, B.T., and Plant, N.G., 2013b, Effects of sea-level rise on barrier island groundwater system dynamicsEcohydrological implications: Ecohydrology, v. 7, no. 3, p. 1064-1071.

Melillo, J.M., Richmond, T.C., and Yohe, G.W., eds., 2014, Climate change impacts in the United States: U.S. Global Change Research Program, 829 p. [Also available at https://doi.org/10.7930/J0Z31WJ2.]
Miller, J.F., and Frederick, R.H., 1969, The precipitation regime of Long Island, N.Y.: U.S. Geological Survey Professional Paper 627-A, 21 p., 1 pl. [Also available at https://doi.org/10.3133/pp627A.]

Misut, P.E., 2021, MODFLOW-NWT model used to simulate water-table and freshwater/saltwater interface response to climate-change-driven sea-level rise and changes in recharge at the Fire Island National Seashore, New York: U.S. Geological Survey data release, https://doi.org/ 10.5066/P95TBIMW.

National Park Service, 2002, Spatial vegetation data: National Park Service Fire Island National Seashore Vegetation Mapping Project data, accessed March 17, 2016, at https://www.sciencebase.gov/catalog/item/ 541ca909e4b0e96537e0a41e.

National Park Service, 2010, Climate change response strategy: National Park Service, 28 p. [Also available at https://data.globalchange.gov/report/nps-ccrs-2010.]

National Park Service, 2016, Threatened and endangered species: National Park Service Fire Island National Seashore web page, accessed October 4, 2016, at https://www.nps.gov/fiis/learn/nature/threatened-andendangered-species.htm.

New York Natural Heritage Program, 2002, NPS vegetation mapping program: Vegetation of Fire Island National Seashore: Albany, N.Y., accessed April 12, 2019, at https://www1.usgs.gov/vip/fiis/fiis.zip.

New York State Department of Environmental Conservation, 2016, Sea level rise-What is expected for New York: New York State Department of Environmental Conservation web page, accessed October 4, 2016, at https://www.dec.ny.gov/energy/45202.html.

Nielsen, P., 1990, Tidal dynamics of the water table in beaches: Water Resources Research, v. 26, no. 9, p. 2127-2134.

Niswonger, R.G., Panday, S., and Ibaraki, M., 2011, MODFLOW-NWT, a Newton formulation for MODFLOW-2005: U.S. Geological Survey Techniques and Methods, book 6, chap. A37, 44 p. [Also available at https://doi.org/10.3133/tm6A37.]

Raphael, J., 2014, 50 years of vegetation change in a holly maritime forest: Hempstead, N.Y., Hofstra University master's thesis, ProQuest UMI no. 1573792, 92 p.

Remillard, J., and Druschke, C.G., 2015, This park's personality_Jordan Raphael and the quest to preserve the Sunken Forest: National Park Service Hurricane Sandy employee profile, 3 p. [Also available at https://www.nps.gov/articles/ ncbn-quest-to-preserve-the-sunken-forest.htm.] 
Ross, M.S., O’Brien, J.J., and Sternberg, L. da S.L., 1994, Sea-level rise and the reduction in pine forests in the Florida Keys: Ecological Applications, v. 4, no. 1, p. 144-156.

Saha, A.K., Saha, S., Sadle, J., Jiang, J., Ross, M.S., Price, R.M., Sternberg, L. da S.L., and Wendelberger, K.S., 2011, Sea level rise and south Florida coastal forests: Climatic Change, v. 107, no. 1, p. 81-108.

Schubert, C.E., 2010, Analysis of the shallow groundwater flow system at Fire Island National Seashore, Suffolk County, New York: U.S. Geological Survey Scientific Investigations Report 2009-5259, 107 p. [Also available at https://doi.org/10.3133/sir20095259.]

Smolensky, D.A., Buxton, H.T., and Shernoff, P.K., 1989, Hydrogeologic framework of Long Island, New York: U.S. Geological Survey Hydrologic Investigations Atlas 709, scale $1: 250,000,3$ sheets.
Terry, J.P., and Chui, T.F.M., 2012, Evaluating the fate of freshwater lenses on atoll islands after eustatic sea-level rise and cyclone-driven inundation-A modelling approach: Global and Planetary Change, v. 88-89, p. 76-84.

Teskey, R.O., and Hinckley, T.M., 1977, The southern forest region, v. II of Impact of water level changes on woody riparian and wetland communities: U.S. Fish and Wildlife Service Federal Government Series FWS/OBS-77/59, 46 p.

U.S. Geological Survey, [undated], Coastal national elevation database (CoNED) applications project: U.S. Geological Survey coastal changes and impacts, accessed March 29, 2017, at https://www.usgs.gov/core-science-systems/ eros/coned.

Werner, A.D., and Simmons, C.T., 2009, Impact of sea-level rise on sea water intrusion in coastal aquifers: Ground Water, v. 47, no. 2, p. 197-204. 


\section{Appendix 1 Groundwater-Flow Model Design and Calibration}

Groundwater flow on Fire Island is simulated using a modified version of the model from Schubert (2010). This model differs by replacing the SEAWAT/MODFLOW-2000 (Langevin and others, 2007) code with MODFLOW-NWT (Niswonger and others, 2011) and the Seawater Intrusion (SWI2) package (Bakker and others, 2013). The six-layer, quasi-steady-state MODFLOW-NWT three-dimensional finite-difference groundwater model with the SWI2 package has no-flow boundaries around the sides and the bottom. Where the top of the simulated area is covered with saltwater, the top surface is a specified-head boundary with source-water density equal to ocean or bay water. Where the top of the simulated area is above mean sea level, recharge enters the model across the upper boundary. Groundwater discharges from the model as groundwater evapotranspiration, as groundwater seeps, or submarine groundwater discharge.

\section{Modifications to Existing Model}

The model of Schubert (2010) was developed with a proprietary graphical user interface; for this report, the code from the SEAWAT (Langevin and others, 2007) threedimensional variable-density groundwater flow and transport model was translated into fully open-source software, including the graphical user interface ModelMuse (Winston, 2009; U.S. Geological Survey, 2016a) and SWI2 (Bakker and others, 2013). Furthermore, SWI2 results were then translated into SEAWAT-equivalent forms for comparison (fig. 1.1). SWI2 simulated three-dimensional vertically integrated variable-density groundwater flow and seawater intrusion. The MODFLOW suite of codes (U.S. Geological Survey, 2016b) formed the basis for representing three-dimensional geometry and complex boundary conditions in SWI2; SEAWAT was based on MODFLOW-2000. Owing to a lack of consistency between the data structures of MODFLOW-2000 and MODFLOW-2005, it is not feasible to fully preprocess and postprocess SEAWAT models within the ModelMuse interface.

The baseline boundary conditions specified in the flow model for this report generally coincide with the hydrologic boundaries of the 2005 conditions described in Schubert (2010). Some minor modifications were made to represent changes from 2005 to 2015, such as using the Coastal National Elevation Database (CoNED; Danielson and others, 2016; U.S. Geological Survey, undated), which is an improved, 1-m light detection and ranging (lidar) remote-sensing dataset. Additional boundary conditions were also established for climate change scenarios.

Schubert (2010) treats in detail the construction of overheight boundary conditions from wave setup and tidal pumping. The offshore surface-water zones were characterized differently in the SEAWAT model than in the SWI2 model owing to differing model requirements. In the SEAWAT model, the top model layer has top altitude corresponding to sea level and bottom corresponding to sea floor. In the SWI2 model, layer 1 is inactive offshore, and the topmost active model layer (layer 2) has top altitude corresponding to the seafloor. The SEAWAT model requires specification of a continuous distribution of salinity throughout the offshore zone, whereas the SWI2 model assumes constant seawater density throughout the seafloor. The dimensionless seawater density in the SWI2 model is 0.022 (2.2 percent more dense than freshwater), corresponding to a salinity of 29 parts per thousand. The SEAWAT model outputs salinities and hydraulic heads that are referenced to the simulated density (a function of salinity) at a given location and time, whereas the SWI2 model outputs freshwater/saltwater interface altitudes (zeta surfaces) and freshwater equivalent hydraulic heads at all locations. The SWI2 method is a simplification of the SEAWAT method in that water density is not fully variable nor are dispersive transport mechanisms represented. However, the SWI2 package yields sufficiently accurate results for the purposes of this study. SWI2 results are more easily reproduced owing to a quicker runtime of the model, improved model-convergence characteristics, and the availability of the open-source graphical user interface and geographic information system ModelMuse (Winston, 2009).

\section{Discretization}

The 25-meter $(\mathrm{m})$ model grid encompasses the full extent of Fire Island and consists of 145 rows, 2,015 columns, and 6 layers (figs. 1.2 and 1.3). In total, the grid contains about 900,000 active model cells where groundwater-flow simulation is relevant to study objectives. In far offshore areas, groundwater is saline at hydrostatic pressure, thus lacking a driving force of flow and therefore considered inactive. The model grid is a four-to-one horizontal rediscretization of the 50-millimeter (mm) grid described in Schubert (2010), allowing for greater detail in the simulated head surfaces and simulated groundwater discharge boundaries and facilitating the assessment of groundwater change at land-parcel scale. The grid has a uniform horizontal discretization of $25 \mathrm{~m}$ along rows and columns and is oriented 20.16 degrees counterclockwise from true west along the long direction of the grid (fig. 1.2). The model represents the full thickness of the shallow aquifer system, extending from the water table to the base of the upper glacial aquifer. Layer thicknesses vary from cell to cell and generally are based on the geometry of the hydrogeologic units. Owing to less stringent requirements for vertical discretization in the SWI2 package than the SEAWAT (Langevin and others, 2007) code used in Schubert (2010), 


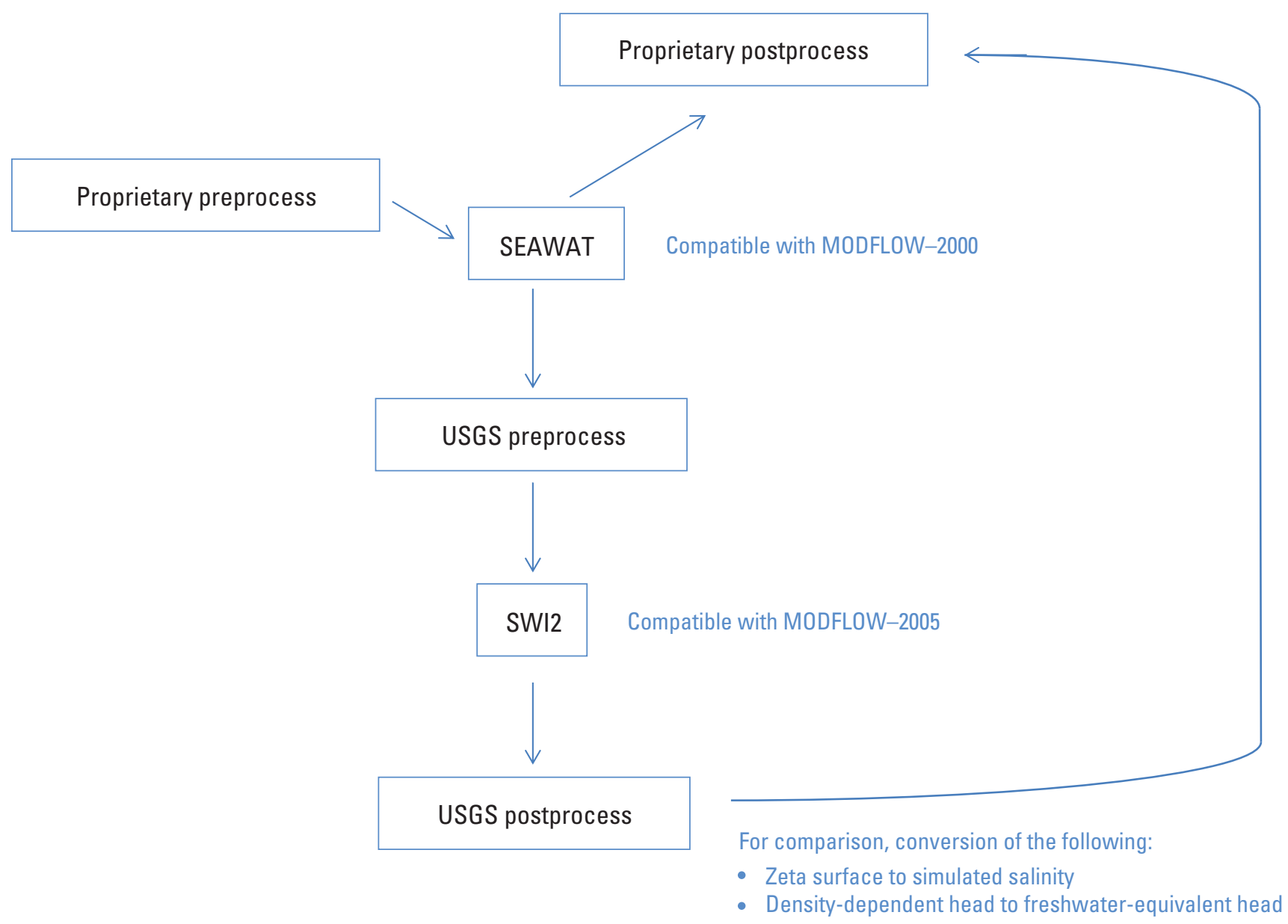

Figure 1.1. Flowchart of the SEAWAT (Langevin and others, 2007) three-dimensional variable-density groundwater flow and transport model and MODFLOW-NWT three-dimensional finite-difference groundwater model with the Seawater Intrusion (SWI2) package preprocessing and postprocessing.

SEAWAT model layers 3 to 5, 6 to 8 and 10 to 12 are each combined into single SWI2 layers, reducing the total number of model layers from 12 in Schubert (2010) to 6 within this model.

Onshore, the top layer is partially saturated and bounded on the top by the land surface. Topography and bathymetry altitudes were updated from Schubert (2010) to CoNED (U.S. Geological Survey, undated). The methodology to create CoNED is described by Danielson and others (2016). CoNED represents post-Hurricane Sandy conditions, including features such as hurricane overwash deposits (fig. 1.4).

\section{Hydraulic Properties}

All hydraulic conductivity values (table 1.1) used for the SWI2 model correspond to the calibrated SEAWAT model of Schubert (2010) and were applied without change to the SWI2 model. These aquifer properties are similarly characterized by earlier studies such as McClymonds and Franke (1972) and Smolensky and others (1989). Zonations of hydraulic conductivity, comprehensively mapped in Schubert (2010), are also applied without change. Cross-section $A-A^{\prime}$ (fig. 1.3) represents most of the hydrogeologic units present in these models. Effective porosity was also applied without change and uniformly set to 30 percent. Aquifer storage parameters are not necessary for the steady-state models of this study; however, values applied in previous modeling studies on Long Island are summarized by Buxton and Smolenksy (1999), with specific-yield values ranging from 0.1 to 0.3 and a specific storage of $6.0 \times 10^{-7}$ per foot $\left(1.8 \times 10^{-7}\right.$ per meter $)$ for all confining units. 


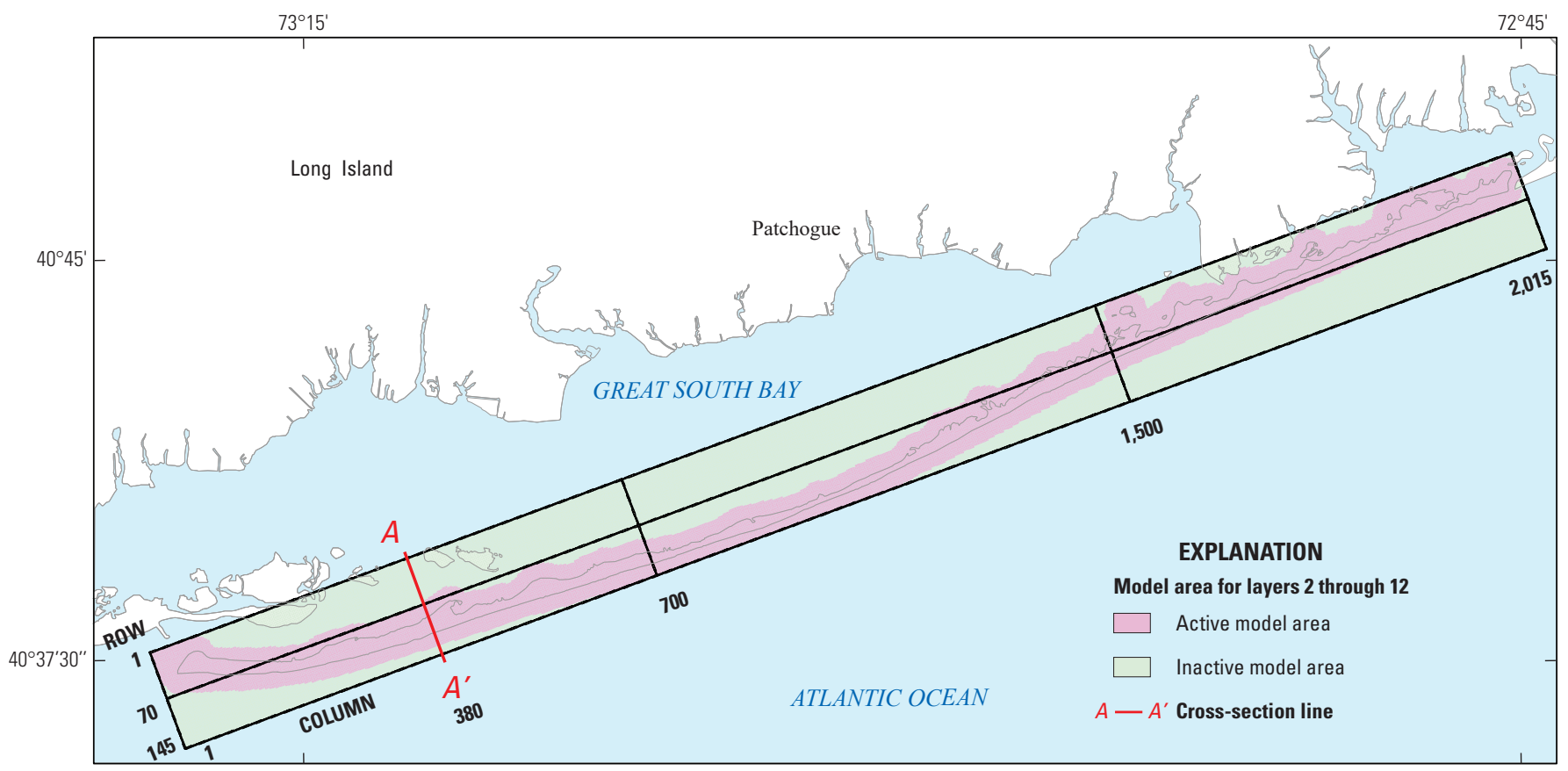

Base from U.S. Geological Survey digital data, 1:24,000 Lambert Conformal Conic projection North American Datum 1983
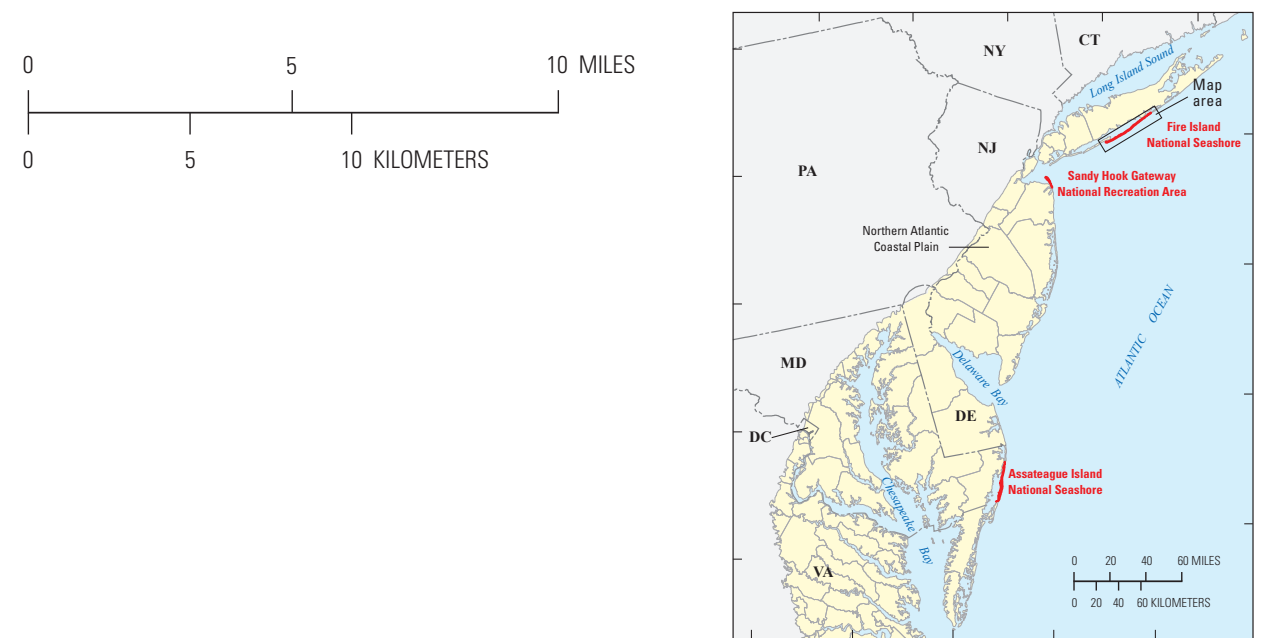

Figure 1.2. Grid for the MODFLOW-NWT three-dimensional finite-difference groundwater model with the Seawater Intrusion (SWI2) package of Fire Island, New York.

\section{Boundary Conditions}

The baseline boundary conditions (table 3, main text) are assumed to be constant through a single steady-state simulation but could vary between simulations. No-flow conditions are specified at the lateral boundary between active and inactive model zones and at the bottom of the lowest model layer, which represents the base of the upper glacial aquifer and, subsequently, the top of a regionally extensive confining unit. Recharge acts as a specified-flux boundary at the water table. Evapotranspiration is represented in wetland areas using the MODFLOW-NWT Evapotranspiration (EVT) package (Niswonger and others, 2011). During climate change scenarios, recharge and evapotranspiration may either increase or decrease. General-head boundaries are used in estuaries and the ocean to represent the flow of fresh and saline waters between the shallow aquifer and marine surface waters. General-head water levels increase during climate change scenarios. There is some aquifer discharge to drains and freshwater wetlands though evapotranspiration. Parameters of all steady-state, present-condition stresses are generally fixed at SEAWAT model values or equivalents from Schubert (2010); however, as part of the current study, both recharge and general-head boundary stresses were varied during hypothetical simulations of climate change; this process is described further in this section. 


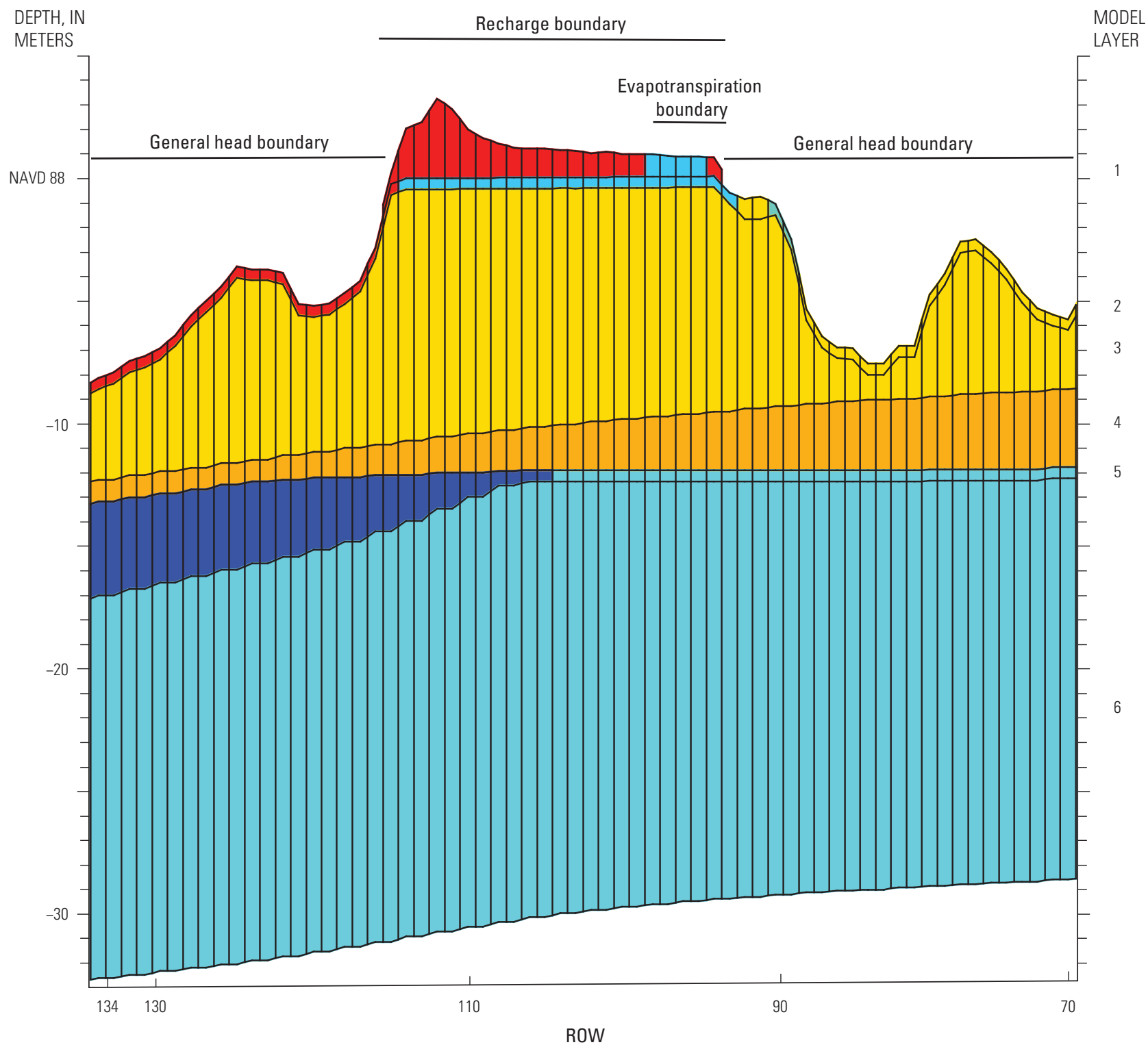

VERTICAL SCALE GREATLY EXAGGERATED

\section{EXPLANATION}

\section{Hydrogeologic unit}

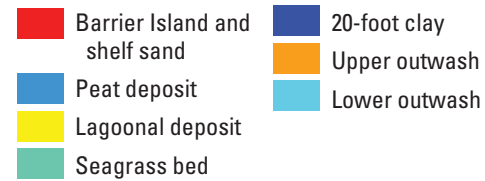

Figure 1.3. Rows and columns for the MODFLOW-NWT three-dimensional finite-difference groundwater model with the Seawater Intrusion (SWI2) package along cross-section $A-A^{\prime}$, showing hydrogeologic units and boundary conditions on Fire Island, New York. Location of cross section is shown in figure 1.2. Altitude is measured relative to the North American Vertical Datum of 1988 (NAVD 88). 


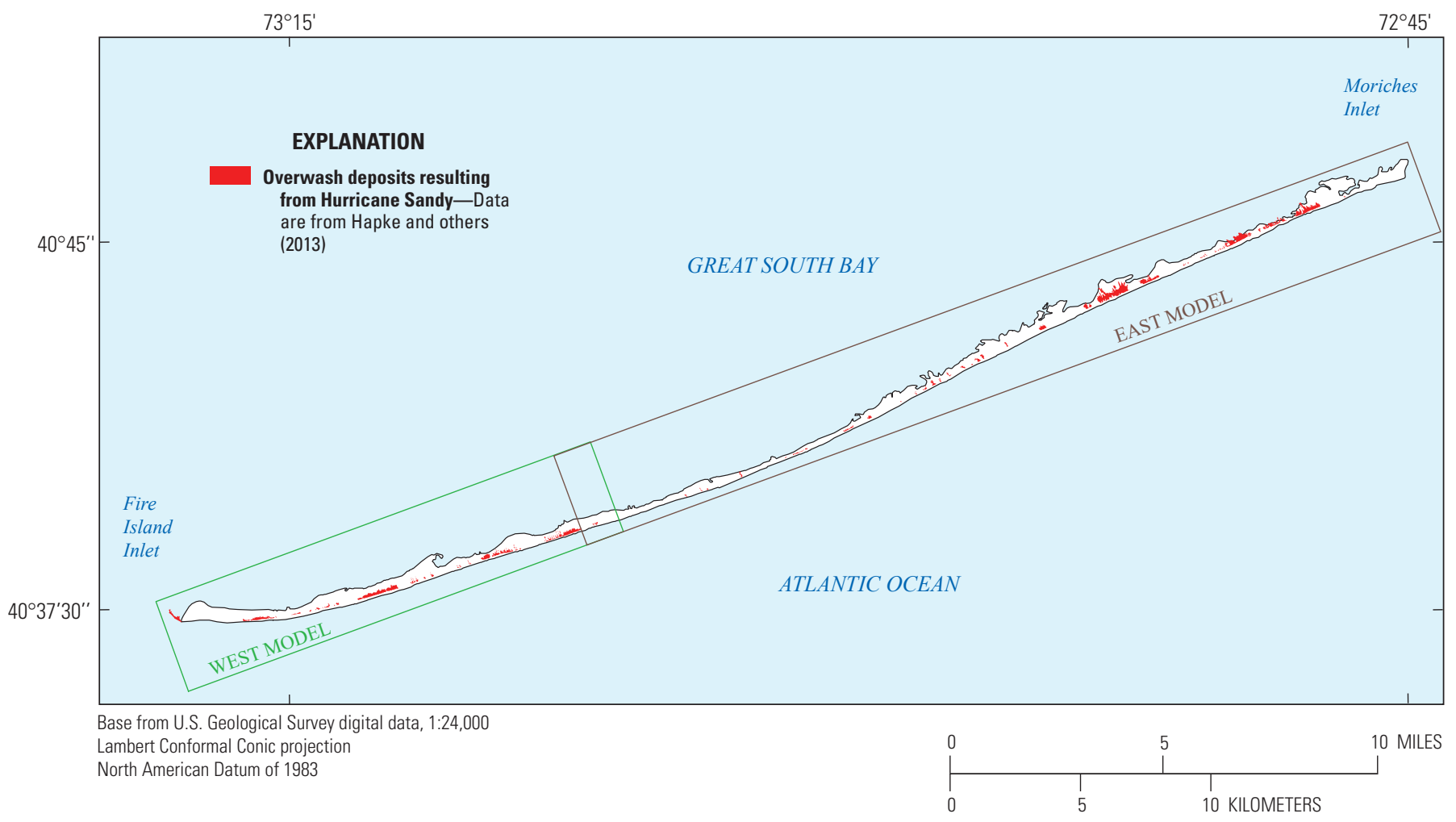

Figure 1.4. Map showing Hurricane Sandy overwash deposits on Fire Island, New York.

Table 1.1. Horizontal and vertical hydraulic conductivity values in meters per day for hydrogeologic units in the model of Fire Island, New York.

[Data are from Schubert (2010)]

\begin{tabular}{llclc}
\hline & \multirow{2}{*}{ Hydrogeologic unit } & \multicolumn{3}{c}{ Hydraulic conductivity } \\
\cline { 2 - 4 } & & Horizontal & Vertical & Ratio, horizontal to vertical \\
\hline Surficial Holocene units & Barrier island and shelf sands & 45 & 4.5 & $10: 1$ \\
& Peat deposits & 2 & 0.02 & $100: 1$ \\
& Seagrass beds & 4 & 0.04 & $100: 1$ \\
& Estuarine mud & 0.3 & 0.003 & $100: 1$ \\
\hline Lagoonal deposits & Western zone & 25 & 1 & $25: 1$ \\
& Eastern zone & 20 & 0.67 & $30: 1$ \\
\hline Upper outwash1 & & 30 & 1.5 & $20: 1$ \\
\hline "20-foot" clay1 & & 0.03 & 0.0003 & $100: 1$ \\
\hline Lower outwash & Upper zone & 20 & 0.67 & $30: 1$ \\
& Middle zone & 10 & 0.1 & $100: 1$ \\
& Lower zone & 3 & 0.03 & $100: 1$ \\
\hline
\end{tabular}

${ }^{1}$ Unit not subdivided into separate hydrologic and geologic units. 


\section{Recharge}

Recharge is represented as a specified-flux boundary at the water table, using five precipitation infiltration (recharge) zones assigned according to substrate and altitude and a geographic analysis of water supply and sewer systems (Schubert, 2010, fig. 27). Recharge rates of the SEAWAT model are generally applied to the SWI2 model but have been increased by 10 percent in areas where overwash occurred during Hurricane Sandy owing to death of plants buried by sand and corresponding decrease in transpiration. Recharge rates also varied from SEAWAT values during future hypothetical climate change scenarios.

\section{Evapotranspiration}

In emerging wetland areas where there may be discharge of water at the water table, the EVT package was applied on a cell-by-cell basis with the maximum evapotranspiration rate set to 0.001 meter per day $(\mathrm{m} / \mathrm{d})$ (volumetric flow rate per unit area, about 10 percent of average recharge rate for Fire Island). If the head in the cell with an evapotranspiration boundary is higher than the land surface, the evapotranspiration rate is set to the maximum value. If the head in the cell with an evapotranspiration boundary is lower than the land surface minus the evapotranspiration extinction depth of $0.1 \mathrm{~m}$, the evapotranspiration rate is set to zero. If the head in the cell with an evapotranspiration boundary is lower than the land surface but above land surface minus the evapotranspiration extinction depth, the evapotranspiration rate will be linearly interpolated between zero (at the land surface minus evapotranspiration extinction depth) and the maximum evapotranspiration rate (at the land surface).

In some cases of the steady-state, present-condition SWI2 model (baseline scenario), evapotranspiration boundary conditions are represented in wetland areas that are not represented in Schubert (2010) because of the finer scale used in the model in this report and changes to topography from Hurricane Sandy. During climate change scenarios, recharge and evapotranspiration may either increase or decrease.

\section{General-Head Boundaries}

General-head boundaries are used within estuaries and the ocean to represent the flow of water between the shallow aquifer and marine surface waters. Beyond the zone of overheight from wave setup and tidal pumping, water levels are lower in the ocean than in the back-barrier estuaries where levels generally increase with distance from inlets. Generalhead water levels increase during climate change scenarios.
For the SWI2 model, values for the general-head boundary (GHB) parameter are freshwater equivalent and calculated from the following: sea-surface altitudes given in the National Oceanic and Atmospheric Administration's VDatum tool (Yang and others, 2010), salinity simulated by SEAWAT (fig. 1.5; Schubert, 2010), bathymetry from SEAWAT updated using CoNED, and the sum of wave overheight and tidal pumping as generally represented in SEAWAT. The sum of wave overheight and tidal pumping was updated using CoNED bathymetry, including representation of the Old Inlet breach at about column 800 in the SWI2 model. When determining the sum of wave overheight and tidal pumping, a function of distance from the shoreline was constructed to linearly interpolate from the following altitude inflection points:

- shoreline: $+0.66 \mathrm{~m}$

- $100 \mathrm{~m}$ seaward of shoreline: $0.0 \mathrm{~m}$

- $200 \mathrm{~m}$ seaward of shoreline: $-0.085 \mathrm{~m}$

- $300 \mathrm{~m}$ seaward of shoreline: $0.0 \mathrm{~m}$

The GHB conductance parameter was calibrated for this study because there was no equivalent parameter in SEAWAT, which used a standard constant head/constant salinity boundary condition without conductance parameterization.

\section{Groundwater Withdrawals}

The model does not simulate public-supply withdrawal because all water-supply wells are screened within the underlying regional (unmodeled) aquifer system, below the Gardiners clay confining unit (fig. 1.5). However, supplementation of natural groundwater recharge by return flow is represented following the model from Schubert (2010).

\section{Model Calibration and Sensitivity Analysis Approach}

Calibration of the SWI2 model followed an approach determined by a consortium of national seashore studies (Fire Island, Assateague, and Sandy Hook) wherein parameters are adjusted and estimated using a combination of the UCODE_2005 inverse method (Poeter and others, 2005) and trial and error. Seashore models are calibrated to steady-state present-condition heads and freshwater/saltwater interface positions. Parameters were not adjusted to optimize the performance of models to simulate future scenario changes.

Owing to the thorough and validated calibration of the Fire Island SEAWAT model (Schubert, 2010), most parameters of the SWI2 model were set at SEAWAT values. However, 


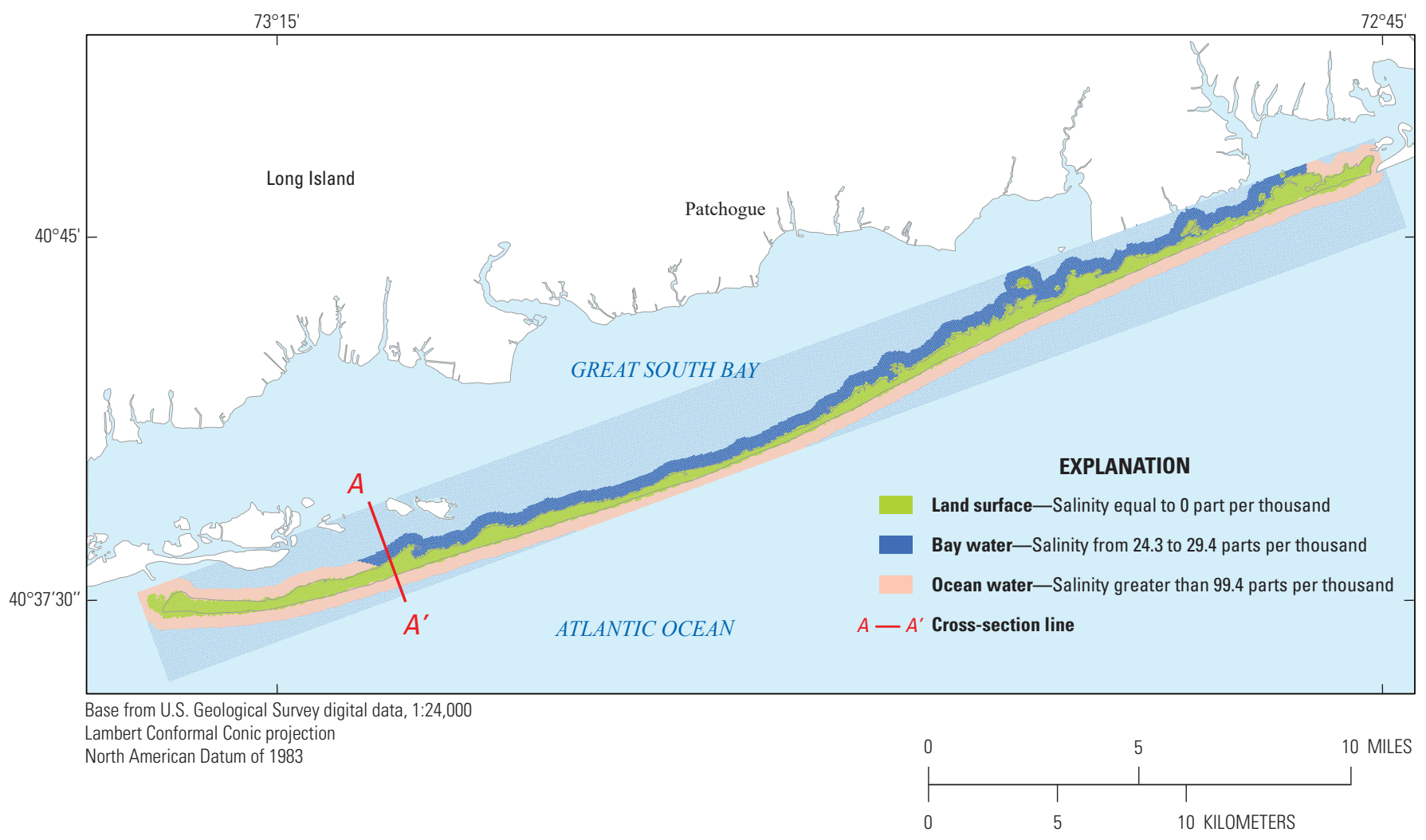

Figure 1.5. Sea floor salinity as simulated by the SEAWAT three-dimensional variable-density groundwater flow and transport model of Fire Island, New York. Salinity data are from Schubert (2010).

these parameters were analyzed using the UCODE_2005 method to determine calibration characteristics such as composite scaled sensitivity. Because of this analysis, there were a few additional SWI2 parameters to calibrate that were not found in the SEAWAT model; there were also some SEAWAT parameters not used in SWI2.

\section{Parameter Estimation}

The GHB conductance parameter, uniformly applied to all seafloors, was estimated through minimization of an objective function (sum of squared head residuals) using UCODE 2005. Convergence was attained with a final value of 3,897 square meters per day $\left(\mathrm{m}^{2} / \mathrm{d}\right)$ with 95 percent confidence that this value does not exceed about $8,000 \mathrm{~m}^{2} / \mathrm{d}$. Because of constraints of the SWI2 model, it was not possible to explicitly represent the offshore surface-water zone. Head observations are described in the following section.

Other SWI2 model parameters were not estimated but fixed at SEAWAT values from Schubert (2010). All model conductivity parameters were fixed at values established by Schubert (2010). The following boundary condition parameters were estimated: GHB specific conductances for eastern, western, and ocean zones, an evapotranspiration term, and a drain conductance. They were changed to minimize head residuals and resulted in an unbiased calibration (fig. 1.6). The greatest negative residuals (simulated head greater than observed) are at observation wells S125370 and S125983 (fig. 4, main text); the greatest positive residuals are at observation wells S124400 and S125385. Owing to the significantly faster runtimes (about 1 minute for the SWI2 model compared with 4 hours for the SEAWAT model) and increased robustness to parameter variation, the UCODE_2005 software (Poeter and others, 2005) could be applied in the analysis of the SWI2 model calibration.

\section{Observations Used in Model Calibration}

Density-dependent heads as observed in the field or simulated by the SEAWAT model may be converted to freshwater equivalent heads, such as those simulated by the SWI2 model (figs. 1.6 and 1.7; table 1.2). SWI2 heads are slightly lower than SEAWAT and observed heads. However, when SEAWATsimulated density-dependent heads are converted to freshwater equivalent heads through use of the simulated density distribution, the mean residual becomes positive, indicating slightly higher simulated heads than observed heads and an expected buoyancy correction. As discussed by Post and others (2007), 
even subtle density variations are a key factor in determining hydraulic head gradients, and all head measurements should be carried out in conjunction with measurements of electrical conductivity. The density can then be estimated from simple relations between density and salinity.

SEAWAT and SWI2 model results may be compared along cross-section $A-A^{\prime}$ (fig. 1.6). In the region above the SWI2-simulated freshwater/saltwater interface and in the freshwater zone of the SEAWAT simulation, heads are directly comparable and water flows orthogonally to head contours. Similar convective flow patterns and a shifting of the divide of the freshwater system from the spine of the island southward toward the ocean are present (vectors of the SEAWAT section are not scaled to magnitude). The well couplet in the center of cross-section $A-A^{\prime}$ is near the groundwater divide but is several model cells closer to the ocean shore than the bay shore. The observed hydraulic gradient of wells S125986 (upper) and S126753 (lower) is zero; however, the location of this couplet near the groundwater divide of the section suggests a slight downward gradient. The variable-density head gradient simulated by SEAWAT is 0.005847 meter per meter $(\mathrm{m} / \mathrm{m})$ downward, and the freshwater equivalent SWI2 gradient is 0.00014 $\mathrm{m} / \mathrm{m}$ upward. Given the vertical hydraulic conductivity of 1 $\mathrm{m} / \mathrm{d}$, the Darcy velocities are $0.005847 \mathrm{~m} / \mathrm{d}$ for the SEAWAT model and $0.00014 \mathrm{~m} / \mathrm{d}$ for the SWI2 model.

The depth to the mean contaminant level for salinity, set at 250 parts per million chloride, was selected from the electromagnetic induction logs of many wells from Schubert (2010); these values were qualitatively compared with SWI2 simulated values (table 1.3). The mean difference between the depth to mean contaminant level and the interface depth in the SWI2 model was about $1.7 \mathrm{~m}$ owing to the greater salinity (29 parts per thousand) at the SWI2 boundary than the mean contaminant level boundary. Within saline parts of figure 1.6, heads are not directly comparable, as described earlier in this section. In the deep saline region of the SEAWAT simulation, vectors are shown but not scaled to magnitude, but flow is nearly stagnant.

\section{Sensitivity Analyses}

UCODE_2005 was used to calculate the composite scaled sensitivity of all hydraulic conductivity parameters (fig. 1.8). Composite scaled sensitivity may be used to compare the amount of information provided by different types of parameters; model simulation results will be more sensitive to parameters with large composite scaled sensitivity. According to composite scaled sensitivity analysis, the model results are most sensitive to horizontal hydraulic conductivities of two upper zones. The most sensitive vertical hydraulic conductivity parameters are for peat, shelf sands, and lagoonal areas. Model results are moderately sensitive to calibrated GHB conductance and evapotranspiration parameters.

UCODE_2005 identified the horizontal and vertical estuarine mud hydraulic conductivity parameters as correlated at greater than 85 percent, indicating they may not be estimated individually. 


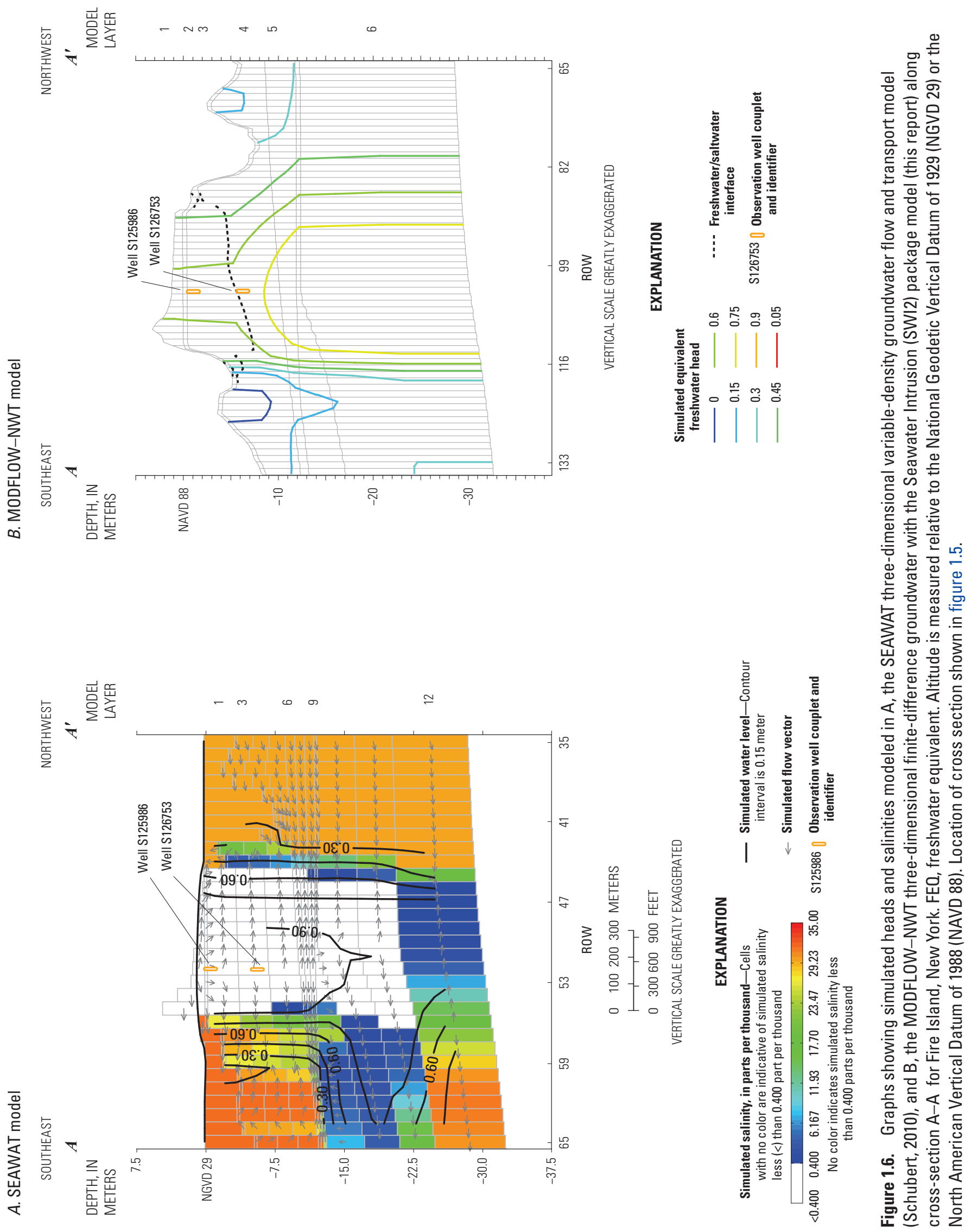


Table 1.2. Model-simulated water-level targets for Fire Island, New York.

[SEAWAT is three-dimensional variable-density groundwater flow and transport model from Schubert (2010); SWI2 is the MODFLOW-NWT threedimensional finite-difference groundwater with the Seawater Intrusion (SWI2) package model prepared for this report. All head values are converted to meters above National Geodetic Vertical Datum of 1929. Residual is simulated minus observed head. FEQ, freshwater equivalent; XX, not applicable]

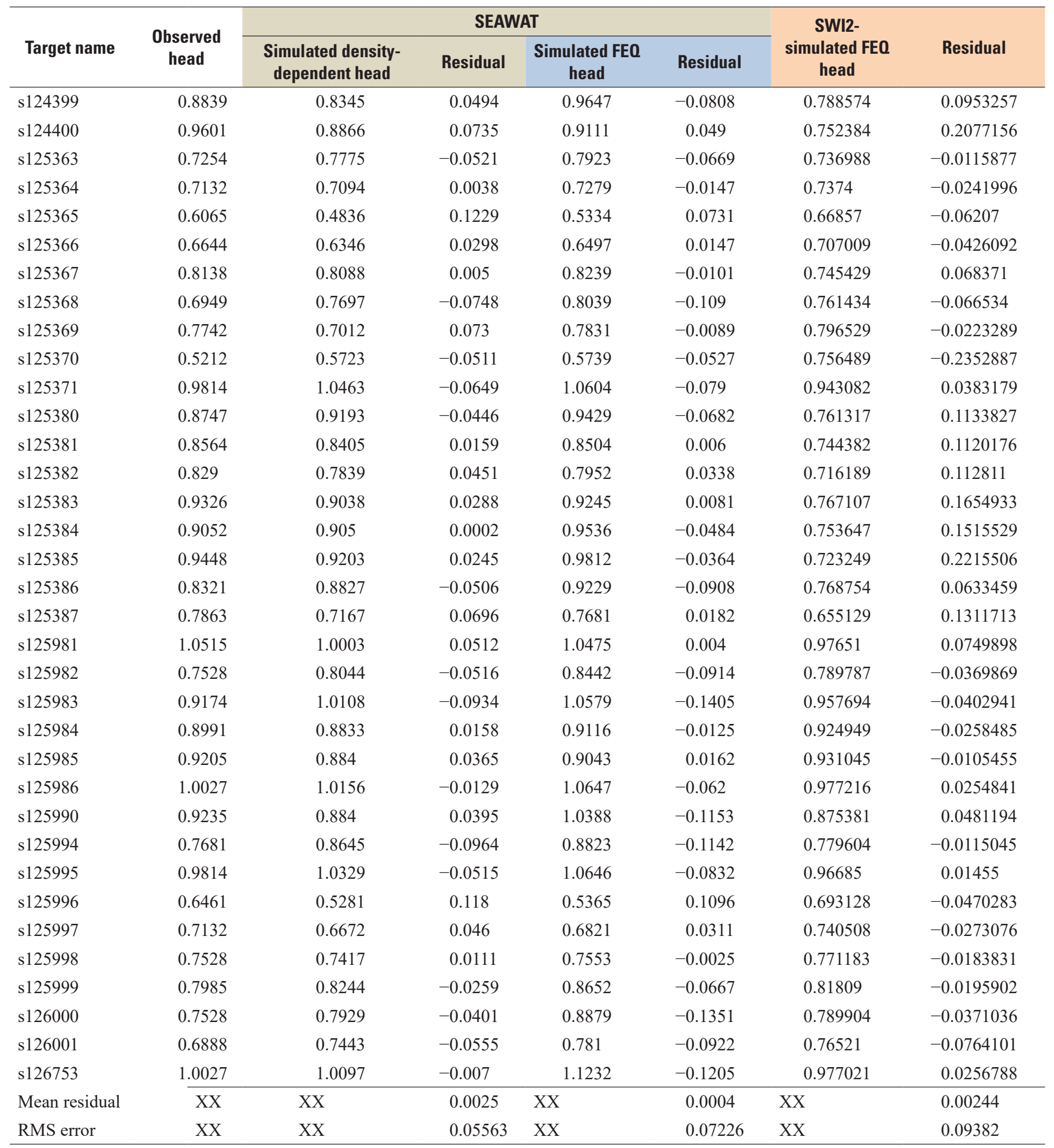




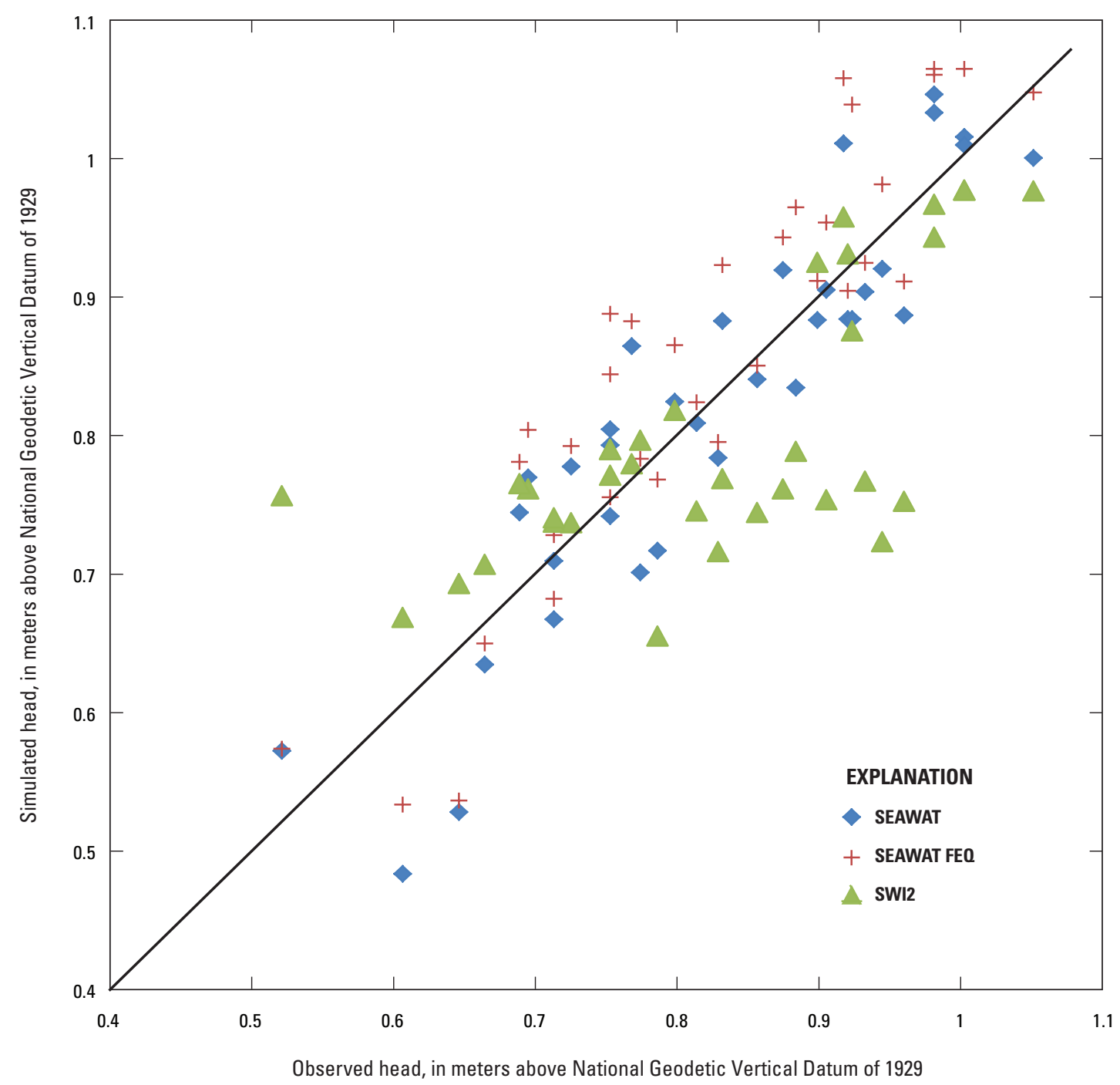

Figure 1.7. Graph showing observed heads and simulated heads of the SEAWAT three-dimensional variable-density groundwater flow and transport model (Schubert, 2010), and the MODFLOW-NWT three-dimensional finite-difference groundwater with the Seawater Intrusion (SWI2) package model (this report) for Fire Island, New York. FEQ, freshwater equivalent. Altitude is measured relative to the National Geodetic Vertical Datum of 1929 (NGVD 29). 
Table 1.3. Freshwater/saltwater interface simulation for Fire Island, New York.

[Data are for the MODFLOW-NWT three-dimensional finite-difference groundwater with the Seawater Intrusion (SWI2) package model. Head and altitude values are converted to meters (m) above National Geodetic Vertical Datum of 1929 (NGVD 29). FEQ, freshwater equivalent; MCL, mean contaminant level; residual, simulated minus observed head; XX, not applicable]

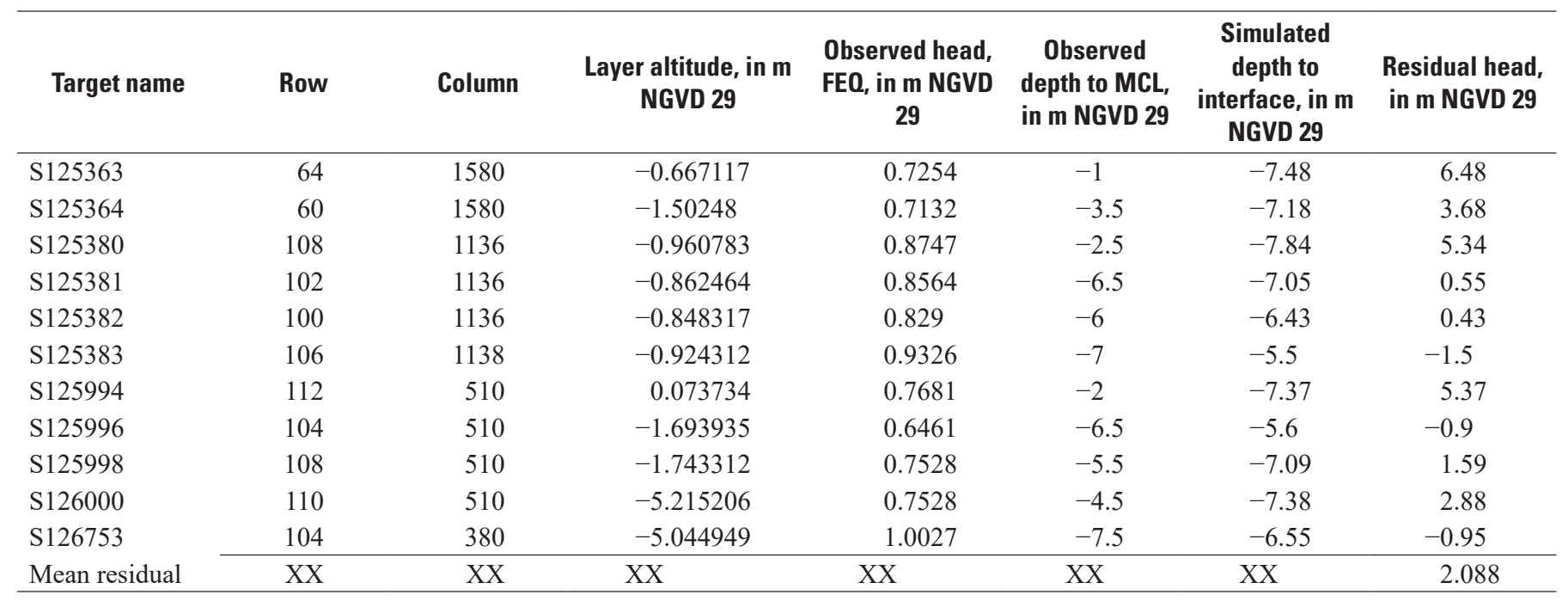

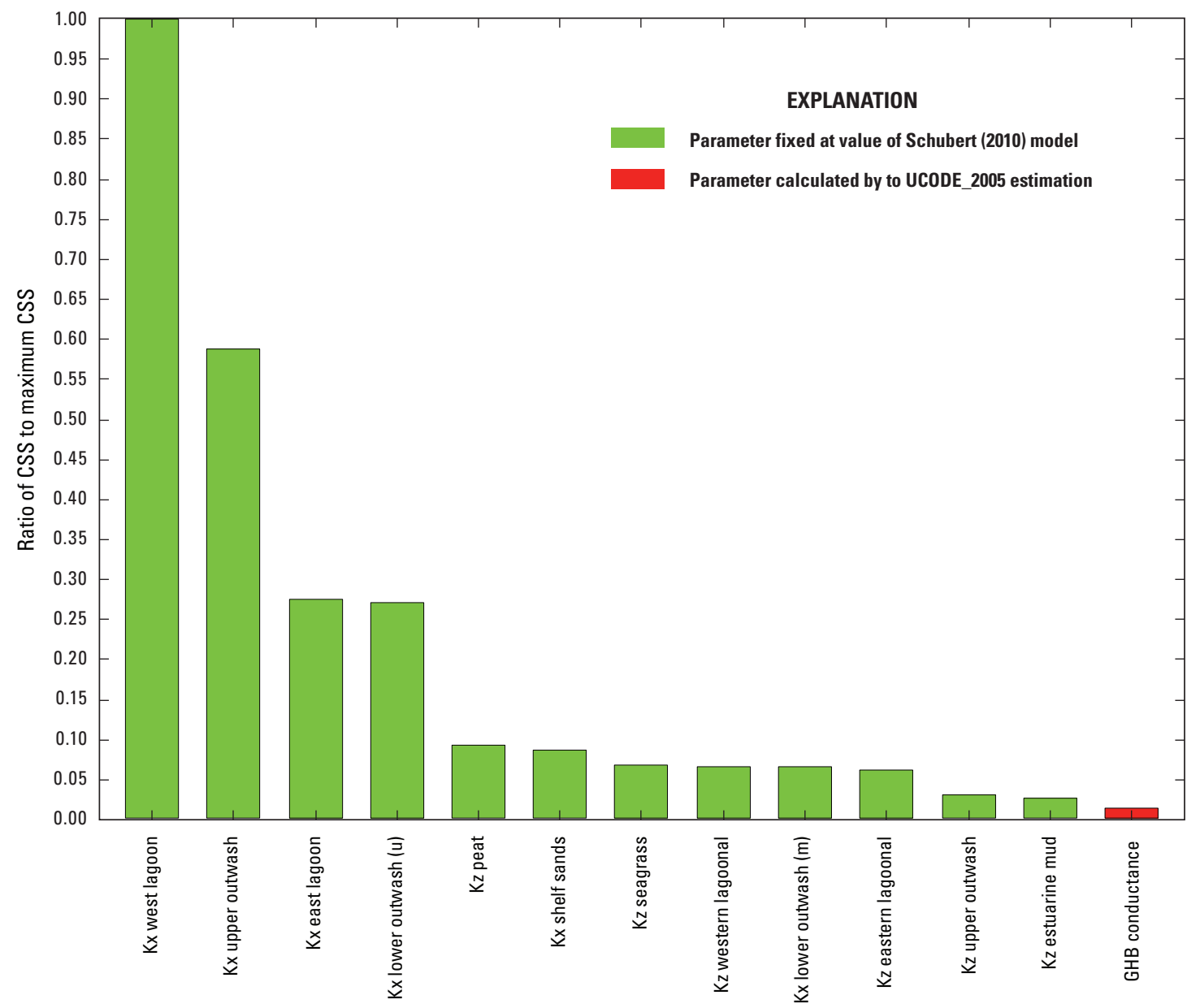

Figure 1.8. Graph showing composite scaled sensitivities of most sensitive parameters, Fire Island, New York. CSS, composite scaled sensitivity; Kx, horizontal hydraulic conductivity; Kz, Vertical hydraulic conductivity; (I), lower; GHB, general head boundary. 


\section{References Cited}

Bakker, M., Schaars, F., Hughes, J.D., Langevin, C.D., and Dausman, A.M., 2013, Documentation of the seawater intrusion (SWI2) package for MODFLOW: U.S. Geological Survey Techniques and Methods, book 6, chap. A46, 47 p. [Also available at https://doi.org/10.3133/tm6A46.]

Buxton, H.T., and Smolensky, D.A., 1999, Simulation of the effects of development of the ground-water flow system of Long Island, New York: U.S. Geological Survey Water Resources Investigations Report 98-4069, 57 p. [Also available at https://doi.org/10.3133/wri984069.]

Danielson, J.J., Poppenga, S.K., Brock, J.C., Evans, G.A., Tyler, D.J., Gesch, D.B., Thatcher, C.A., and Barras, J.A., 2016, Topobathymetric elevation model development using a new methodology - Coastal national elevation database: Journal of Coastal Research, v. 76, no. special issue, p. 75-89.

Hapke, C.J., Brenner, O., Hehre, R., and Reynolds, B.J., 2013, Coastal change from Hurricane Sandy and the 2012-13 winter storm season-Fire Island, New York: U.S. Geological Survey Open-File Report 2013-1231, 37 p. [Also available at https://doi.org/10.3133/ofr20131231.]

Langevin, C.D., Thorne, D.T., Jr., Dausman, A.M., Sukop, M.C., and Guo, W., 2007, SEAWAT version 4-A computer program for simulation of multi-species solute and heat transport: U.S. Geological Survey Techniques and Methods, book 6, chap. A22, 39 p. [Also available at https://doi.org/ 10.3133/tm6A22.]

McClymonds, N.E., and Franke, O.L., 1972, Watertransmitting properties of aquifers on Long Island, New York, chap. E of Hydrology and some effects of urbanization on Long Island: U.S. Geological Survey Professional Paper 627-E, 24 p., 3 pls. [Also available at https://doi.org/ $10.3133 /$ pp627E.]

Niswonger, R.G., Panday, S., and Ibaraki, M., 2011, MODFLOW-NWT, a Newton formulation for MODFLOW-2005: U.S. Geological Survey Techniques and Methods, book 6, chap. A37, 44 p. [Also available at https://doi.org/10.3133/tm6A37.]
Poeter, E.P., Hill, M.C., Banta, E.R., Mehl, S., and Christensen, S., 2005, UCODE_2005 and six other computer codes for universal sensitivity analysis, calibration, and uncertainty evaluation: U.S. Geological Survey Techniques and Methods, book 6, chap. A11, 283 p. [Also available at https://doi.org/10.3133/tm6A11.]

Post, V., Kooi, H., and Simmons, C., 2007, Using hydraulic head measurements in variable-density ground water flow analyses: Ground Water, v. 45, no. 6, p. 664-671.

Schubert, C.E., 2010, Analysis of the shallow groundwater flow system at Fire Island National Seashore, Suffolk County, New York: U.S. Geological Survey Scientific Investigations Report 2009-5259, 107 p. [Also available at https://doi.org/10.3133/sir20095259.]

Smolensky, D.A., Buxton, H.T., and Shernoff, P.K., 1989, Hydrogeologic framework of Long Island, New York: U.S. Geological Survey Hydrologic Investigations Atlas 709, scale 1:250,000, 3 sheets.

U.S. Geological Survey, 2016a, ModelMuse version 3.8.1: U.S. Geological Survey groundwater software, accessed March 29, 2017, at https://water.usgs.gov/nrp/gwsoftware/ ModelMuse/ModelMuse.html.

U.S. Geological Survey, 2016b, MODFLOW and related programs: U.S. Geological Survey groundwater information, accessed March 29, 2017, at https://water.usgs.gov/ogw/ modflow/.

U.S. Geological Survey, [undated], Coastal national elevation database (CoNED) applications project: U.S. Geological Survey coastal changes and impacts, accessed March 29, 2017, at https://www.usgs.gov/core-science-systems/eros/ coned.

Winston, R.B., 2009, ModelMuse-A graphical user interface for MODFLOW-2005 and PHAST: U.S. Geological Survey Techniques and Methods, book 6, chap. A29, 52 p., accessed June 6, 2016, at https://doi.org/10.3133/tm6A29.

Yang, Z., Myers, E.P., Wong, A.D., and White, S.A., 2010, VDatum for Great South Bay, New York Bight and New York Harbor-Tidal datums, marine grids, and sea surface topography: National Oceanic and Atmospheric Administration Technical Memorandum NOS CS 21, 55 p. 

For more information, contact:

Director, New York Water Science Center

U.S. Geological Survey

425 Jordan Road

Troy, NY 12180-8349

or visit our website at

https://www.usgs.gov/centers/ny-water

Publishing support provided by the

West Trenton Publishing Service Center. 

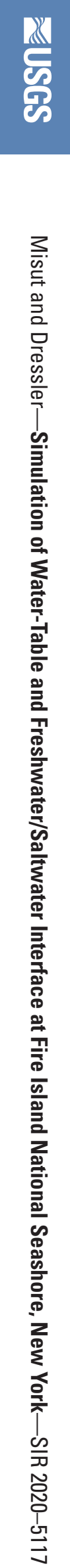